
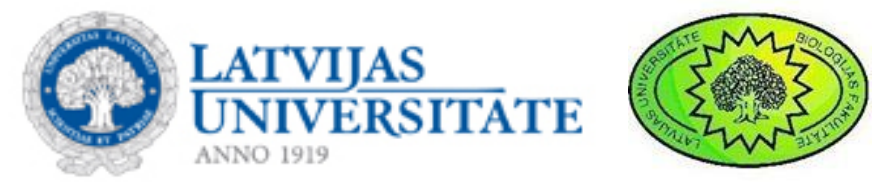

“LATVIJAS ŪDEṆU VIDES PĒTĪJUMI UN AIZSARDZĪBA"

LU 73. Zinātniskā konference

Bioloǵijas fakultāte, Hidrobioloǵijas katedra

Referātu tēžu krājums

Rīga, Latvijas Universitāte. 2015.

CLatvijas Universitāte, 2015.

CIvars Druvietis, vāka foto. 


\section{SATURS}

FITOBENTOSA INDIKATORU KVALITĀTES KLAŠU ROBEŽVĒRTİBU IZSTRĀDE LATVIJAS PIEKRASTEI_MADARA ALBERTE. . .6

ŪDENS CAURSPĪDĪBAS IZMAIṆAS RĪGAS JŪRAS LİCī PĒDĒJOS 50 GADOS VIESTURS BĒRZIṆŠ .8 CEḶOTĀJZIVJU POPULĀCIJU STĀVOKLIS UN TĀ UZLABOŠANAS IESPĒJAS JUGLAS BASEINA UPĒS JĀNIS BIRZAKS, KASPARS ABERSONS, MĀRIS STRŪG̣IS, JĀNIS BAJINSKIS.

BALTIJAS JŪRAS PIEKRASTES ZIVJU SABIEDRĪBAS IZMAIṆAS PĒDĒJO GADU LAIKĀ... LAURA BRIEKMANE, DIDZIS USTUPS, ELĪNA KNOSPIN̦A, ĒVALDS URTĀNS.

PROTOZOOPLANKTONS KĀ POTENCIĀLS INDIKATORS PILSĒTVIDES HIDROEKOSISTĒMĀS....... LINDA BUHOLCE, ELMİRA BOIKOVA, VITA LĪCĪTE, ULDIS BOTVA

ZIVJU MAZUḶU BAROŠANĀS EKOLOG̣IJA BURTNIEKU EZERĀ 2014. GADA VASARAS SEZONĀ.. MARTA DIEVIṆA, MATITSS ŽAGARS.

DEMONSTRĀCIJU SAIMNIECĪBAS „LIELKRŪZES” VIRSZEMES ŪDEṆU KVALITĀTES NOVĒRTĒJUMS DĀ VIS GRUBERTS, JANA PAIDERE.

LATVIJAS UN LIETUVAS UPJU HIDROMORFOLOG̣ISKĀ NOVĒRTĒJUMA SALĪDZINĀJUMS_JOLANTA JĒKABSONE34 RESNVĒDERA PURVUSPĀRES LEUCORRHINIA CAUDALIS (ODONATA: LIBELLULIDAE) IZPĒTE UN AIZSARDZĪBA LATVIJĀ_MĀRTIN̦Š KALNIN̦Š.

FITOPLANKTONA INDIKATORU KLAŠU ROBEŽVĒRTĪBU IZSTRĀDE LATVIJAS PIEKRASTEI ATIS LABUCIS, IEVA BĀRDA, IVETA JURGENSONE.

VIENDIENIŤ̌U SUGU IZPLATĪBA VENTAS UN LIELUPES BASEINU APGABALOS SAISTĪBĀ AR ŪDENS FIZIKĀLIḲIMMISKAJIEM PARAMETRIEM DĀVIS OZOLIN̦Š, AGNIJA SKUJA, ELGA PARELE, ILGA KOKORĪTE, JOLANTA JËKABSONE, LAURA GRĪNBERGA

ZIVJU SASTOPAMĪBA LATVIJAS ŪDEṆOS BALTIJAS JŪRĀ UN RĪGAS JŪRAS LĪCĪMĀRIS PLIKŠS.

ZOOBENTOSA SABIEDRĪBU STRUKTURĀLĀS IZMAIṆAS UPJU MELIORATT̄VO DARBU VEIKŠANAS PROCESĀ ARKĀDIJS POPPELS.

GLIEMEṆU MYTULUS TROSSULUS AUDZĒŠANAS IESPĒJAS LATVIJAS PIEKRASTĒ INGRĪDA PURIṆA, IEVA BĀRDA

STORES SASTOPAMĪBAS UN REINTRODUKCIJAS VĒSTURE LATVIJĀ SANTA PURVIṆA, RUTA MEDNE, MĀRCIS ZIN̦G̦IS. 
SEŠU DAŽĀDU JONU ŠKIIIDUMU EKOTOKSICITĀTE, IZMANTOJOT DAPHNIA MAGNA, VIBRIO FISCHERI UN DANIO RERIO EKOTOKSICITĀTES TESTU IEVA PUTNA

ZOOPLANKTONA UN REṆGGES CLUPEA HARENGUS L. TELPISKAIS SADALĪJUMS UN SAVSTARPĒJĀ IETEKME

RĪGAS LĪCĪ (BALTIJAS JŪRĀ) GUNTA RUBENE, IVARS PUTNIS, GUNTARS STRODS

VENTAS UN LIELUPES BASEINU UPJU EKOLOG̣ISKĀ STĀVOKḶA NOVĒRTĒJUMS PĒC BIOLOG̣ISKAJIEM, HIDROMORFOLOG̣ISKAJIEM UN FIZIKĀLI ḲIMMISKAJIEM PARAMETRIEM AGNIJA SKUJA, DĀVIS OZOLIN̦Š, JOLANTA JĒKABSONE, ILGA KOKORITTE, LAURA GRITNBERGA UN ELGA PARELE.

SVEŠO SUGU MONITORINGS BALTIJAS JŪRAS OSTĀS SOLVITA STRĀḲE, IEVA BĀRDA, ASTRA LABUCE, VIKTORS

PĒRKONS, SVETLANA ROMANOVIČA. .80

SĀNPELDES KĀ RĪGAS LĪČA SEDIMENTU KVALITĀTES INDIKATORS EVITA STRODE, MAIJA BALODE .82

SIVERA EZERA DABAS VĒRTĪBAS SMALKĀS UN LOKANĀS NAJĀDAS (NAJAS TENUISSIMA, N. FLEXILIS) ATRADṆU AIZSARGĀŠANAS KONTEKSTĀ UVIS SUŠKO.

PELDOŠĀ MONITORINGA STACIJA KĀ PAMATS PASTĀVĪGAM HIDROBIOLOG̣ISKAJAM UN HIDROḲIMMISKAJAM MONITORINGAM ENGURES EZERĀ ROBERTS ŠILIN̦Š

MIR INDEKSA (MACROPHYTE INDEX FOR RIVERS) IZMANTOŠANA LATVIJAS UPJU EKOLOG̣ISKĀS KVALITĀTES NOTEIKŠANĀ LINDA UZULE

MAKROFĪTU VEG̣ETĀCIJAS RAKSTUROJUMS L̦OTI SEKLOS UN SEKLOS BRŪNŪDENS EZEROS LATVIJĀ LAUMA VIZULE - KAHOVSKA 100

ATLANTIJAS STORES (ACIPENSER OXYRINCHUS) RESURSU PAPILDINĀŠANAS REZULTĀTI PIRMAJĀ GADĀ PĒC IZLAIŠANAS MĀRCIS ZIN̦G̣IS, RUTA MEDNE, SANTA PURVIN̦A 


\title{
FITOBENTOSA INDIKATORU KVALITĀTES KLAŠU ROBEŽVĒRTĪBU IZSTRĀDE LATVIJAS PIEKRASTEI
}

\author{
Madara ALBERTE \\ Latvijas Hidroekologijas institūts, Daugavgrīvas 8, Rīga LV-1048 \\ *e -pasts: madara.alberte@lhei.lv
}

Saskaṇā ar ES Ūdens Struktūrdirektīvas (2000/60/EK) prasībām izveidot un interkalibrēt virszemes ūdensobjektu novērtēšanas bioloğisko elementu metodiku līdz 2016. gadam, 2014. gadā tika apkopots un pabeigts darbs pie fitobentosa indikatoru testēšanas un pielāgošanas Latvijas piekrastes ūdeniiem. Tā rezultātā tika izstrādātas ekologiiskās kvalitātes klašu robežvērtības trim fitobentosa izplatības maksimālā dziḷuma indikatoriem.

Fitobentosa sugu izplatības maksimālais dziḷums ir visplašāk izmantotais fitobentosa indikators Baltijas jūras valstīs, galvenokārt vēsturisko datu esamības un relatīvi vienkāršākās metodoloǵijas dēḷ. No fitobentosa indikatoriem šobrīd šis ir arī piemērotākais indikators iekḷaušanai HELCOM core jeb pamata indikatoru sarakstā (CORESET II, 2015). Izmantojot LU Biologijas institūta un Latvijas Hidroekologijas institūta datus, kas aptver laika posmu no 1999. līdz 2013. gadam, Rīgas līcim tika analizēta līča nozīmīgākās sugas F. vesiculosus un kopējās makroveǵetācijas izplatības dziḷumu saistība ar dažādiem eitrofikācijas spiediena rādītājiem. Statistiski būtiska saistība tika konstatēta ar ūdens

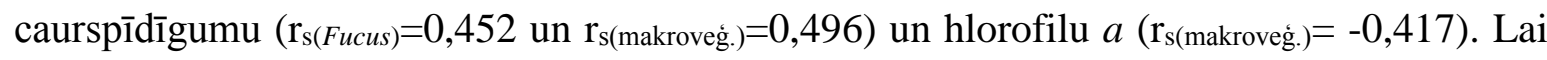
izveidotu vienotu metodi Rīgas līcim, abi šie indikatori tika apvienoti indeksā PEQI (Phytobenthos Ecological Quality Index). Atklātajā piekrastē F. lumbricalis maks. dziḷuma indikatora funkcionēšana tika testēta, izmantojot kopēju Latvijas un Lietuvas nacionālo monitoringu datu kopu (2003.-2013. g.). - Kuršu lagūnas ieplūdes dēl eitrofikācijas ietekme daudz labāk atklājās reǵionālā mērogā. Būtisku ietekmi uz $F$. lumbricalis dziḷuma izplatību uzrādīja ūdens caurredzamība un kopējais fosfors $\left(\mathrm{r}_{\mathrm{s}(\mathrm{Seki})}=0,46\right.$ un $\left.\mathrm{r}_{\mathrm{s}(\mathrm{Pkop})}=-0,42\right)$. References stāvokḷa noteikšanai tika izmantoti pieejamie vēsturiskie dati (Skuja, 1924; Martin, 1999; Kireeva, 1960; Korolev, Fetter, 2003), GES robežas noteikšanā - mērenā atkāpe no references stāvokḷa jeb $\mathrm{EQR}=0,75$. 
Darbs veikts LVAF finansēta projekta „ES Ūdens Struktūrdirektīvas 2000/60/EK īstenošana Latvijas piekrastes un pārejas ūdeṇos (Baltijas jūra): bioloğisko kvalitātes elementu (fitoplanktona, makrofitu, bentosa bezmugurkaunieku) interkalibrācija un testēšana (zivis)" ietvaros.

\section{Izmantotā literatūra:}

CORESET II, 2015. HELCOM projekta CORESET II bentosa ekspertu sanāksmju iekšējie nepublicētie materiāli.

Kireeva M. 1960. Distribution and biomass of marine algae in the Baltic Sea. Trudi WNIRO, 42:195-205. (Krievu valodā).

Korolev A., Fetter M. 2003. The mapping of benthic biocenoses in the coastal zone of Latvia. ICES CM2000/T, $11 \mathrm{pp}$.

Martin G. 1999. Distribution of phytobenthos biomass in the Gulf of Riga (1984-1991). Hydrobiologia, 393:181-190.

Skuja H. 1924. Mērsraga - Ragaciema piekrastes algges. Acta Univ. Latviensis, 10:337-392. 


\title{
ŪDENS CAURSPĪDĪBAS IZMAIN̦AS RĪGAS JŪRAS LĪCĪ PĒDĒJOS 50 GADOS Viesturs BĒRZIN̦Š
}

\author{
BIOR Zivsaimniecības departamenta Jūras laboratorija, \\ *e-pasts: Viesturs.Berzins@bior.gov.lv
}

Ūdens caurspīì̄gums ir vizuāli nosakāms parametrs, un tā sastāv no divām daḷām: 1) ūdens caurspīdības dziḷuma pēc Seki diska rādījumiem, ko nosaka vizuāli, 2) ūdens krāsas, ko arī nosaka vizuāli. Abas caurspīdības daląas ir atkarīgas no apgaismojuma, un proti, tās ir nosakāmas vien̄̄gi apstākḷ,os, kad Saule ir virs horizonta, tās ir subjektīvas, respektīvi, ūdens caurspīdības un krāsas parametri ir atkarīgi no novērotāja individuālajām īpatnībām. Ūdens caurspīdība Rīgas jūras līcī ir pētīta vairākkārt, bet piln̄̄ga tās analīze nav sniegta (Захарченко H.E.,1962; Berzinsh V., 1995).

Laikā no 1963. gada līdz 2014. gadam ūdens caurspīdības novērojumi Rīgas jūras līcī ir veikti aptuveni 185 okeanogrāfiskajās stacijās (skatīt 1. attēlu).

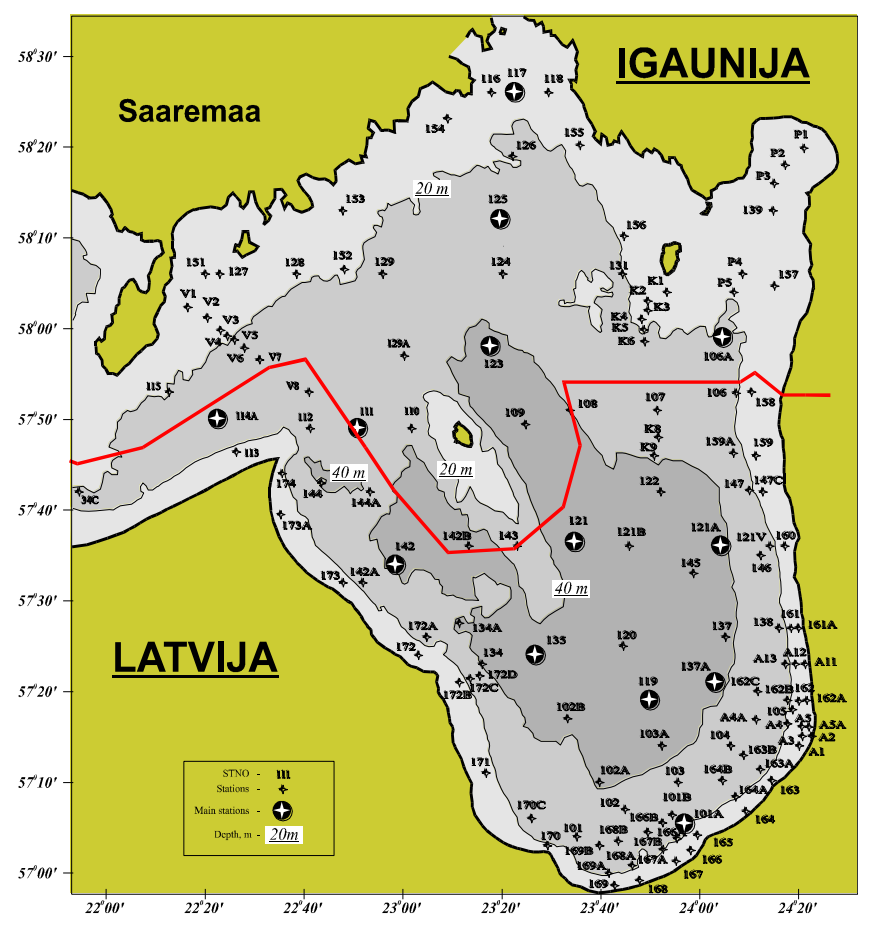

1. attēls. Okeanogrāfisko novērojumu stacijas Rīgas jūras līcī laikā no 1963. līdz 2014. gadam. 
Ūdens caurspīdības dinamika Rīgas jūras līcī šajā laikā (1963. - 2014.) uzrāda to, ka caurspīdība laika gaitā būtiski samazinās (skatīt 2. attēlu).

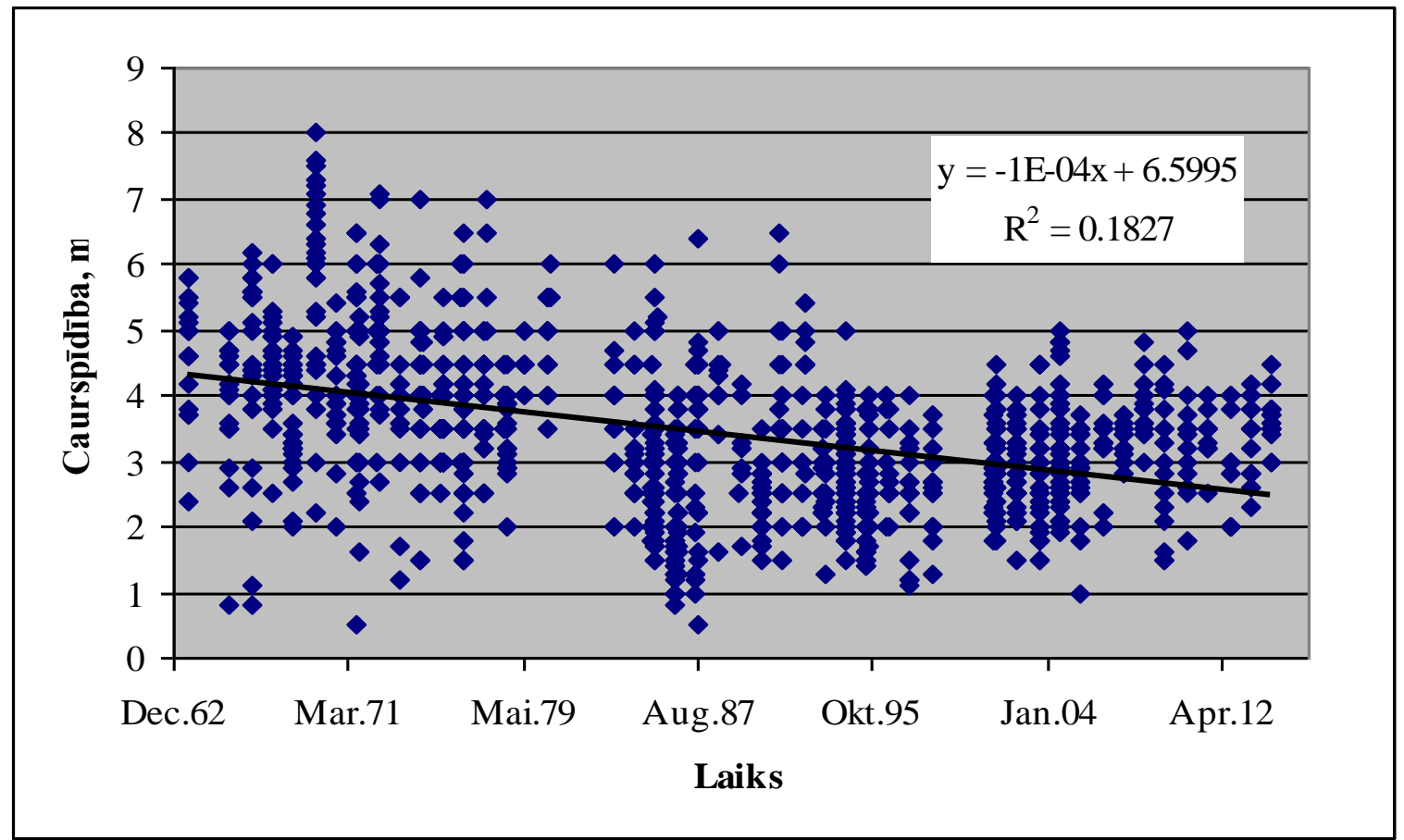

2. attēls. Ūdens caurspīdības dinamika Rīgas jūras līcī laikā no 1963. līdz 2014. gadam.

Analizējot visus datus pēdējos 50 gados, jāsecina, ka ūdens caurspīdības un ūdens krāsas dinamika šajā laika periodā sezonāli mainās ḷoti maz, piemēram, caurspīdība svārstās no 2,4 m līdz 3,9 m, pie kam, šīm svārstībām nav izteikts sezonāls raksturs, bet ūdens krāsa (pēc krāsu skalas SČV) mainās tikai no 14 līdz 16 (skatīt 1. tabulu). 
1. tabula. Ūdens caurspīdības un krāsas sezonalitātes dinamika Rīgas jūras līcī laikā no 1963. līdz 2014. gadam.

\begin{tabular}{|l|l|l|l|l|l|l|l|l|l|l|l|l|}
\hline Mēnesis & I & II & III & IV & V & VI & VII & VIII & IX & X & XI & XII \\
\hline Novērojumi & 26 & 69 & 20 & 253 & 1170 & 327 & 350 & 998 & 234 & 268 & 117 & 35 \\
\hline Caurspīdība & 3.3 & 2.4 & 3.3 & 2.6 & 3.0 & 3.9 & 3.1 & 3.6 & 3.6 & 3.4 & 2.7 & 3.2 \\
\hline Mēnesis & I & II & III & IV & V & VI & VII & VIII & IX & X & XI & XII \\
\hline Krāsa, Nr. & 15 & 14 & 16 & 16 & 16 & 14 & 14 & 14 & 14 & 14 & 15 & 16 \\
\hline
\end{tabular}

Lai pārbaudītu ūdens caurspīdības tendences sezonālajā aspektā, aprēḳināti daži ūdens caurspīdības statistiskie parametri dažādos laika periodos, un konstatēts, ka ciešākā sakarība starp ūdens caurspīdības dziḷumu un laiku ir vērojama vasaras vidū, laikā no jūlija līdz augustam (skatīt 2 . tabulu).

2. tabula. Ūdens caurspīdības sezonālās izmaiņas Rīgas jūras līcī laikā no 1963. līdz 2014. gadam.

\begin{tabular}{|l|l|l|l|l|l|}
\hline Periods & $\begin{array}{l}\text { Janvāris- } \\
\text { Decembris }\end{array}$ & $\begin{array}{l}\text { Aprīlis- } \\
\text { Novembris }\end{array}$ & $\begin{array}{l}\text { Maijs- } \\
\text { Oktobris }\end{array}$ & $\begin{array}{l}\text { Jūnijs- } \\
\text { Septembris }\end{array}$ & $\begin{array}{l}\text { Jūlijs- } \\
\text { Augusts }\end{array}$ \\
\hline Novērojumi & 3867 & 3717 & 3345 & 1909 & 1348 \\
\hline $\begin{array}{l}\text { Determinācijas koeficients } \\
\left(\mathrm{R}^{2}\right)\end{array}$ & 0.1061 & 0.1039 & 0.1092 & 0.1592 & 0.1827 \\
\hline Korelācijas koeficients (R) & -0.326 & -0.322 & -0.330 & -0.399 & $\mathbf{- 0 . 4 2 7}$ \\
\hline
\end{tabular}

Samērā voluntāri sadalot visu vasaras novērojumu rindu divās daḷās, un proti, laika periodā no 1963. gada līdz 1993. gadam, un laika periodā no 1994. gada līdz 2014. gadam, varam konstatêt, ka pirmajā periodā vērojama būtiska ūdens caurspīdības samazināšanās, bet otrajā periodā - vērojama neliela ūdens caurspīdības palielināšanās (skatît 3. tabulu). 
Sadalot visus vasaras (jūlijs - augusts) novērojumus pēc dziḷumu zonām, un proti, piekrastes zona ar kopējo dziḷumu aptuveni līdz 25 metriem, un dziḷā zona ar kopējo dziḷumu lielāku par 25 metriem, varam konstatēt, ka laika periodā no 1963. līdz 1993. gadam piekrastes zonā ūdens caurspīdības samazināšanās ir straujāka nekā dziḷajā zonā, bet laika periodā no 1994. līdz 2014. gadam ūdens caurspīdības palielināšanās ir aptuveni vienāda gan piekrastes zonā, gan dziḷajā zonā (skatīt 3 . tabulu).

3. tabula. Ūdens caurspīdības izmaiņas vasarā (jūlijā un augustā) Rīgas jūras līcī dažādos periodos un dziḷuma zonās laikā no 1963. līdz 2014. gadam.

\begin{tabular}{|c|c|c|c|}
\hline Dzilumu zona & Periods & $1963-1993$ & $1994-2014$ \\
\hline VISS & Novērojumi & 846 & 502 \\
\hline VISS & Determinācijas koeficients $\left(\mathrm{R}^{2}\right)$ & 0.2003 & 0.0855 \\
\hline VISS & Korelācijas koeficients (R) & -0.448 & +0.292 \\
\hline Dzilị̄īens zona (25 -50 m) & Novērojumi & 443 & 201 \\
\hline Dziḷūdens zona (25 -50 m) & Determinācijas koeficients $\left(\mathrm{R}^{2}\right)$ & 0.1551 & 0.0855 \\
\hline Dziḷūdens zona $(25-50 \mathrm{~m})$ & Korelācijas koeficients (R) & -0.394 & +0.292 \\
\hline Piekrastes zona $(0-25 \mathrm{~m})$ & Novērojumi & 403 & 301 \\
\hline Piekrastes zona $(0-25 \mathrm{~m})$ & Determinācijas koeficients $\left(\mathrm{R}^{2}\right)$ & 0.2529 & 0.0792 \\
\hline Piekrastes zona $(0-25 \mathrm{~m})$ & Korelācijas koeficients (R) & -0.503 & +0.281 \\
\hline
\end{tabular}

\section{Secinājumi}

1) apskatāmajā periodā kopumā ir vērojama būtiska ūdens caurspīdības samazināšanās,

2) ūdens caurspīdības un krāsas sezonālās izmaiņas praktiski nav vērojamas, 
3) konstatēti divi periodi ar atšķirīgām ūdens caurspīdības izmaiņu tendencēm, un proti, laikā no 1963.

- 1993. gadam vērojama samērā strauja ūdens caurspīdības samazināšanās, bet laikā no 1994 - 2014 gadam vērojama samērā lēna ūdens caurspīdības palielināšanās,

4) augšminētais artefakts varētu būt izskaidrojams ar saimniekošanas veida izmaiņu ietekmi uz vides stāvokli aptuveni pēc 1991. gada, ko daḷēji apstiprina straujā ūdens caurspīdības samazināšanās piekrastes zonā periodā no 1963. - 1993. gadam.

\section{Izmantotā literatūra:}

Захарченко Н.Е. Прозрачность вод Рижского залива, Сборник работ РГМО. - Рига, 1962. - Вып. 1. - c. 83 - 102 .

Berzinsh V. Hydrology. Ecosystem of the Gulf of Riga between 1920 and 1990. Edited by Prof. E. Ojaveer., Estonian Academy Publishers, Tallinn. 1995., p. 7 - 31. 


\title{
CEḶOTĀJZIVJU POPULĀCIJU STĀVOKLIS UN TĀ UZLABOŠANAS IESPĒJAS JUGLAS BASEINA UPĒS
}

\author{
Jānis BIRZAKS ${ }^{1}$, Kaspars ABERSONS ${ }^{1 *}$, Māris STRŪG̣IS ${ }^{1}$, Jānis BAJINSKIS ${ }^{1}$ \\ ${ }^{l}$ ZI „,BIOR” Zivju resursu pētniecības departaments \\ *e-pasts: kaspars.abersons@bior.gov.lv
}

Daugavas hidroelektrostaciju kaskādes izveidošanas rezultātā lielākā daḷa Daugavas baseina upju ceḷotājzivju nārsta migrācijai nav pieejama. Kopš 1974. gada, kad tika pabeigta Rīgas HES izbūve, ceḷotājzivīm pieejami nārstam un mazuḷu attīstībai piemēroti biotopi Daugavas baseinā ir saglabājušies tikai atsevišķās ūdenstecēs lejpus Rīgas HES. Pašlaik laša Salmo salar un taimiņa S. trutta Daugavas populācija tiek uzturēta mākslīgā ceḷā. Lai kompensētu Daugavas HES kaskādes izveidošanas negatīvo ietekmi, Daugavas baseinā tiek veikta arī upes nēǵa Lampetra fluviatilis mākslīgā pavairošana. Ceḷotājzivju mākslīga pavairošana ir saistìta ar papildu izdevumiem, to populācijās iespējamas arī negatīvas sekas (hominga zaudēšana, populācijas dzimuma, vecuma un geenētiskās struktūras izmainas u. c.). Mākslīgās pavairošanas negatīvie blakusefekti liek meklēt iespējas palielināt Daugavas baseina ūdensteču nozīmi ceḷotājzivju dabiskās atražošanās nodrošināšanā. Potenciāli nozīmīgākā no tām Daugavas lejtecē ir Juglas baseins. Tajā ietilpst Lielā Jugla, Mazā Jugla, kā arī vairākas nelielas ūdensteces. Juglas baseins līdz Dobelnieku un Ropažu HES aizsprostiem ir arī brīvi pieejams ceḷotājzivju migrācijai. Pētījuma mērḳis ir novērtēt ceḷotājzivju nārsta un mazuḷu attīstības potenciālu Juglas baseinā un identificêt pasākumus šĩ potenciāla palielināšanai. Mērḳa sasniegšanai Lielajā Juglā un Mazajā Juglā veikta upju straujteču, kas ir nēǵu nārsta vieta, kā arī laša un taimiṇa nārsta un mazuḷu attīstības biotops, kartēšana, ceḷotājzivju migrācijas šḳērṣ̌lu identificēšana, kā arī ihtiofaunas izpēte. Pētījums īstenots ar Rīgas brīvostas pārvaldes finansiālu atbalstu.

Pētijjuma lauka darbi veikti 2014. gada jūlijā. Straujteču kartěšana un ceḷotājzivju migrācijas šķērṣ̌̆lu apzināšana veikta, apsekojot upi ar laivu. Lielajā Juglā apsekots aptuveni $60 \mathrm{~km}$ garš posms lejpus Sidgundas, savukārt Mazajā Juglā - aptuveni $100 \mathrm{~km}$ gar $\square$ posms lejpus Vatrānes. Izmantojot Mobile mapper iekārtu, identificētas šķēšșlu un straujteču robežu atrašanās vietas LKS-92 koordinātu sistēmā. Lauka apstākḷos uzkrātajiem datiem pēcapstrādes procesā veikta diferenciāla korekcija, kas nodrošina mērijjumu un aprēkininu submetra precizitāti. Ihtiofaunas izpēte veikta saskaņā ar standartu LVS EN 14011:2003 Ūdens kvalitāte - Zivju paraugu ievākšana, lietojot elektrozveju. Zivju uzskaites 
parauglaukumos ar WTW Multi 340i analyzer zondi veikti skābekḷa koncentrācijas, pH līmeṇa, elektrovadītspējas un ūdens temperatūras mērījumi. Papildus elektrozvejai veikta arī nēǵu kāpuru uzskaite, izmantojot Latvijā izstrādātu metodi (grunts paraugu rakšana ar speciālu 0,2 m platu liekšķeri). Zivju uzskaite ar elektrozveju veikta upju straujtecēs, visā upes platumā. Lielajā Juglā elektrozveja veikta septiņos parauglaukumos posmā no Sidgundas līdz Zaķumuižai, savukārt Mazajā Juglā - deviņos parauglaukumos posmā no Kastrānes līdz Upeslejām. Nēǵu uzskaite veikta piecos parauglaukumos Lielajā Juglā (grunts paraugu kopējā platība 2,8 $\mathrm{m}^{2}$ ) un septiņos parauglaukumos Mazajā Juglā (grunts paraugu kopējā platība 4,76 m²). Elektrozvejas un nēǵu uzskaišu parauglaukumu izvietojums apskatāms 1. un 2. attēlā.

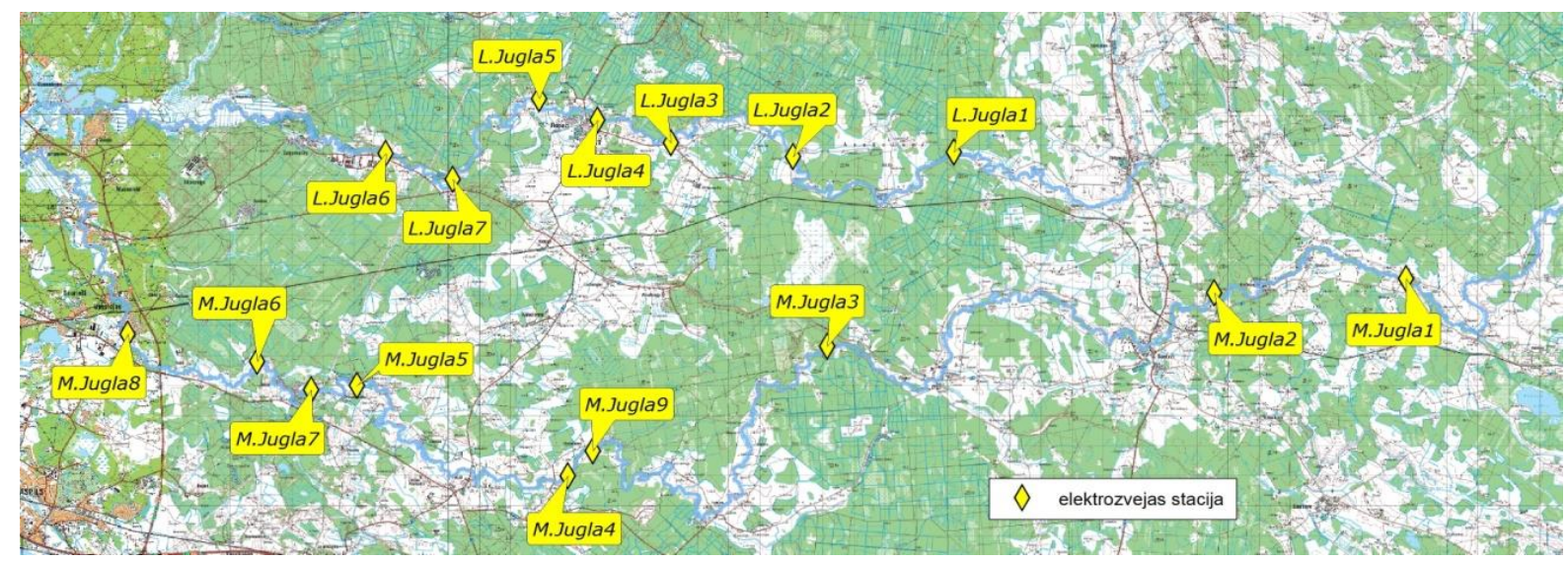

1. attēls. Elektrozvejas parauglaukumu izvietojums.

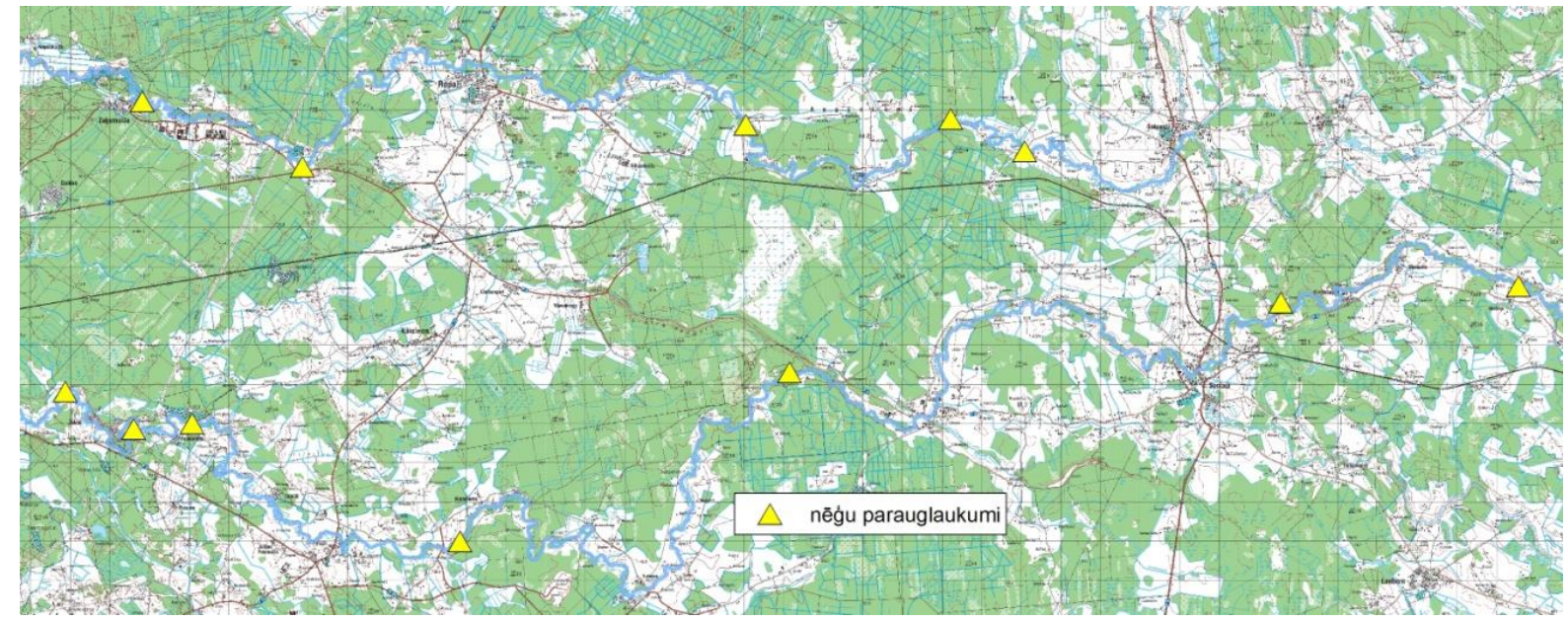

2. attēls. Nēǵu kāpuru uzskaites parauglaukumu izvietojums. 
Uzskaites laikā noḳertās zivis uzglabātas rezervuārā ar ūdeni. Pēc uzskaites beigām katrā parauglaukumā noķertie laša un taimiņa mazuḷi, kāa ari lielāka izmēra $(\mathrm{L}<10 \mathrm{~cm})$ citu sugu zivis nomērītas un atlaistas ūden̄i. Pārējās zivis fiksētas formalīnā un nogādātas laboratorijāa, kur noteikta to suga, garums (mm) un svars (g). Zivju sugas noteiktas saskaṇā ar jaunāko Eiropā pieņemto nomenklatūru (Kottelat, Freyhof, 2007). Nēǵu kāpuru uzskaite veikta tiem piemērotos biotopos. Visi noḳertie nēǵu kāpuri fiksēti formalīnā un nogādāti laboratorijā, kur noteikts to garums (mm) un svars (mg). Katrā grunts paraugā noḳertie nēǵu kāpuri fiksēti atsevišḳāa traukā. Balstoties uz iegūto kāpuru garuma un svara izkliedi un literatūras (Abakumov, 1957) datiem par nēǵu kāpuru augšanas ātrumu Latvijas upēs, kāpuri iedalīti vecuma grupās. Pašlaik nav izstrādāta droša un viegli lietojama metode upes nēğa un strauta nēǵa Lampetra fluviatilis kāpuru sugu noteikšanai (Gardiner, 2003). Š̃̄ pētîjuma ietvaros tika pieņemts, ka Lielajā Juglā un Mazajā Juglā sastopamas abas nēǵu sugas.

Apsekotajā Lielās Juglas posmā tika identificētas 43 straujteces ar kopējo platību 70,9 ha, savukārt apsekotajā Mazās Juglas posmā - 101 straujtece ar kopējo platību 94,8 ha. Būtiska straujteču aizaugšana vai degradācija, kas neatbilst ceḷotājzivju ekoloǵiskajām prasībām, netika konstatēta. Dažāda vecuma laša un taimiņa mazuḷiem ir atšķirīgas prasības pret dzīves vidi (Jonsson, Jonsson, 2011). Minētā iemesla dēl, par lasim un taimiņam potenciāli piemērotākiem var uzskatīt platības ziṇā lielākos un daudzveidīgākos straujteču - krāču kompleksus. Lielajā Juglā šādas straujteces atrodas ap Ropažiem, kā arī pie Ķezberu un Upessužu mājām, to kopējā platība ir 41 ha. Mazajā Juglā tādas straujteces atrodas augšpus Ķieǵeḷcepḷa, pie Kranciema, augšpus Turkalnes un pie Dobelniekiem, to kopējā platīiba ir 38 ha (3. attēls).

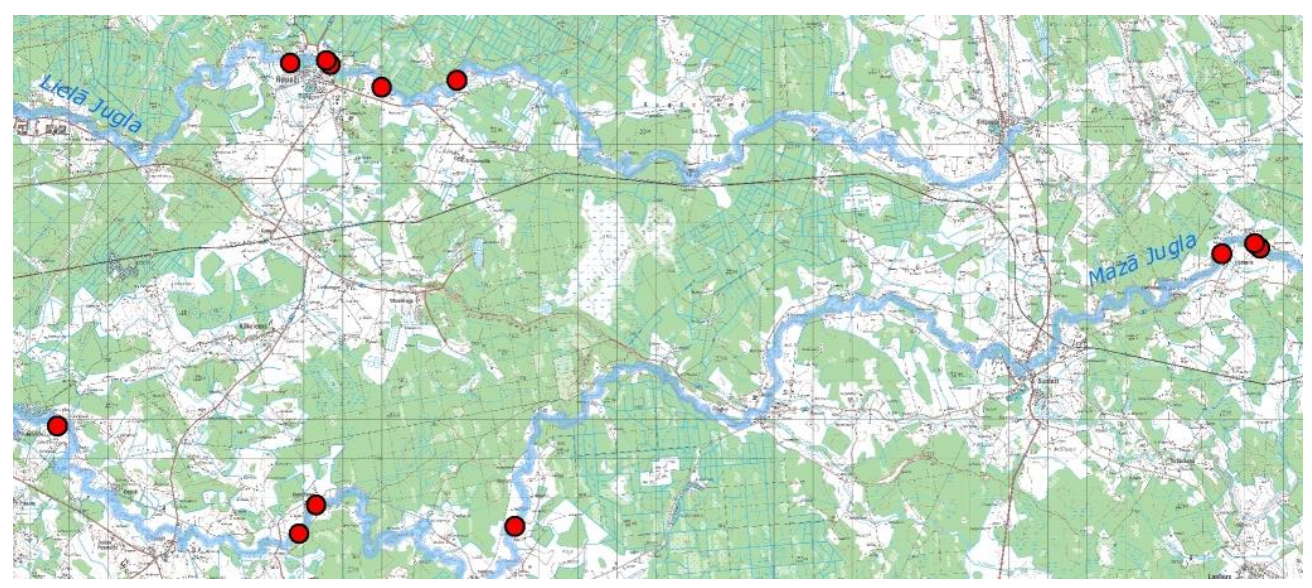

3. attēls. Lasim un taimiņam potenciāli piemērotāko straujteču - krāču kompleksu atrašanās vietas Lielajā Juglā un Mazajā Juglā. 
Ceḷotājzivju izplatību būtiski ietekmē antropogēnie šķērṣ̌li. Mazajā Juglā pirmais no tiem ir aptuveni 30 km no grīvas esošais Dobelnieku HES, bet Lielajā Juglā - aptuveni 36 km no grīvas esošais Ropažu HES aizsprosts. Gan Lielajā Juglā, gan Mazajā Juglā zivju migrāciju ierobežo arī citi šḳēršli - sabrukušu aizsprostu paliekas, mākslīgi veidoti akmeṇu krāvumi, koku sanesumi u. c. Vairākās Lielās Juglas un Mazās Juglas pietekās ceḷotājzivju migrāciju ierobežo arī caurtekas zem ceḷiem un bebru aizsprosti. Dažādu šḳēršlu potenciālā ietekme uz zivju migrāciju šì pētījuma ietvaros netika vērtēta.

Pavisam kopā Lielajā Juglā tika konstatētas 18 zivju sugas un nēǵu kāpuri, savukārt Mazajā Juglā 22 zivju sugas un nēğu kāpuri. Mazajā Juglā konstatēta arī jauna ziemeḷu zeltainā akmeņgrauža Sabanejewia baltica atradne Latvijā. No uzskaitē konstatētajām sugām trīs ir anadromās (lasis, taimiņš un upes nēǵis) un viena katadromā (zutis) ceḷotājzivs. Lielākajā daḷā parauglaukumu abās ūdenstecēs konstatētas arī vairākas zivju sugas (platgalve Cottus gobio, bārdainais akmeņgrauzis Barbatula barbatula, mailīte Phoxinus phoxinus u. c.), kas Latvijā nereti sastopamas kopā ar taimiṇu / strauta foreli (Birzaks, 2012). Mērītie ūdens raksturlielumi zivju uzskaites parauglaukumos kopumā atbilda ceḷotājzivju prasībām. Šie fakti ḷauj secināt, ka gan Lielās Juglas, gan Mazās Juglas straujteces kopumā ir piemērotas anadromajām lašveidīgajām zivīm.

Laša mazuḷi konstatēti tikai vienā parauglaukumā Lielajā Juglā un vienā parauglaukumā Mazajā Juglā. Retā sastopamība un fakts, ka konstatētas tikai vienas (1+) vecuma grupas zivis, ḷauj pieṇemt, ka konstatētie laša mazuḷi ir audzētavu izcelsmes. Taimiṇi / strauta foreles Lielajā Juglā konstatētas četros, bet Mazajā Juglā - piecos parauglaukumos. Salīdzinoši plašā izplatība un vismaz divu $(0+$ un $1+)$ vecuma grupu mazuḷu konstatēšana ļauj pieņemt, ka Lielajā un Mazajā Juglā norisinās taimiņa / strauta foreles dabiskā atražošanās. Taimiņu nārsta iespējamību Mazajā Juglā apliecina arī viena pieauguša taimiņa īpatṇa konstatē̌̌ana Mazajā Juglā. Jāpiezīmē, ka šis īpatnis tika noḳerts augšpus Dobelnieku HES aizsprosta, kas liecina, ka labvēlīgos apstākḷos migrējošās zivis šo aizsprostu spēj pārvarēt. Laša un taimiņa mazuḷu īpatņu blīvums bija neliels un nepārsniedza 1 eks./100 m². Iespējamos nelielā populācijas blīvuma iemeslus pašlaik precīzi identificēt nav iespējams. Kā ticamāko var izvirzīt hipotēzi, ka šo sugu vaislinieku skaits ir nepietiekams biotopu platībai. Potenciāli nozīmīgākie iemesli tam varētu būt mazs īpatṇu skaits populācijās, plēsēju ietekme uz mazuḷu un smoltu produkciju, smoltu 
mirstība lejupmigrācijas laikā, kāa arī antropogēno šķēršḷu un zvejas (arī nelegālās) ietekme uz pieaugušo īpatņu augšupmigrāciju.

Nēǵu kāpuri tika konstatēti visos uzskaites parauglaukumos, izṇemot vienu parauglaukumu tiešāa Ropažu HES tuvumā. Gan Lielajā Juglā, gan Mazajā Juglā nēǵu kāpuru īpatṇu blīvumam ir tendence palielināties virzienā no augšteces uz lejteci. Vidējais nēğu kāpuru īpatṇu blīvums lejpus HES ietekmes zonas bija 20,0 eks./m² Lielajā Juglā un 27,8 eks./m² Mazajā Juglā, savukārt vidējais īpatṇu blīvums augšpus HES ietekmes zonas bija 4,9 eks./m² Lielajā Juglā un 11,4 eks./m² Mazajā Juglā. Šie rādītāji kopumā atbilst situācijai citās Latvijas upēs augšpus un lejpus upes nēǵa migrācijas šḳēršḷiem (Abersons, nepublicēti dati). Domājams, ka mazāks nēğu kāpuru īpatṇu blīvums augšpus HES aizsprostiem skaidrojams ar to, ka šajos upju posmos nārsto galvenokārt strauta nēgí, kuru potenciālā auglība nelielā izmēra un ikru skaita dēḷ ir daudzkārt mazāka nekā upes nēǵiem. Normāla kāpuru vecuma struktūra konstatēta tikai Mazajā Juglā. Iespējams, ka Lielajā Juglā upes nēǵu nārsts nenorisinās katru gadu.

Zuši Lielajā Juglā un Mazajā Juglā konstatēti tuvāk lejtecei esošajos parauglaukumos (Lielajā Juglā parauglaukumos Nr. 3, 4, 5, 6, un 7, savukārt Mazajā Juglā parauglaukumos Nr. 5, 7, un 9). To izmērs l̦auj secināt, ka tas ir 2011. un 2014. gadā Juglas ezerā un ar to savienotajos ezeros un upēs veiktās stikla zušu ielaišanas rezultāts. Jāpiezīmē, ka atsevišḳi zušu īpatṇi bija spējuši pārvarēt Dobelnieku HES un Ropažu HES aizsprostus.

Rezultāti liecina, ka Lielā Jugla un Mazā Jugla kopumā ir piemērotas gan anadromajām, gan katadromajām ceḷotājzivīm. To nelielo skaitu un relatīvi mazo populāciju blīvumu, visticamāk, nosaka nepietiekams vaislinieku skaits. Par ceḷotājzivju populāciju stāvokḷa uzlabošanai prioritāriem uzskatāmi pasākumi to īpatņu skaita un izplatības palielināšanai. Lašu un taimiņu mazuļu ielaišanu vēlams veikt pēc platības lielākajos straujteču posmos. Nēǵu kāpuru ielaišanai potenciāli nozīmīgāki ir upju posmi augšpus HES aizsprostiem. Kāpuru ielaišanu var aizstāt arī ar nēǵa vaislinieku pārvešanu pāri Ropažu HES un Dobelnieku HES aizsprostam. Lai novērtētu pasākumu efektivitāti, 2015. un 2016. gadā plānots veikt mazuḷu un kāpuru uzskaiti Lielajā Juglā un Mazajā Juglā. 


\section{Izmantotā literatūra:}

Abakumov, V., A. 1957. К биологической характеристике проходной миноги рек Латвийской и Эстонской ССР. [Par migrējošo nēǵu biologisko raksturojumu Latvijas un Igaunijas PSR upēs]. Trudy Mosrybtuza. No. 8: 278-283. (Krievu valodā).

Birzaks, J., 2012. Occurrence, abundance and biomass of fish in rivers of Latvia in accordance with river typology. Zoology and Ecology, 22: 1, 9-19.

Gardiner, R., 2003. Identifying Lamprey. A Field Key for Sea, River and Brook Lamprey. Conserving Natura 2000 Rivers. Conservation Techniques Series No. 4. English Nature, Peterbourgh.

Jonsson, B., Jonsson, N. 2011. Ecology of Atlantic salmon and brown trout: habitat as a template for life histories. Dordrecht: Springer-Verlag.

Kottelat, M., Freyhof, J. 2007. Handbook of European Freshwater Fishes. Berlin. 


\title{
BALTIJAS JŪRAS PIEKRASTES ZIVJU SABIEDRĪBAS IZMAIṆAS PĒDĒJO GADU LAIKĀ
}

\author{
Laura BRIEKMANE ${ }^{1 *}$, Didzis USTUPS ${ }^{1}$, Elīna KNOSPIN̦A ${ }^{1}, \bar{E}^{2}$ alds URTĀNS ${ }^{2}$ \\ ${ }^{1}$ Pārtikas drošības, dzīvnieku veselības un vides zinātniskais institūts “BIOR”, Daugavgrīvas iela 8, Rīga \\ ${ }^{2}$ Latvijas Zvejnieku federācija \\ *e-pasts: laura.briekmane@bior.gov.lv
}

Pēc Latvijas Republikas normatīvajiem aktiem par piekrastes zonu sauc Baltijas jūras un Rīgas jūras līča ūdeṇu daḷu, kuras dziḷ̂ums nepārsniedz 20 metrus (Ministru kabineta noteikumi Nr. 296, 2007). Baltijas jūras piekrastes zonai ir nozīmīga loma daudzu dzīvo būtņu, t.sk zivju un putnu, ekoloǵijā; piekrastes ūdeṇi kalpo kā nozīmīgas nārsta un barošanās vietas gan zivju mazuliiem, gan pieaugušām zivīm (Ustups et al., 2003). Baltijas jūras piekrastes zivju sabiedrības tiek pārstāvētas gan ar saldūdens, gan jūras, gan diadromo jeb ceḷotājzivju sugām (Ojaver, Pihu, 2003), un zivju sabiedrības sastāvu būtiski ietekmē dažādi hidrodinamiskie faktori - vēja stiprums un virziens, viḷınu augstums, gaisa un ūdens temperatūras izmaiņas, apvelinga process u.c. (Beyst et al., 2001). Pētîjuma rajons Liepājas piekraste - ir unikāla vieta Baltijas jūras atklātajā dạ̣ā, kur novērojama viena no lielākajām biolog̣iskajām daudzveidībām piekrastes zonā. To nosaka gan saldūdens ietekme no Liepājas ezera un Kuršu līča, gan atklātās jūras ietekme.

Latvijā dati par zivju sabiedrībām piekrastē tiek iegūti galvenokārt realizējot Latvijas Nacionālo zivsaimniecības datu vākšanas programmu, veicot kontrolzvejas uzskaites vienu vai vairākas reizes mēnesī noteiktās vietās Baltijas jūras atklātās daḷas un Rīgas jūras līča piekrastē. Šì pētījuma ietvaros tika analizēta zivju sabiedrība Liepājas piekrastē laika posmā no 2005. - 2014. gadam (ieskaitot). Paraugošana veikta no mēnešos no maija līdz septembrim (ieskaitot), kas vēlākai datu analīzei iedalīti divās sezonās: pavasaris (maijs, jūnijs) un vasara (jūlijs, augusts, septembris). Materiāls tika ievākts izmantojot zinātniskās uzskaites vîtā neilona linuma tīklus ar acs izmēru starp mezgliem 17, 22, 25, 30, 33, 38, 50 un $60 \mathrm{~mm}$; tīklu augstumu - 1,8 metri. Zveja veikta piekrastes zonā dzilumā no 5-6 metriem. Tīklu ekspozīcijas laiks - viena nakts. Visām tīklos noḳertajām zivīm tika noteikta suga, garums un svars. Atsevišķām zivju sugām dažos gados noteikts arī dzimums un dzimumnobriešanas stadija, kā arī veiktas piezīmes par slimībām u.c. svarīga informācija. Tā kā zvejas aktu skaits pa gadiem variēja, lai standartizētu iegūtos datus, tika aprēḳināta nozveja uz piepūles vien̄̄bu. Piekrastes zivju sabiedrības 
daudzveidības noteikšanai aprēḳinātas Šenona indeksa vērtības pa gadiem un sezonām. Statistiskās analīzes tika veiktas programmā $R$ pie būtiskuma līmeņa $p=0,05$ (R Core Team, 2013).

Kopumā no 2005. - 2014. gadam Liepājas piekrastē analizēti 79 zvejas akti (37 pavasara un 42 vasaras sezonā). Pa visiem gadiem kopumā noķertas 34 zivju sugas (1. tabula). Vislielākais sugu skaits reǵistrēts 2010. gadā un 2013. gadā, kas visticamāk skaidrojams ar lielāko veikto zvejas aktu skaitu šajos gados (lielāka iespējamība noḳert t.s. "retās sugas").

1. tabula. Liepājas piekrastē noķerto zivju īpatsvars pa gadiem pēc to skaita no 2005.-2014. gadam

\begin{tabular}{|c|c|c|c|c|c|c|c|c|c|c|c|}
\hline Suga & Latīniskais nosaukums & 2005 & 2006 & 2007 & 2008 & 2009 & 2010 & 2011 & 2012 & 2013 & 2014 \\
\hline Apaḷais jūrasgrundulis & Neogobius melanostomus & & 0 & 0 & () & ) & (1) & (1) & $\boldsymbol{9}$ & - & - \\
\hline Plicis & Blicca bjoerkna & 0 & C & C) & ( & () & () & $\boldsymbol{\bullet}$ & () & () & ( \\
\hline Plekste & Platichtys flesus trachurus & ( & ( & $\bullet$ & ( & () & ( & ( & 0 & () & () \\
\hline Asaris & Perca fluviatilis & 0 & () & () & ( & () & () & - & 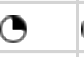 & () & 6 \\
\hline Reṇǵe & Clupea harengus membras & ( & (1) & 0 & ( & (1) & $\odot$ & 0 & 0 & () & $\odot$ \\
\hline Rauda & Rutilus rutilus & ( & ○ & 0 & ( & ( & ○ & ○ & () & () & 0 \\
\hline Vimba & Vimba vimba & (1) & C & ( & 0 & 0 & 0 & 0 & () & 0 & 0 \\
\hline Salaka & Osmerus eperlanus & $\boldsymbol{\bullet}$ & 0 & 0 & 0 & 0 & 0 & 0 & 0 & 0 & 0 \\
\hline Akmenplekste & Psetta maxima & 0 & 0 & 0 & 0 & 0 & 0 & 0 & 0 & 0 & 0 \\
\hline Zandarts & Stizostedion lucioperca & 0 & 0 & 0 & 0 & 0 & 0 & 0 & 0 & 0 & 0 \\
\hline Plaudis & Abramis brama & & & & & & 0 & 0 & 0 & 0 & 0 \\
\hline Menca & Gadus morhua callarias & 0 & 0 & 0 & 0 & & 0 & 0 & 0 & 0 & 0 \\
\hline Ziemeḷu jūrasbullis & Myoxocephalus scorpius scorpius & & 0 & & 0 & 0 & 0 & 0 & & & 0 \\
\hline Brētliṇa & Sprattus sprattus balticus & 0 & & 0 & & 0 & 0 & 0 & 0 & 0 & 0 \\
\hline Vējzivs & Belone belone & & & 0 & 0 & 0 & 0 & & & 0 & \\
\hline Palede (lapreṇge) & Alosa fallax & 0 & 0 & 0 & 0 & & & 0 & 0 & 0 & 0 \\
\hline Taimiṇš & Salmo trutta & 0 & & 0 & 0 & 0 & 0 & 0 & & 0 & \\
\hline Vīke & Alburnus alburnus & 0 & 0 & & & & & 0 & 0 & 0 & 0 \\
\hline Sīga & Coregonus lavaretus & 0 & & & 0 & & 0 & & & & 0 \\
\hline Nigliṇš & Hyperoplus lanceolatus & & 0 & & 0 & 0 & 0 & 0 & & & 0 \\
\hline Ālants & Leuciscus idus & & 0 & & & & & 0 & 0 & & 0 \\
\hline Lìdaka & Esox lucius & 0 & & & 0 & & & & & 0 & \\
\hline Tūbīte & Ammodytes tobianus & 0 & & & & & & & 0 & 0 & 0 \\
\hline Salate & Aspius aspius & & & & 0 & 0 & & & & & 0 \\
\hline Lucītis & Zoarces viviparus & & 0 & & & & & & & & \\
\hline Kīisis & Gymnocephalus cernua & & & & & 0 & & & & 0 & \\
\hline Jūras stagars & Spinachia spinachia & & & & 0 & & & & & & \\
\hline Trīsadatu stagars & Gasterosteus aculeatus & & & & 0 & & & & & & \\
\hline Jūras dzelongalve & Taurulus bubalis & & & & & & 0 & & & 0 & \\
\hline Zeltplekste & Pleuronectes platessa & & & & & & 0 & & & & \\
\hline Atlantijas store & Acipenser sturio & & & & & & & & & 0 & \\
\hline Čūskzivs & Nerophis ophidion & & & & & & & 0 & & & $\angle \ddot{4}$ \\
\hline Sudrabkarūsa & Carassius auratus & & & & & & 0 & & & & \\
\hline Zutis & Anguilla anguilla & & & & & & 0 & & & & \\
\hline Kopā & & 17 & 17. & 15 & 21 & 17 & 22 & 20 & 17 & 22 & 21 \\
\hline Apzīmējumi: $\bigcirc<5 \%$ & $(-<15 \%$ & $<45 \%$ & & & $100 \%$ & & & & & & \\
\hline
\end{tabular}


Analizējot zivju sugu procentuālo sadalījumu pēc skaita pa gadiem, secināms, ka vairumā gadu zivju sabiedrību veido daudzas sugas, bet to īpatsvars procentos no kopējā zivju

skaita ir neliels. Izṇēmums ir atsevišķas sugas - asaris, plekste, plicis, rauda, reṇǵe - kas vairākumā gadu ihtiocenozē ir sastopamas no 5 līdz pat 45\% no kopējā noķerto zivju skaita. Tas pats ir attiecināms arī uz invazīvo zivju sugu - apaḷo jūrasgrunduli, kas Liepājas piekrastes zivju sabiedrībā parādījās 2006. gadā, bet, noḳerto šīs sugas īpatņu skaitam ik gadu strauji pieaugot, pēdējos divos gados tas veido vairāk kā 45\% no kopējā noķerto zivju skaita. Jāatzīmē, ka 1. tabulā dotā informācija atspoguḷo zivju skaita kopējo īpatsvaru gan pavasara, gan vasaras sezonās. Analizējot zivju skaita īpatsvaru pa sezonām, secināms, ka apaḷā jūrasgrunduḷa dominance zivju sabiedrībā gan skaita, gan biomasas ziņā vērojama tikai pavasara sezonā, kas saistīts ar to aktivitātes pieaugumu un migrācijām uz piekrasti pirmsnārsta laikā. Vasaras sezonā apaḷais jūrasgrundulis veido tikai 7\% no kopējā zivju skaita un 5\% no kopējās zivju biomasas. Iepriekšējie pētījumi liecina, ka vasarā, apaḷā jūrasgrunduḷa nārsta laikā, š̄̄s zivis ir izteikti mazkustīgas, kā rezultātā, veicot uzskaiti ar pasīviem zvejas rīkiem, to skaits tiek novērtēts par zemu (Johnson et al., 2005).

Analizējot zivis pēc to piederības ekoloǵiskajām grupām (1. attēls) ir secināms, ka Liepājas piekrastes zivju sabiedrībā ir sastopamas gan jūras, gan saldūdens, gan ceḷotājzivju (anadromās un katadromās) zivju sugas, līdzīgi kā tas ir citviet Baltijas jūras piekrastē (Ojaver, Pihu, 2003).

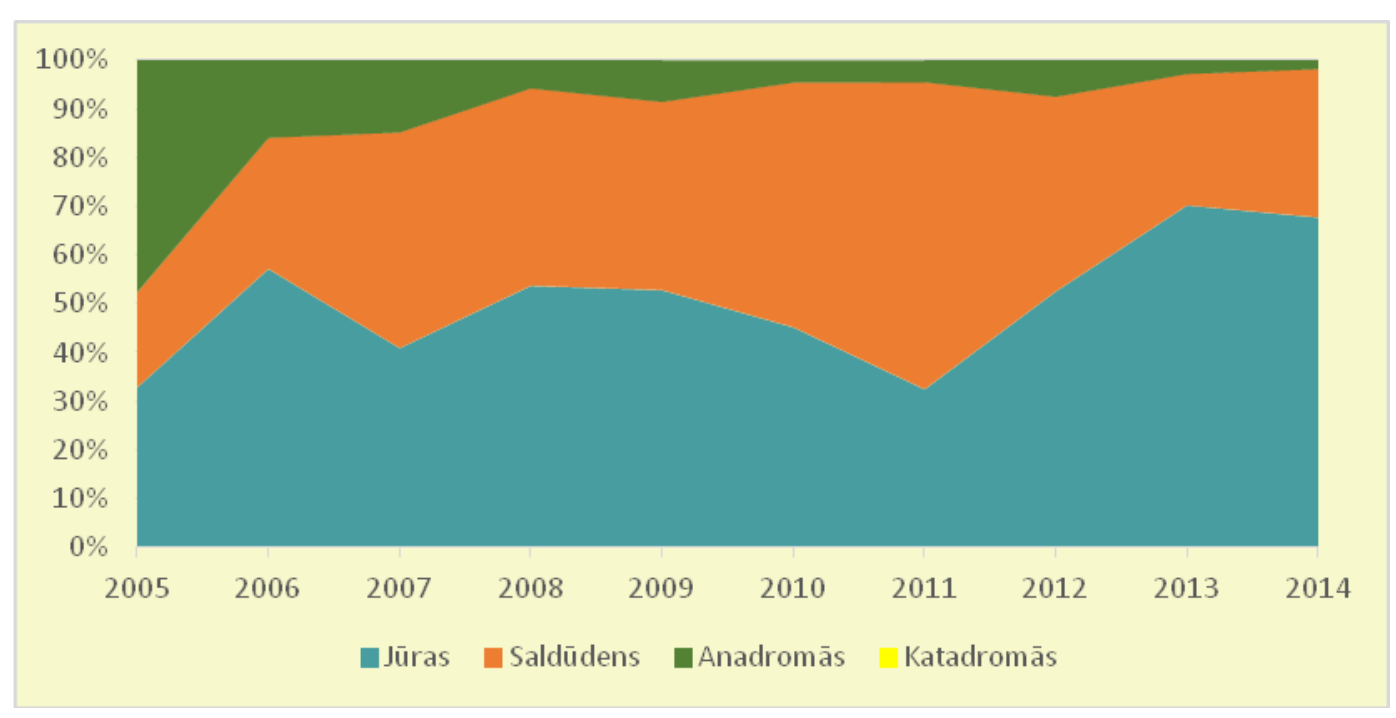


1. attēls. Zivju sadalījums ekologiiskajās grupās pēc kopējā noķerto zivju skaita no 2005. - 2014. gadam.

No katadromajām sugām Liepājas piekrastē ir sastopama tikai viena suga - zutis, kas Liepājā tīklos tika noḳerta tikai 2010. gadā, līdz ar to kopējā zivju ekoloğisko grupu sadalījumā katadromo zivju īpatsvars ir niecīgs. Tas saistīts arī ar šīs zivs ekoloǵiju - tās uzskaitei tiek izmantoti citi zvejas rīki (āķi).

1. attēlā redzams, ka pārējo zivju ekolog̣isko grupu sadalījums pa gadiem mainās. Galvenās izmaiņas saistītas ar jūras un saldūdens zivju īpatsvara izmaiņām pa gadiem, ko, iespējams, varētu skaidrot ar ūdens temperatūras izmaiņām. Saldūdens zivju īpatsvara palielināšanās piekrastē notiek siltūdens periodā, t.i. galvenokārt vasaras sezonā, ja vien ilgstošu krasta vēju ietekmē nav novērojams apvelinga process, kad siltais ūdens slānis tiek iepūsts dziḷāk jūrā, tādējādi virspusē nonākot aukstajam ūdenim un līdz ar to zivju sabiedrībā dominē jūras zivis (Miller, Wheeler, 2012). Tomēr, lai pārbaudītu zivju ekolog̣isko grupu īpatsvara izmaiņu saistību ar ūdens temperatūru, vēja virzienu un stiprumu, būtu jāveic iegūto datu analīze kopā ar attiecīgo hidrodinamisko faktoru kopumu.

Lai analizētu vai un kā ir mainījusies zivju sugu daudzveidība Liepājas piekrastē desmit gadu laikā, tika aprēḳināts Šenona daudzveidības indekss visos gados atkarībā no sezonas (2. attēls). Indeksa vērtības pavasara sezonā pa gadiem variēja no 0,74 līdz 1,90, savukārt vasaras sezonā - no 1,21 līdz 1,99. Attēlā redzams, ka gandrīz visos gados novērojama sakarība - Šenona indeksa vērtības pavasara sezonā ir apgriezti proporcionālas vērtībām vasaras sezonā attiecīgajā gadā.

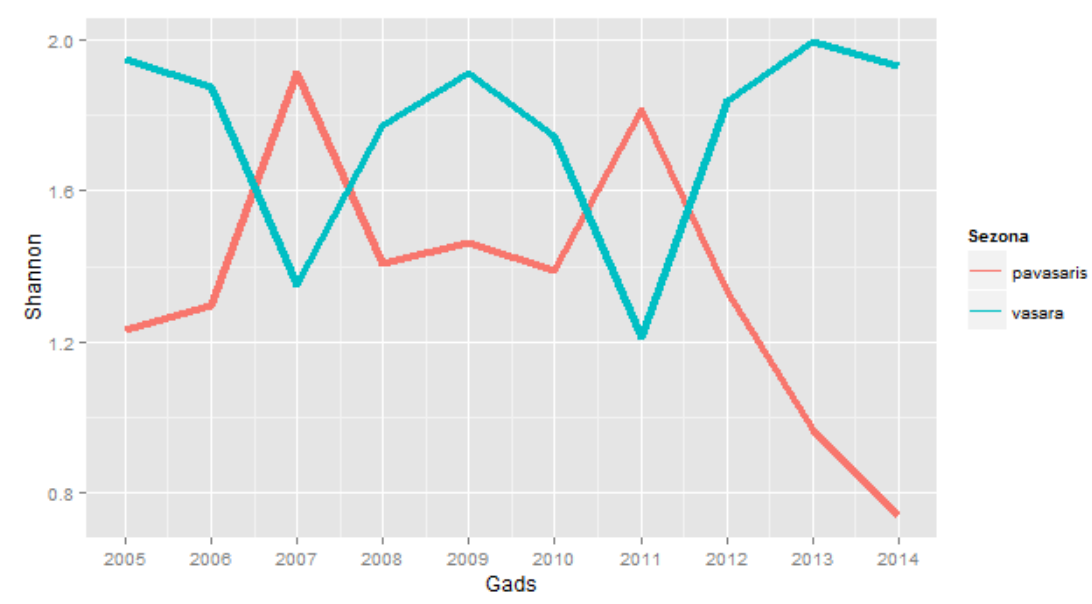


2.attēls. Šenona daudzveid̄̄bas indekss zivju sabiedrībai Liepājas piekrastē no 2005. - 2014. gadam pavasara un vasaras sezonās.

Tāpat novērojama sakarība starp Šenona indeksa vērtībām vasaras sezonā un zivju ekologisko grupu sadalījumu (1. attēls). 2007. un 2010. gadā bija novērojams lielāks saldūdens zivju īpatsvars zivju sabiedrībā, kas, kā minēts iepriekš, varētu būt saistīts ar augstu ūdens temperatūru vasaras sezonā un sekojoši - ar saldūdens zivju migrāciju no upēm uz piekrasti. Savukārt apvelinga laikā saldūdens zivju īpatsvars ihtiocenozē ir mazāks, savukārt kopējā zivju daudzveidība palielinās (Miller, Wheeler, 2012).

2. attēlā redzams, ka kopš 2011. gada pavasara sezonā zivju daudzveidība strauji samazinās. N̦emot vērā jau iepriekš pieminēto apaḷā jūrasgrunduḷa straujo pieaugumu pēdējos gados pavasara sezonā, kā arī augsto īpatsvaru zivju sabiedrībā gan pēc skaita, gan biomasas šajā sezonā, tika veikta regresijas analīze, lai noskaidrotu, vai apaḷā jūrasgrunduḷa skaita pieaugums izskaidro Šenona indeksa samazinājumu pavasara sezonā. Iegūtais grafiks (3. attēls) parāda, ka šāda sakarība laika periodā no 2006. gada, kad Liepājas piekrastes zivju uzskaitēs parādās apalais jūrasgrundulis, ir novērojama un ir statistiski būtiska $(p=0,018)$.

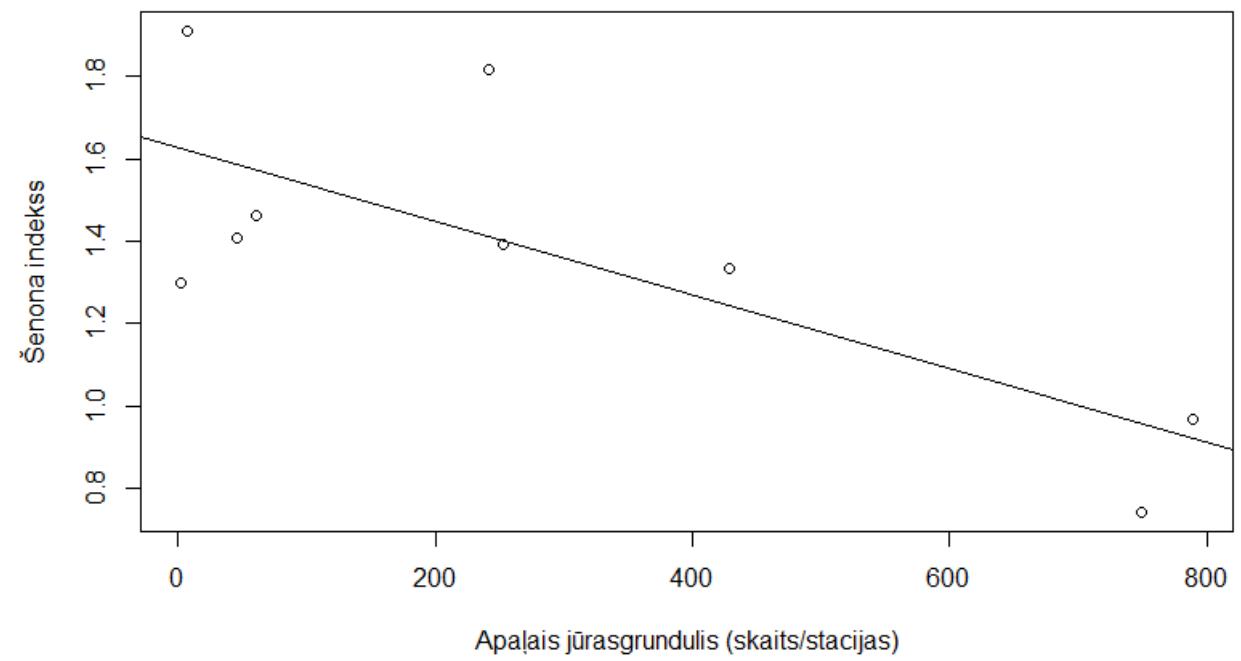

3. attēls. Šenona indeksa vērtības atkarība no apaḷā jūrasgrunduḷa skaita no 2006. - 2014. gadam. 
Apaḷā jūrasgrunduḷa skaits pavasara sezonā laika posmā no 2006. - 2014. gadam izskaidro 51\% no Šenona indeksa variēšanas $\left(\mathrm{R}^{2}=0,510\right)$. Savukārt noḳerto š̄is sugas īpatņu skaitam pa gadiem pieaugot, laika periodā no 2011. - 2014. gadam sugas lielais īpatsvars pavasara sezonā joprojām ir statistiski būtisks $(p=0,043)$, turklāt izskaidro jau 87\% no Šenona indeksa variēšanas pavasara sezonā $\left(\mathrm{R}^{2}=0,871\right)$.

Savukārt analizējot, vai apaḷā jūrasgrunduḷa skaita pieaugums pavasara sezonā ir ietekmējis vietējo sugu skaitu (4. attēls), redzams, ka invazīvā suga pēdējos gados aizṇem arvien lielāku īpatsvaru no kopējā noḳerto zivju skaita, kas izskaidro arī ietekmi uz Šenona indeksa vērtībām pavasara sezonā, tomēr pārējo zivju sugu skaita vērtību variēšana pa gadiem ar apaḷā jūrasgrunduḷa skaita pieaugumu tiešā veidā nav saistîta. Lai noskaidrotu, vai un kādā veidā apaļais jūrasgrundulis ietekmē atsevišḳas zivju sugas, būtu jāveic papildus pētījumi, iekḷaujot arī sugu savstarpējo attiecību, tai skaitā konkurences par barības objektiem u.c. resursiem, analīzi. Tāpat ietekmes noskaidrošanai būtu nepieciešams pētīt iespējamo konkurentu vidējā svara izmaiņas pa garuma grupām.

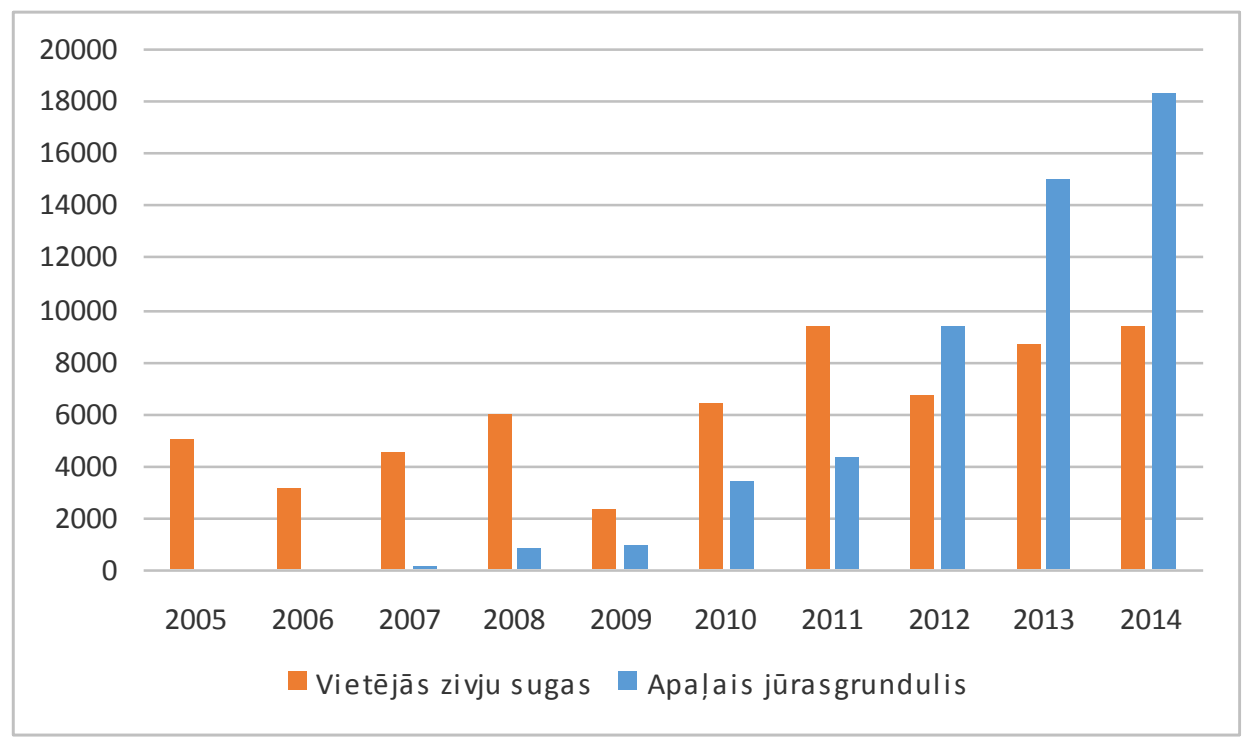

4. attēls. Apaḷā jūrasgrunduḷa un vietējo sugu skaita izmaiņas no 2005. - 2014. gadam pavasara sezonā.

Kopumā secināms, ka laika posmā no 2005. - 2014. gadam zivju sabiedrība Liepājas piekrastē ir mainījusies gan kopējā noķerto sugu skaitā pa gadiem, gan zivju ekoloǵisko grupu sadalījumā, gan arī 
sugu daudzveidības ziṇā. Būtiskas izmaiņas piekrastes zivju sabiedrībā ir notikušas saistībā ar invazīvās zivju sugas - apaḷā jūrasgrunduḷa - ekspansiju. Pēdējos gados tas ir kḷvis ne tikai par interesantu objektu zinātniekiem un makšķerniekiem, bet ieņem aizvien nozīmīgāku vietu piekrastes zvejnieku lomos. Kaimiņvalstu (Polijas, Lietuvas), kur šīs sugas invāzija notika agrāk, pieredze liecina, ka apaḷais jūrasgrundulis pēc straujas ekspansijas pirmajos gados ieņem būtisku lomu piekrastes zivju ekosistēmā (Sapota, 2004). Tomēr nākotnē būtu nepieciešams veikt padziḷinātu pētījumu par Liepājas piekrastes zivju sabiedrības izmaiṇām, iekḷaujot atsevišḳu sugu ekoloğijas un sugu savstarpējo attiecību, piemēram, konkurences par resursiem, analīzi.

Pêtîjums ir veikts ar Valsts pētījumu programmas "Latvijas ekosistēmu vērtība un tās dinamika klimata ietekmē, EVIDENT", projekta "Svešo sugu izplatība un ietekme uz Baltijas jūras un saldūdens ekosistēmām" atbalstu.

\section{Izmantotā literatūra:}

Beyst B., Hostens K., Mees J. 2001. Factors influencing fish and macrocrustacean communities in the surf zone of sandy beaches in Belgium: temporal variation. Journal of Sea Research, 46:281-294.

Johnson T., Allen M., Corkum L., Lee V. 2005. Comparison of methods needed to estimate population size of round gobies (Neogobius melanostomus) in western Lake Erie. Journal of Great Lakes Research, 31:7886.

Miller C., Wheeler P. 2012. Biological Oceanography: 2nd edition. Wiley-Blackwell, 504.

Ministru kabineta noteikumi Nr. 296 "Noteikumi par rūpniecisko zveju teritoriālajos ūdeņos un ekonomiskās zonas ūden,os". Pieņemti Rīgā, 2007. gada 2. maijā.

Ojaver E., Pihu E. 2003. Estonian natural fish waters. Fishes of Estonia, Estonian Academy Publishers, Tallinn, 15-27.

Sapota M. 2004. The round goby (Neogobius melanostomus) in the Gulf of Gdańsk - a species introduction in the Baltic Sea. Biology of the Baltic Sea Developments in Hydrobiology, 176:219-224.

Ustups D., Urtans E., Minde A., Uzars D. 2003. The structure and dynamics of fish communities in the Latvian coastal zone (Pape-Pērkone), Baltic Sea. Acta Universitaris Latviensis, 2003, 662:33-44.

R Core Team 2013. R: A language and environment for statistical computing. R Foundation for Statistical Computing, Vienna, Austria. URL: http://www.R-project.org/. 


\title{
RĪGAS PILSĒTAS ŪDENSTILPJU NOVĒRTĒJUMS,
}

\section{ANALIZĒJOT PROTOZOOPLANKTONA SABIEDRĪBU SEZONALITĀTI}

\author{
Linda BUHOLCE ${ }^{1 *}$, Elmīra BOIKOVA ${ }^{2}$, Vita LİCīTE², Uldis BOTVA ${ }^{2}$ \\ ${ }^{1}$ LU Biologijas fakultāte, Kronvalda bulvāris 4, Rīga \\ ${ }^{2}$ Biologijas Institüts, Miera iela 3, Salaspils \\ *e-pasts: lindabuholce@gmail.com
}

Protozooplanktona organismi - ciliāti ir galvenie pikoplanktona un nanoplanktona konsumenti, kuri veido būtisku pirmproducentu komponenti ezeros (Laybourn- Parry, 1992; Mathes, Arndt, 1995 cit. pēc Xu, Cronberg, 2010). Tādējādi tie spēlē nozīmīgu lomu enerğijas plūsmas kiēdē ūdens ekosistēmās (Fenchel, 1987; LaybournParry, 1992; Arndt, Berninger, 1995 cit. pēc Zou Q et al. 2013). Pateicoties augstajām vairošanās spējām ciliāti strauji reag̃ē uz vides izmaiñām, (Sládeček, 1973; Foissner, 1988; Berger et al., 1997 cit. pēc Pfister et al. 2002). Līdz ar to šie vienšūnas organismi tiek uzskatīiti par labu vides ekoloǵiskā stāvokḷa novērtētāju, jo atspoguḷo organiskā, eitrofā un citu antropogēno piesārn,ojumu skartās zonas.

Uzsākot urbānās vides hidroekosistēmu pētījumus ar mērki aprobēt pilsētasvides modelıkositēmu pielietojumu vides kvalitātes novērtējumam nākotnē ar inovatīvām metodēm pirmo reizi veikti sezonālās sukcesijas un ekologiiskās kvalitātes novērojumi laikā no 2014. gada aprīịa līdz oktobrim divos ezeros (Bābelītis, Gaiḷezers), divos karjeros (Bolderājas, Sauriešu), kā arī Vecāķu pludmalē, paralēli veicot paraugu ievākšanu pikoplanktona, nanoplanktona un planktona ciliātu populāciju tālākai izpētei.

Paraugi ievākti reizi mēnesī seklūdens zonā 1 metra dziḷumā. Ciliātu grupas fiksācijai izmantoja Lugola šķīdumu. Katrs no 35 paraugiem tika skatīts $25 \mathrm{ml}$ skaitīšanas kamerās, izmantojot DML Leica inverto mikroskopu. Ciliātu šūnu skaits un biomasas tika noteiktas pēc Utermola metodes (Utermöhl, 1958 cit. pēc Claessens, Prast, 2008). Daži no organismiem tika noteikti tikai līdz ǵintij, taču visi īpatṇi paraugos tika izmērīti un aprēķināta to biomasa, izmantojot ǵeometriskas formas (lode, elipse, konuss utml.). Sugu daudzveidība, dominances indekss, kā arī korelācija ar temperatūru, skābekli un 
biogēniem: $\mathrm{NO}_{2}-\mathrm{N}, \mathrm{NO}_{3}-\mathrm{N}, \mathrm{NH}_{4}-\mathrm{N}, \mathrm{PO}_{4}-\mathrm{P}, \mathrm{P}_{\text {kop. }}$, $\mathrm{N}_{\mathrm{kop}}$. un $\mathrm{Chl}$ a, noteikti izmantojot PRIMER 6 datu apstrādes programmu (Clarke, Gorley, 2006).

Apsekoto ūdenstilpju elektrovadītspējas mērījumi norāda, ka tie pieder pie seklūdens cietiem ezeriem, jo to elektrovadītspēja pārsniedz 165 mikroS/cm. Attiecībā uz skābekḷa režīma izmaiņām sezonālā aspektā tikai Gaiḷezerā vasaras/rudens periodā iezīmējas tā deficīts (zem 4,0 ml/1). Ar biogēno vielu dinamiku īpaši atšķiras Sauriešu karjers - $\mathrm{NH}_{4}$ jonu koncentrācija vidēji ir vairāk kā 2 reizes lielāka salīdzinot ar Gaiḷezeru un Bābelī̌sa ezeru, bet salīdzinājumā ar Bolderājas karjeru un Vecāḳu jūrmalu - vairāk kā 8 reizes. Vēl krasākas slāpekḷa jonu $\mathrm{NO}_{2}$ un $\mathrm{NO}_{3}$ koncentrāciju atškirības no pārējām apsekotām ūdenstilpnēm arī iezīmējas tieši Sauriešu karjerā.

Ciliātu sezonālā dinamika pozitīvi korelē ar ūdens temperatūru, populāciju skaita maksimumu sasniedzot vasaras periodā. Izdalot 3 izmēru grupas 16-30 $\mu \mathrm{m}, 30-50 \mu \mathrm{m}$ un > $50 \mu \mathrm{m}$, iezīmējas organismu izmēru grupu dinamika, vidēji sezonā sastādot nanofrakciju (16-30 $\mu \mathrm{m})$ 38\%, 30-50 $\mu \mathrm{m}$ 47\% un > $50 \mu \mathrm{m}-15 \%$. Ciliātu taksonu daudzveidībā kā apsekotajos ezeros, tā karjeros iezīmējas līdzības. Tā visaugstākais sastopamības biežums ir Strombidium, Strobilidium, Lohmaniella, Halteria, Vorticella, Cyclidium ğints sugām. Vecāķu stacijā kā tipiskas Baltijas jūras sugas papildus sastopamas Tintinnidae dzimtas sugas un autotrofā ciliāta - Mesodinium rubrum, kurai novērota izteikta masveida savairošanās jeb t.s."ziedēšana".

Veicot klastera analīzi ar sezonas vidējiem abiotiskiem un biotiskiem parametriem var secināt, ka Sauriešu karjers kā ūdenstilpe nav piemērots izmantot kā pilsētvides references ūdenstilpi, bet tāds varētu būt Bolderājas karjers, kuram iezīmējas zema eitrofikācijas slodze salīdzinājumā ar Bābelīša ezeru un Gaiḷezeru, kā arī ar Vecāķu jūrmalas peldvietu. 


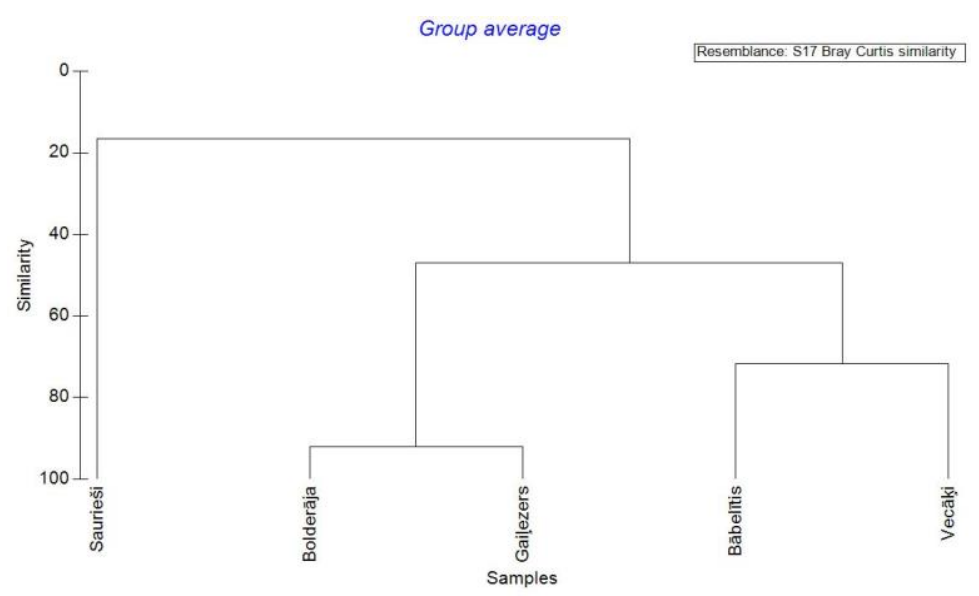

Darbs izstrādāts ESF projekta Nr. 2013 / 0060 / 1.1.1.2.0 / 13 / 1DP / APIA / VIAA / 041 „Jaunas zinātniskas grupas izveide urbānās dabas vides kvalitātes pētijumiem” (2013-2015) ietvaros.

\section{Izmantotā literatūra:}

Claessens, M., Prast, M. 2008. Concentration of fixed plankton samples via settling: how long is long enough?- Journal of planconic research 1, 57-64

Clarke, KR, Gorley, RN, 2006. PRIMER v6: User Manual/Tutorial. PRIMER-E, Plymouth.

Fenchel, T. 1987. Ecology of Protozoa. Science Technical, Madison, Wisconsin

Laybourn-Parry, J. 1992. Protozoan Plankton Ecology. Chapman Hall, London

Pfister, G., Auer, B., Arndt H. 2002. Pelagic ciliates (Protozoa, Ciliophora) of different brackish and freshwater lakes a community analysis at the species level.- Limnologica 32, 147-168

Sládeček, V. 1973. System of water quality from the biologicalpoint of view. Arch. Hydrobiol., Beih. Ergebn. Limnol. 7: I-IV, 1-218.

Utermöhl, H., 1958. Zur Vervollkommnung der quantitativen Phytoplankton-Methodik. Mit. int. Ver. theor. angev. Limnol., 19, 100-124

Van Wichelena, J., S. Johanssonb, L., Vanormelingena, P., A.J. Declerckd, S., Lauridsenb, T., De Meesterc, L., Jeppesenb, E., Vyvermanaa, W. 2013. Planktonic ciliate community structure in shallow lakes of lowland Western Europe.- European Journal of Protistology 49, 538-551

Xu, R., Cronberg, G. 2010. Planktonic ciliates in Western Basin of Lake Ringsjön, Sweden: community structure, seasonal dynamics and long-term changes.- Protistology 6 (3), 173-187

Zou, Q., Lu, Z., Li, Ch., Li, Y., Huang, P. 2013. Seasonal Pattern of Planktonic Ciliates in a Subtropical Shallow Urban Lake .- Current Research Journal of Biological Sciences 5(5), 210-219 


\section{ZIVJU MAZUḶU BAROŠANĀS EKOLOG̣IJA BURTNIEKU EZERĀ 2014. GADA VASARAS SEZONĀ \\ Marta DIEVIN̦A $^{1 *}$, Matīss ŽAGARS ${ }^{1}$ \\ ${ }^{1}$ Vides risinājumu institūts \\ *e-pasts: marta.dievina@gmail.com}

Zivs ontoǵenētiskās attīstības gaitā viens no svarīgākajiem posmiem ir mazuḷa stadija. Tās gaitā zivju mazuḷi intensīvi barojas un to barošanās ekologiija un savstarpējā zivju sugu mijiedarbība būtiski atšḳiras no vēlākām ontoǵenētiskās attīstības fāzēm. Šì pētījuma mērḳis bija izpētīt dominējošo zivju sugu mazuḷu barošanās ekoloǵiju un savstarpējo mijiedarbību Burtnieku ezerā.

Zivju mazuḷu paraugu ievākšana tika veikta 2014. gada 28. - 31. jūlijā. Paraugi ievākti izmantojot zinātnisko zvejas trali (4x2m; acs izmērs 4mm). Tralēšana veikta naktī un dienā, ezera atklātā ūdens teritorijā. Visi iegūtie zivju paraugi tika sašķiroti pēc sugām, īpatņi tika nosvērti un nomērīti. Tika ievākti visu zivju sugu īpatņu kuņǵu paraugi. Kungǵu satura analīzē noteikta barības objektu taksonomiskā piederība līdz zemākajam iespējamajam taksonam, barības objekti nosvērti un/vai saskaitīti. Turpmākā analīze tika veikta datiem par dominējošo zivju sugu mazuḷiem asari, zandarti, plauži un raudas. Lai noskaidrotu, cik lielā mērā pārklājas minēto zivju sugu mazuḷu barības objektu izvēle, tika aprēḳināts Šoenera diētu pārklāšanās indekss (Schoener's niche overlap index) (Schoener, 1970).

Kopumā asaru, zandartu, plaužu un ruduḷu mazuḷu kuṇgos pēc barības objekta sastopamības biežuma 71,2\% dominēja zooplanktons, 10,5\% zoobentoss un 4,2\% zivis. Savukārt pēc biomasas kungóos visvairāk bija sastopamas zivis $(1,1 \mathrm{~g})$, zooplanktons $(0,8 \mathrm{~g})$ un zoobentoss $(0,5 \mathrm{~g})$. Zivju kā barības objektu dominance pēc biomasas skaidrojama ar to lielo svaru attiecībā pret zooplanktona organismu nelielo individuālo svaru.

Analizējot asaru mazuḷu kuṇgus, noskaidrots, ka pēc procentuālā barības objektu sastopamības biežuma dominēja zooplanktons $(52,2 \%)$, zoobentoss $(19,4 \%)$ un zivis $(1,5 \%)$. No zooplanktona zivju kuṇgos gan pēc sastopamības biežuma, gan pēc biomasas dominēja Daphnia spp., Cyclops spp., Chydorus sphaericus. Tas skaidrojams ar konkrēto zooplanktona taksonu dominanci Burtnieku ezerā, kā arī ar faktu, ka Daphnia spp organismi ir salīdzinoši lieli, līdz ar to tiem ir lielāka enerǵêtiskā vērtība. Šis novērojams sakrīt arī ar citos pētījumos iegūtajiem rezultātiem par zivju mazuḷu barošanās paradumiem līdzīga ekoloǵiskā tipa ezeros, respektīvi, mērenās joslas seklos, eitrofos ezeros (Ginter et al., 2012). No zoobentosa gan pēc sastopamības biežuma, gan pēc biomasas dominē Chironomidae kāpuri, kas skaidrojams ar faktu, ka no asaru mazuḷiem pieejamajiem mikrozoobentosa organismiem Burtnieku ezerā dominē Chironomidae kāpuri.

Analizējot zandartu mazuḷu kuṇǵus, noskaidrots, ka pēc procentuālā barības objektu sastopamības biežuma dominēja zooplanktons $(62,2 \%)$ un zivis $(15,6 \%)$. No zooplanktona zivju kuṇǵos gan pēc sastopamības biežuma, gan 
pēc biomasas dominēja Leptodora kindtii, kas nav starp dominantajiem zooplanktona taksoniem Burtnieku ezerā. Tas norāda uz to, ka zandartu mazuḷi barojas selektīvi ar L. kindtii. To var skaidrot ar L. kindtii salīdzinoši lielajiem ķermeṇa izmēriem, līdz ar to šiem organismiem ir lielāka enerǵētiskā vērtība salīdzinot ar citiem izmērā mazākiem zooplanktona organismiem (Wetzel, 2001). Arī citos pētījumos L. kindtii minēts kā viens no dominatajiem zandartu mazuḷu barības objektiem (Ginter et al., 2011). Novērojums, ka dą̣a no zandartu mazuḷiem barojas ar zivīm norāda uz to, ka tie pakāpeniski pārslēdzas uz pieaugušām zivīm raksturīgiem barības objektiem.

88.9\% plaužu mazuḷu kuṇgós konstatêts zooplanktons. Gan pēc sastopamības biežuma, gan pēc biomasas dominē Chydorus sphaericus un Daphnia spp. Konkrēto zooplanktona taksonu dominance skaidrojama ar to lielo sastopamības biežumu Burtnieku ezerā.

Analizējot raudu mazuḷu kuṇǵus, noskaidrots, ka pēc procentuālā barības objektu sastopamības biežuma dominēja zooplanktons $(95,4 \%)$ un zoobentoss $(16,3 \%)$. No zooplanktona gan pēc sastopamības biežuma, gan pēc biomasas dominē Chydorus sphaericus, Daphnia spp. Tas skaidrojams ar konkrēto zooplanktona taksonu lielo blīvumu ezerā un salīdzinoši lielajiem ķermeņa izmēriem. No zoobentosa gan pēc sastopamības biežuma, gan pēc biomasas dominē Chironomidae kāpuri. Tas līdzīgi kā citu zivju sugu gadījumos skaidrojams ar minētā zoobentosa taksona lielo sastopamības biežumu Burtnieku ezerā.

No iegūtajiem datiem secināms, ka plēsīgo zivju mazuḷi (asari) barojas ar tām pašām zooplanktona sugām, ar ko karpveid̄̄go zivju mazuḷi (plauži, raudas). Veicot Šoenera diētu pārklāšanās indeksa aprēḳinus, iegūti rezultāti, kas tomēr neliecināja par ekoloǵiski būtisku diētu pārklāšanos vasaras sezonā. Šie rezultāti tika salīdzināti ar citu pētnieku darbiem par zivju mazul̦u barošanos (Mehner et al., 1996; Ginter et al., 2012). Tie uzrādīja līdzīgu ainu, ka vasaras sezonā zivju barošanās diētu pārklāšanās ir ekoloǵiski nebūtiska, savukārt rudenī šī pārklāšanās ir ekologiski būtiska. Šì iemesla dēḷ no pieejamajiem datiem tika aprēḳināts Šoenera diētu pārklāšanās indekss arī rudens sezonai. Iegūtie rezultāti liecināja, ka rudenī asaru un plaužu/raudu mazuḷu starpā ir ekoloǵiski būtiska diētu pārklāšanās. Minētā būtiskā zivju mazuḷu barošanās pārklāšanās rudenī skaidrojama ar kraso zooplanktona biomasu samazināšanos un zivju metabolisma aktivitātes pieaugumu rudens sezonā (Scheffer, 2004).

Tā kā kontrolzvejas ietvaros konstatēts, ka Burtnieku ezerā dominē ekoloǵiski un komerciāli mazvērtīgākās karpveidīgās zivis, tas nozīmēe ka tās mazuḷu attīstības stadijā konkurē par barības resursiem ar vērtīgo, plēsīgo zivju mazuḷiem. Šāda konkurence ilgtermiņā var negatīvi ietekmēt plēsīgo zivju, piemēram, asaru, populāciju Burtnieku ezerā. Tāpēc ir svarīgi pētīt dažādu zivju sugu mazuḷu savstarpējās mijiedarbības, jo tas ḷauj labāk spriest par ekologiiskajiem procesiem ūdens ekosistēmās.

Kopumā secināms: a) ka zivju mazuḷi barojas ar organismiem, kuriem Burtnieku ezerā ir liels sastopamības biežums un kuri ir salīdzinoši lieli savos individuālajos ķermeņa izmēros; b) ka plēsīgo (asaru, zandartu) un karpveidīgo (plaužu, raudu) mazuḷu starpā pastāv ekoloǵiski nebūtiska starpsugu konkurence pēc barības resursiem 
vasaras sezonā, bet piebilstams, ka rudens sezonā šĩ konkurence asaru un plaužu/raudu mazuḷu starpā ir ekolog̣iski būtiska. Š̀i konkurence mazuḷu stadijā starp karpveidīgajām un plēsīgajām zivīm iespējams var negatīvi ietekmēt plēsīgo zivju daudzumu Burtnieku ezerā.

\section{Izmantotā literatūra:}

Ginter K., Kangur K., Kangur A., Kangur P., Haldna M. 2011. Diet patterns and ontogenetic diet shift of pikeperch, Sander lucioperca (L.) fry in lakes Peipsi and Võrtsjärv (Estonia). - Hydrobiologia, 660: 79-91 pp.

Ginter K., Kangur K., Kangur A., Kangur P., Haldna M. 2012. Diet niche relationships among predator and prey fish species in their early life stages in Lake Võrtsjärv (Estonia). - Journal of Applied Ichthyology, 28: 713-720 pp.

Mehner T., Schultz H., Bauer D., Herbst R., Voigt H., Benndorf J. 1996. Intraguild predation and cannibalism in age-0 perch (Perca fluviatilis) and age-0 zander (Stizostedion lucioperca): Interactions with zooplankton succession, prey fish availability and temperature. - Finnish Zoological and Botanical Publishing, 33: 353-361 pp.

Scheffer M. 2004. Ecology of Shallow Lakes. Dordrecht: Kluwer Academic Publisher, 357pp.

Schoener, T. W., 1970. Non-synchronous spatial overlap of lizards in patchy habitats. Ecology 51, 408-418.

Wetzel R. G. 2001. Limnology. Lake and River Ecosystems. Third Edition. California: Elsevier academic Press, 1006 pp. 


\section{DEMONSTRĀCIJU SAIMNIECĪBAS „LIELKRŪZES” VIRSZEMES ŪDEṆU KVALITĀTES NOVĒRTĒJUMS}

\section{Dāvis GRUBERTS ${ }^{1}$, Jana PAIDERE ${ }^{2 *}$}

${ }^{1}$ Daugavpils Universitātes Ķìmijas un geogrāfijas katedra, Parādes iela 1, Daugavpils

${ }^{2}$ Daugavpils Universitātes Dzīvības zinātṇu un tehnoloğiju institūts, Parādes iela 1a, Daugavpils

*e-pasts: jana.paidere@du.lv

Virszemes ūdeṇu kvalitātes pētījumi demonstrāciju saimniecībā „Lielkrūzes” tika veikti 2014. gada jūlijā. Pētījuma mērḳis bija noskaidrot, kāda ir virszemes ūdeņu ḳīmiskā un bioloǵiskā kvalitāte, iztekot tiem no saimniecības zivju dīķu sistēmas, un noskaidrot kā tā mainās lejup pa straumi meliorācijas grāvī, kura augštecē un vidustecē iepriekš veikti rekultivācijas darbi (izveidotas sedimentācijas un filtrācijas zonas, veikta gultnes izlīkumošana u.t.t.).

Ūdens paraugi biogēnu ( $\mathrm{P}_{\text {kop. }}$ un $\mathrm{N}_{\text {kop. }}$ ) un bioḳīmiskā skābekḷa (BSP) noteikšanai tika ievākti un ūdens fizikāli ķīmisko parametru mērījumi ar $H A C H$ DS5 daudzparametru zondi veikti saimniecības lielākajā zivju dīḳ̂̄ (1 vieta) un no tā iztekošajā meliorācijas grāvī (5 vietas). Saimniecības lielākajā zivju dīḳ̂̄ vienlaicīgi tika ievākts arī zooplanktons virsējā ūdens slānī 0,5 m dziḷumā (papildus arī meliorācijas grāvī, kas tek no meža) ar Apšteina planktona tîkliṇu $(64 \mu \mathrm{m})$, izfilttrējot 100 un 501 ūdens. Ar Seki disku $(25 \mathrm{~cm} \varnothing)$ tika noteikts ūdens caurspīdīgums.. Makrozoobentosa paraugi atbilstoši standartmetodikas prasībām (LVS 240: 1999) tika ievākti meliorācijas grāvī, kas iztek no saimniecības lielākā zivju dīķa, pirms paraugu ievākšanas veicot arī straumes ātruma mērījumus, izmantojot digitālos hidrometriskos spārniņus Swoofer 3000. Biogēni ( $\mathrm{P}_{\text {kop }}$ un $\mathrm{N}_{\mathrm{kop}}$ ) tika analizēti DU Vides ķīmijas laboratorijā, atbilstoši metodikai, izmantojot plūsmas injekcijas analīzes iekārtu FIAlab 2500. Ievākto ūdens paraugu $\mathrm{BSP}_{5}$ analīzes tika veiktas DU Ekologijas institūtā 2014. gada 17. un 22. jūlijā atbilstoši standartmetodēm. Izšḳ̂idušã skābekḷa mērījumi tika veikti ar mēraparātu YSI 5000 Dissolved Oxygen meter.

Iegūtie rezultāti liecina, ka no „Lielkrūžu” centrālā/lielākā zivju dīḳa iztekošie ūdeṇi vasaras mazūdens periodā ir salīdzinoši zemas kvalitātes, par ko liecina gan to fizikālie un ķīmiskie parametri, gan bioloǵiskie rādītāji (trofijas pakāpe, saprobitātes indekss). Piemēram, izšḳīdušā skābekḷa koncentrācija lielākajā zivju dīḳī $2 \mathrm{~m}$ dziḷumā ir tuvu izsīkumam $\left(0,51 \mathrm{mg} \mathrm{l}^{-1}\right)$, bet biogēnu $\left(\mathrm{P}_{\mathrm{kop}}\right.$ un 
$\mathrm{N}_{\text {kop }}$ ) koncentrācijas dīķa virsējā ūdens slānī atbilst eitrofu līdz stipri eitrofu ezeru rādītājiem ( $\mathrm{P}_{\mathrm{kop}}-0,9$ $\mathrm{mg} \mathrm{l}^{-1}, \mathrm{~N}_{\mathrm{kop}}-1,52 \mathrm{mg} \mathrm{l}^{-1}$ ) (Dodds, 2002). Kā arī lielais zooplanktona organismu skaits 1614 tūkst. eks. $\mathrm{m}^{-3}$ un eitrofas vides indikatorsugu klātbūtne (Brachionus angularis, Trichocerca rousseleti, Anuraeopsis fissa.) atbilst stipri eitrofiem un eitrofiem ezeru ūdeņiem (Bērziņš \& Pejler, 1989) jeb barības vielām bagātiem duḷ,ķainiem kultūrā audzētu zivju dīķiem (Cottenie et al., 2001). Virzienā no rekultivētā grāvja iztekas uz ieteku Gaujā samazinās makrozoobentosa zoocenožu saprobitātes indekss (2,3 - pie iztekas, 2,2 - lejpus filtrācijas zonas, 2,1. - izlīkumotā posma vidū). Tas norāda uz to, ka rekultivētajā grāvī tekošais ūdens ir vāji piesārņots līdz piesārņots, kas atbilst $\beta$-mezosaprobajai zonai (Cimdiņš, 1995), kāa arī uz šo ūdeņu daḷēju pašattīrīšanos un bioloğiskās kvalitātes uzlabošanos rekultivētajā grāvja lejtecē. Salīdzinot rekultivēto grāvja posmu, nerekultivētajā posmā ūdens kvalitāte no jauna samazinās, kas galvenokārt izpaužas kā kopējā N koncentrācijas un BSP $_{5}$ rādītāju pieaugums lejup pa straumi. Tas norāda uz nepieciešamību veikt turpmākus renaturalizācijas darbus arī atlikušajā grāvja daliā.

\section{Izmantotā literatūra:}

Bērziņš, B., Pejler, B. 1989. Rotifer occurrence and trophic degree. Hydrobiologia, 172: 171-180.

Cimdiņš, P. (red.), 1995. Praktiskās hidrobioloǵijas rokasgrāmata. Upju piesārṇojuma bioloğiskās analīzes metodes. Rìga, Vide, 71 lpp.

Cottenie, K., Nuytten, N., Michels, E., De Meester, L. 2001. Zooplankton community structure and environmental conditions in a set of interconnected ponds. Hydrobiologia, 442: 339-350.

Dodds, K. W. 2002. Freshwater Ecology. Concepts and Environmental Applications. Academic Press, 569 pp.

LVS 240:1999. Ūdens kvalitāte - mazo upju biologiskās kvalitātes operatīva novērtēšana pēc makrozoobentosa cenožu saprobitātes indeksa. Latvijas valsts nacionālais standarts (spēkā no: 1999.11.17.). 


\title{
LATVIJAS UN LIETUVAS UPJU HIDROMORFOLOG̣ISKĀ NOVĒRTĒJUMA SALĪDZINĀJUMS
}

\author{
Jolanta JĒKABSONE \\ Latvijas Universitātes Geogrāfijas un Zemes zinātņu fakultāte \\ *e-pasts: jolanta.jekabs@gmail.com
}

Saskaņā ar Ūdens struktūrdirektīvu 2000/60/EC līdz 2015. gadam ir jāpanāk vismaz laba ūdensobjektu ekoloǵiskā kvalitāte. Ekologiskā kvalitāte jānosaka, izmantojot biologiskos (fitoplanktons, bentoss, makrofîti), ķīmiskos un hidromorfologiskos (antropogēnās ietekmes pakāpe) rādītājus. Ūdens struktūrdirektīva nosaka, ka upes un ezeri tiek apsaimniekoti ņemot vērā sateces baseina, nevis administratīvās robežas, tāpēc starpvalstu sadarbība pārrobežas ūdeņu apsaimniekošanā ir īpaši svarīga. Latvijā prasības hidromorfologiskajam novērtējumam ir iekḷautas MK noteikumos Nr. 858. „Noteikumi par virszemes ūdensobjektu tipu raksturojumu, klasifikāciju, kvalitātes kritērijiem un antropogēno slodžu noteikšanas kārtību", kas nosaka, ka pie hidromorfologiskajiem rādītājiem pieder hidrologiskais režīms, upes nepārtrauktība un morfologiskie apstākḷi.

Eiropā kopumā ir vairāk, kā 20 metožu upju hidromorfologiiskā stāvokḷa noteikšanai (Birk, 2003). Vācija, Lielbritānija un Francija ir attīstījušas kompleksas metodes hidromorfoloğijas novērtēšanai (Kamp et al., 2004; Raven et al., 1998) un Lielbritānijā izstrādātā River Habitat Survey (RHS) metode tika izvēlēta kā labākā iespējamā visas Eiropas mērogā izmantojamā metode. Visas trīs Baltijas valstis pieder pie 15. ekoreǵiona ar līdzīgām slodzēm un ietekmēm. Latvija un Lietuva gandrīz vienādi dala divus lielus upju baseinu apgabalus: Ventas baseinu (56\% no kopèjās platīibas ir Latvijā) un Lielupes baseinu (50\%). Lielai daḷai abu baseinu upju augštece atrodas Lietuvā, bet lejtece Latvijā, tāpēc harmonizēta kvalitātes novērtējuma sistēma ir īpaši būtiska. ES dalībvalstīm, izmantojot dažādas metodes, ir jāpanāk vienots pārrobežu ūdensobjektu novērtējums. Ir izstrādātas vairākas pieejas, lai harmonizētu dažādas hidromorfologiiskā novērtējuma sistēmas (Langhans, 2013), bet to veikt nav iespējams, ja metodes ir radītas dažāaiem mērķiem vai nesaskan ar Eiropas standartu EN 14614: 2004.

Kopumā Ventas un Lielupes baseinu apgabalos tika novērtēti 40 upju posmi 29 upēs izmantojot Latvijā līdz šim visbiežāk lietoto RHS metodi un Lietuvā izmantoto Lietuvas hidromorfoloǵisko indeksu (Upiu hidromorfologinio indekso, HMIu). Izmantojot RHS tiek rēķināti divi indeksi: HMS (antropogēnās ietekmes pakāpe) un HQA (dabisko pazīmju izplatība). Novērotās HQA vērtības Ventas 
un Lielupes baseinos variē no 8 līdz 67 punktiem (standartnovirze 17.7, vidējā vērtība 43 punkti). Vidējā HMS vērtība ir 17.4 punkti, kas ir robežās no 0 līdz 50 (standartnovirze 16.9). Saskaņā ar HQA novērtējumu, vairāk kā puse jeb 58\% no analizētajiem upju posmiem pieder pie labas vai augstas kvalitātes klases, 17\% ir vidēja kvalitāte un 24\% posmu kvalitāte vērtējama kā zema. Pēc HMS indeksa lielākā daḷa upju posmu ir ievērojami pārveidoti (32\%) vai dominē nepārveidota vide (22\%), 27\% no pētītajiem upju posmiem ir dabiski vai gandrīz dabiski, un $26 \%$ ir redzami pārveidota vide.

Saskaņā ar HMIu indeksu, 48\% no pētāmajiem upju posmiem pieder pie augstas vai labas kvalitātes klases, 37\% pieder pie vidējas kvalitātes un 17\% pie sliktas kvalitātes. L,oti sliktai kvalitātes klasei nepieder neviena no Latvijas upēm.

1. tabula. Latvijas un Lietuvas hidromorfologiijas metožu salīdzinājums

\begin{tabular}{|c|c|c|}
\hline & RHS & HMIu \\
\hline Parametru skaits & 17 & 5 \\
\hline Novērojuma vietas & Gultne un piekrastes zona & Gultne un piekrastes zona \\
\hline Posmu garums & Visiem upju tipiem $500 \mathrm{~m}$ & $\begin{array}{l}\text { Atkarībā no parametra un baseina } \\
\text { laukuma, } 50 \mathrm{~m}-5 \mathrm{~km}\end{array}$ \\
\hline Kvalitātes klašu skaits & 4 (HQA) and 5 (HMS) & 5 \\
\hline References apstākḷi & $\begin{array}{lr}\text { Gandrīz dabiski } & \text { upju } \\
\text { daudzveidības } & \text { un } \\
\text { nepārveidotības apstākḷi } & \end{array}$ & Optimāli apstākḷi zivīm \\
\hline Aprēķinu metode & $\begin{array}{l}\text { Vērtību summa katram } \\
\text { nosakāmajam parametram, kas } \\
\text { izteikta kvalitātes klasēs HMS } \\
\text { un HQA indeksiem }\end{array}$ & $\begin{array}{l}\text { Vērtību summa katram } \\
\text { parametram, kas izteikta kā } \\
\text { ekologiskās kvalitātes indekss }\end{array}$ \\
\hline Hidrologiskais režīms & Tikai ūdens plūsmas dinamika & Tikai ūdens plūsmas dinamika \\
\hline Upes nepārtrauktība & Tikai 500 m robežās & $\begin{array}{l}\text { Atkarībā no baseina laukuma, } 50 \\
\text { m-5 km }\end{array}$ \\
\hline $\begin{array}{l}\text { Morfoloǵiskie } \\
\text { apstākḷi }\end{array}$ & $\begin{array}{l}\text { Tikai gultnes substrāts un } \\
\text { struktūra, krastu struktūra }\end{array}$ & Tikai gultnes substrāts un struktūra \\
\hline
\end{tabular}


Lietuvas indekss vienlīdz labi korelē gan ar HQA (0.688, p=0.01), gan HMS $(-0.733, p=0.01)$. Korelācija starp HMA un HQA ir negatīva $(-0.561, \mathrm{p}=0.01)$, jo abi RHS metodes indeksi ir radīti dažādu ietekmes veidu noteikšanai. Trim no četriem HMIu indikatoriem ir statistiski ticama pozitīva korelācija ar HMS indeksu: gultnes struktūra $(0.901, \mathrm{p}=0.01)$, piekrastes veǵetācija $(0.565, \mathrm{p}=0.01)$, gultnes substrāts $(0.308, \mathrm{p}=0.05)$. Korelācija ar hidroloǵisko režīmu ir vājāka (-0.104) un nav statistiski ticama.

Abas izmantotās metodes ir l̦oti atšķirīgas un rezultāti ir grūti salīdzināmi, jo tiek izmantots dažāds kvalitātes klašu skaits (1. tabula). Neviena no apskatītajām metodēm bez pārveidošanas nav piemērota izmantošanai monitoringā. RHS metodes pozitīvās puses ir salīdzinoši lielais parametru skaits, atbilstība Eiropas standartam un nepiesaiste kādam noteiktam upju tipam vai reǵionam. Kā RHS metodes lielākie mīnusi tās izmantošanai monitoringā ir minams laikietilpīgums (vidēji divas stundas) un vienotas kvalitātes klases trūkums (upju kvalitāti raksturo divi indeksi). Iepriekšējos pētijumos tika secināts, ka RHS metode ir piemērota izmantošanai Latvijas apstākḷıs (Briede et al., 2005). Šī pētijjuma rezultāti liecina, ka metode nav piemērota izmantošanai lēni plūstošās piejūras līdzenumu upēs, kas ir dabiski dziḷas un ar smilšainu un dabiski homogēnu gultni un kur nevar veidoties sēres vai citas gultnes pazīmes. Piemēram, Sventājā un Slocenes lejtecē. Lietuvas hidromorfologijas indekss ir radīts kā atbalsta rādīiājs zivju monitoringam un izmantoto parametru izvēle ir bijusi selektīva. Tas atbilst MK noteikumos izvirzìtajām prasībām, bet neatbilst Eiropas standartam. Gultnes struktūras ciešā korelācija ar HMS liecina, ka HMIu indekss uzrāda morfolog̣isko degradāciju un cilvēku darbības ietekmi, nevis dabisko pazīmju daudzumu.

\section{Izmantotā literatūra:}

Birk, S. 2003. Review of European assessment methods for rivers and streams using Benthic Invertebrates, Aquatic Flora, Fish and Hydromorphology. Diploma thesis.

Briede, A., Springge, G., Skuja, A. 2005. The influence of hydromorphological feature on the quality of stream in Latvia. Verh. Internat. Verein. Limnol. 29: 1075 - 1079.

European Commission 2000. Directive of the European Parliamentand of the Council 2000/60/EC establishing a framework for community action in the field of water policy. European Commission PE-CONS 3639/1/00 REV 1, Luxembourg.

Kamp, U., Binder, W., Hölzl, K. 2007. River habitat monitoring and assessment in Germany. Environmental Monitoring and Assessment 127: 209-226. 
Raven, P.J., Holmes, N.T.H., Dawson, F.H., Everald, M. 1998. Quality assessment using River Habitat Survey data, Aquatic Conservation: Marine and Freshwater Ecosystems. (8), 477-499. 


\title{
RESNVĒDERA PURVUSPĀRES LEUCORRHINIA CAUDALIS (ODONATA: LIBELLULIDAE) IZPĒTE UN AIZSARDZĪBA LATVIJĀ
}

\author{
Mārtiņš KALNIN̦Š ${ }^{1,2 *}$ \\ ${ }^{1}$ AS "Latvijas Valsts meži", Vainodes iela 1, Rīga, LV-1004, Latvija \\ ${ }^{2}$ Latvijas Entomoloğijas biedrība, Kronvalda bulvāris 4, Rīga, LV-1586, Latvija \\ *e-pasts: m.kalnins@lvm.lv,martins.kalnins@biology.lv
}

Resnvēdera purvuspāre Leucorrhinia caudalis ir viena no Latvijā sastopamajām spāru sugām, kas tiek uzskatīta par apdraudētu sugu un ir iekḷauta dažāda līmeṇa sugas aizsardzību regulējošajos normatīvajos aktos (cf. Kalkman et al., 2010). Saskaņā ar Article 17 ziņojumu (Ziņojums Eiropas Komisijai par biotopu (dzīvotņu) un sugu aizsardzības stāvokli Latvijā (Novērtējums par 2007.-2012. gada periodu)) aizsardzības stāvokḷa vērtējums resnvēdera purvuspārei ir nelabvēlīgs un ir konstatēta negatīva aizsardzības stāvokḷa tendence. Par vairākiem ziṇojumā iekḷautajiem parametriem vērtējums balstīts, pamatojoties uz eksperta viedokli, vai arī nav datu vispār (piemēram, par sugas apdzīvoto mikrobiotopu, biotopu hidroķīmiskajiem parametriem). Dabas aizsardzības pārvaldes dabas datu pārvaldības sistēmā "OZOLS" ir reǵistrētas tikai atsevišķas, tajā skaitā neprecīzas sugas atradnes, līdz ar to nevar plānot un realizēt atbilstošu sugas atradņu aizsardzību. Plānojot saldūdeņu biotopu apsaimniekošanas pasākumus, netiek vērtēta piekrastes biotopu apsaimniekošanas nepieciešamība saistībā ar resnvēdera purvuspāres (un arī citu īpaši aizsargājamo spāru sugu) aizsardzību. Darba mērḳis ir apkopot informāciju par resnvēdera purvuspāres izpēti un aizsardzību Latvijā un sagatavot ieteikumus nepieciešamajiem aizsardzības pasākumiem.

Resnvēdera purvuspāre Latvijā visbiežāk konstatēta eitrofos ezeros, retāk diseitrofos ezeros un vecupēs (Kalniņš, 2008). Resnvēdera purvuspāres atradnēs eitrofos ezeros un vecupēs parasti ir vizuāli vidēji bagātīgs līdz bagātīgs, daudzveidīgs un sugām bagāts augājs. Parasti labi izveidojušās visas virsūdens, peldlapu un iegrimušo ūdensaugu - joslas. Pašlaik Latvijā resnvēdera purvuspāre ir konstatēta visā valsts teritorijā. Salīdzinot sugas vēsturiskos un mūsdienu izplatības datus, var secināt, ka ir samazinājies sugas novērojumu skaits, kas varētu liecināt par sugas populācijas samazināšanos Latvijā. Iespējams, ka sugas nevienmērīgā izplatība vairāk saistāma ar nevienmērīgo izpētes līmeni, nekā ar sugas faktisko izplatību (Kalniņš, 2012).

Resnvēdera purvspāres populācijas ietekmējoši faktori ir dabiskie ienaidnieki un svešzemju 
sugas, kolekcionēšana, ekstremāli laika apstāḳ̣i, indīgās vielas vidē un populāciju minimālais lielums. Tomēr visi šie faktori ir ar nezināmu vai zema līdz vidēja riska faktoru. Svešzemju sugām un populāciju minimālais lielums, iespējams, var būt arī augsta riska faktors. Sugas biotopa izzušana ir vidēja riska faktors, jo līdz šim konstatēta tikai atsevišḳās vietās. Līdzīgi novērtēta arī biotopu fragmentācija (atradṇu izolācija), dzīvotṇu apsaimniekošana (ūdenstilpju tīrīšana) un dzīvotṇu

piekrastes joslas neapsaimniekošana (aizaugšana). Tomēr šo faktoru kombinācijai var būt liela ietekme uz sugas populācijas stāvokli Latvijā.

Sugas aizsardzības plānā (Kalniņš, 2014) aprakstīti resnvēdera purvuspāres aizsardzības pasākumi likumdošanas un dabas aizsardzības plānošanas, sugas un tās dz̄ivotnes aizsardzības, izpētes un monitoringa jomās, kā arī informēšanas un izglītības jomā. Daļa no aprakstītajiem pasākumiem attiecināmi uz bezmugurkaulnieku vai pat sugu un biotopu aizsardzības jomu kopumā.

Darbs izstrādāts Latvijas vides aizsardzības fonda finansētā projekta Nr. 1-08/162/2014 "Sugas aizsardzības plāna izstrādāšana un ieviešanas uzsākšana resnvēdera purvuspārei Leucorrhinia caudalis" ietvaros.

\section{Literatūras saraksts:}

Kalkman V.J., Boudot J.-P., Bernard R., Conze K.-J., De Knijf G., Dyatlova E., Ferreira S., Jović M., Ott J., Riservato E., Sahlén G. 2010. European Red List of dragonflies. IUCN \& Publications Office of the European Union, Luxembourg: 28 pp.

Kalniņš M. 2008. Protected Aquatic Insects of Latvia - Leucorrhinia albifrons (Burmeister, 1839) and L. caudalis (Charpentier, 1840) (Odonata: Libellulidae). Latvijas Entomologs 45: 5-13.

Kalniņš M. 2012. Dragonflies (Odonata) of Latvia - history of research, bibliography and distribution from 18-th century until 2010. Latvijas Entomologs 51: 91-149.

Kalniņš M. 2014. Resnvēdera purvuspāres Leucorrhinia caudalis (CHARPENTIER, 1840) sugas aizsardzības plāns. Biedrība "Zaḷā upe", Sigulda: 1-71. 


\title{
FITOPLANKTONA INDIKATORU KLAŠU ROBEŽVĒRTĪBU IZSTRĀDE LATVIJAS PIEKRASTEI
}

\author{
Atis LABUCIS ${ }^{1 *}$, Ieva BĀRDA ${ }^{1}$, Iveta JURGENSONE ${ }^{1}$ \\ ${ }^{1}$ Latvijas Hidroekologijas institūts, Daugavgrīvas iela 8 \\ *e-pasts: atis.labucis@lhei.lv
}

Baltijas jūra ir viens no lielākajiem iesāḹūens baseiniem pasaulē. Tāpat Baltijas jūra un Rīgas līcis ir Latvijas videi svarīgas ekosistēmas un to aizsardzība un resursu ilgstoša izmantošana ir nozīmīgs uzdevums. Liela uzmanība tiek vērsta uz resursu ekonomisku metožu un instrumentu radīšanu, un ES Ūdens Struktūrdirektīva (2000/60/EK) paredz visām ES dalībvalstīm interkalibrēt (salīdzināt testēšanu) novērtēšanas metodes un radīt robežvērtîbas pārejas un piekrastes ūdeṇu kvalitātes klasēm, kas bija šī pētījuma mērķis. Kā viens no galvenajiem, ar eitrofikāciju saistītajiem bioloǵiskajiem elementiem, ir fitoplanktons, tā taksonomiskais sastāvs, biomasa un tās rādītājs hlorofils „a”, kas iekḷauti Baltijas valstu monitoringa programmu sastāvā (HELCOM, 2014).

Balstoties uz iepriekšējiem pētījumiem (DANCEE, 2004, Aigars et al., 2008) un citu Baltijas jūras valstu pieredzi, tika izstrādātas klašu robežvērtības vasaras hlorofila ,a” koncentrācijai un vasaras fitoplanktona biomasai. Hlorofila „a” koncentrācijas references vērtība Rīgas līcim tika noteikta $2 \mathrm{mg}$ $\mathrm{m}^{-3}$, pārejas ūdeņiem $-1.8 \mathrm{mg} \mathrm{m}^{-3}$ un atklātajai Baltijas jūras piekrastei $-1.2 \mathrm{mg} \mathrm{m}^{-3}$. Kopējās fitoplanktona biomasas references vērtības atklātajai Baltijas jūrai netika noteiktas vēsturisko datu trūkuma dẹl, savukārt Rīgas līcim un pārejas ūdeņiem tās aplēstas, attiecīgi 175 un $155 \mathrm{mg} \mathrm{m}^{-3}$. N̦emot vērā šīs references vērtības, tika aprēkinātas un noteiktas robežvērtības piecām kvalitātes grupām.

Lai sekmgi šīs izstrādātās robežvērtības izmantotu ūdeņu ekolog̣iskās kvalitātes noteikšanai ES Ūdens struktūrdirektīvas 2000/60/EK ietvaros, nepieciešams regulārs monitorings. Diemžēl līdzšinējā fitoplanktona monitoringa paraugošanas prakse šajās ūdenstilpēs nevar nodrošināt fitoplanktona un tā rādītāja - hlorofila „a” izmantošanu. Ierosināts, ka fitoplanktona un hlorofila „a” monitoringa minimālajam vākumu skaitam Rīgas līcī un Baltijas jūras piekrastē jābūt: vismaz 1 reizi mēnesī janvārī, februārī un martā, vismaz 2 reizes mēnesī aprīlī, maijā, jūnijā, jūlijā, augustā un septembrī, vismaz 1 reizi mēnesī oktobrī novembrī un decembrī. Bet, lai precīzāk izsekotu pavasara fitoplanktona masveida savairošanās attīstībai, aprīlì un maijā paraugi būtu jāievāc vienreiz nedēḷā. 


\section{Izmantotā literatūra:}

Aigars, J., Müller-Karulis, B., Martin, G., Jermakovs,V. 2008. Ecological quality boundary-setting procedures: the Gulf of Riga case study. Environmental Monitoring and Assessment 138 (1-3), 313 - 326. DOI 10.1007/s10661-007-9800-5

DANCEE project No M:128/023-004 “Transposition and Implementation of the EU Water Framework Directive in Latvia", 2004. Technical Report No. 1A "Typology of surface water and procedure for characterization of waters", $80 \mathrm{p}$.

[http://www.varam.gov.lv/eng/projekti/es_vides_projekti/?doc=3315].

HELCOM, 2014. Manual for Marine Monitoring in the COMBINE Programme of HELCOM. Part C Programme for monitoring of eutrophication and its effects. Anex C4 and C6. 


\section{VIENDIENİ̌̆U SUGU IZPLATĪBA VENTAS UN LIELUPES BASEINU APGABALOS SAISTIIBĀ AR ŪDENS FIZIKĀLI-ĶĪMISKAJIEM PARAMETRIEM \\ Dāvis OZOLIN̦Š ${ }^{1 *}$, Agnija SKUJA ${ }^{1}$, Elga PARELE ${ }^{1}$, Ilga KOKORĪTE ${ }^{1}$, Jolanta JĒKABSONE ${ }^{1}$, Laura GRĪNBERGA ${ }^{1}$ \\ ${ }^{1}$ LU Biologijas institūts, Hidrobiologijas laboratorija, Salaspils, Miera iela 3 \\ *e-pasts:davis@email.lubi.edu.lv}

Bentisko bezmugurkaulnieku paraugi tika ievākti 2013. gada oktobrī un novembrī projekta "Upju monitorings un lauksaimnieku vides aptauja Lielupes un Ventas upju baseinu apgabalos (LiVe River Basins)" ietvaros. Kopā tika ievākti 26 paraugi Ventas baseinā un 34 Lielupes baseinā; datu analīzei izmantoti dati par viendienītēm. Viendienītes Ephemeroptera ir otra ekoloǵiski jutīgākā ūdens kukaiṇu kārta pēc strautenēm Plecoptera, tomēr viendienītes atšķirībā no strautenēm, apdzīvo visus saldūdeņu biotopus (Bauernfeind, Soldán, 2012). Vairāk kā puse Lielupes baseina upju atrodas īpaši nitrātjutīgajā teritorijā, kurā lauksaimnieciskās darbības rezultātā ir paaugstināts nitrātu piesārņojums (Anon., 2009a) savukārt Ventas baseinā pie nitrātjutīgām teritorijām tiek pieskaitīts tikai viens ūdens objekts (Anon., 2009b).

Makrozoobentosa paraugi tika ievākti ar hidrobioloǵisko tīkliṇu (rāmja izmērs 0,25 x 0,25 m, tīkliņa acs izmēru 0,5 mm). Paraugu ievākšanai tika izvēlēti brienami mazo upju posmi un vidēju un lielu upju piekrastes (līdz 0,8 m dziļumam). Katrā upes posmā tika ievākti pieci atkārtojumi atbilstoši grunts substrāta procentuālajam segumam, kā arī piecu minūšu laikā ievākts kvalitatīvs paraugs, ar pinceti no dažādiem substrātiem nolasot bentosa organismus. Laboratorijā tika veikta paraugu šķirošana un sugu identificēšana. Vairums viendienīšu tika noteiktas līdz sugas līmenim. Ūdens fizikāli-ķīmisko parametru analīzes tika veiktas trīs sezonās - 2013. gada ruden̄̄ un 2014. gada pavasarī un vasarā.

Viendienīšu kāpuri konstatēti visos apsekotajos upju posmos, to sugu skaits paraugā svārstījās no 1 līdz 12. Apsekotajos Lielupes un Ventas baseinu upju posmos tika konstatētas 27 viendienīšu sugas no 7 dzimtām: Baetidae: Baetis muticus, B. atrebatinus, B. fuscatus, B. rhodani, B. vernus, B. niger, Centroptilum luteolum, Cloeon dipterum; Caenidae: Caenis horaria, C. luctuosa, C. robusta, C. macrura; Ephemerellidae: Ephemerella mucronata, Eurylophella karelica; Ephemeridae: Ephemera 
danica, E. lineata, E. vulgata, Ecdyonuridae: Ecdyonurus spp., Heptagenia coerulans, H. fuscogrisea, H. sulphurea; Leptophlebidae: Habrophlebia lauta, Leptophlebia vespertina, Leptophlebia marginata, Paraleptophlebia cincta, P. submarginata; Pothamanthidae: Potamanthus luteus.

Viendienı̄šu sugas $B$. atrebatinus, B. vernus, E. mucronata un Ecdyonurus spp. tika konstatētas tikai Ventas upes baseinā, bet C. robusta, H. coerulans, L. marginata un P. cincta - Lielupes baseinā. Lēnā tecējuma un augsto slāpekḷa savienojumu koncentrāciju dēl, Lielupes baseina upēs ir mazāks viendien̄išu sugu skaits nekā Ventas baseinā. Viendienīšu suga $C$. dipterum raksturojama kā tolerantākā pret organisko piesārņojumu, jo tās sastopamas upēs ar paaugstinātām toksisko nitrītjonu koncentrācijām.

\section{Izmantotā literatūra:}

Anon. 2009a. Lielupes upju baseina apgabala apsaimniekošanas plāns 2010. -2015. gadam. VSIA Latvijas Vides, ǵeologijas un meteorologijas centrs: 97 lpp.

Anon.2009b. Ventas upju baseina apgabala apsaimniekošanas plāns 2010. -2015. gadam. VSIA Latvijas Vides, ǵeologijas un meteorologijas centrs: 102 lpp.

Bauernfeind E., Soldán T. 2012. The Mayflies of Europe (Ephemeroptera). Apollo Books. Denmark: $782 \mathrm{p}$. 


\section{ZIVJU SASTOPAMĪBA LATVIJAS ŪDEN̦OS BALTIJAS JŪRĀ UN RĪGAS JŪRAS LĪCI \\ Māris PLIKŠS}

Pārtikas drošības, Dzīvnieku veselības un Vides zinātniskais institūts „,BIOR”, Daugavgrīvas iela 8, LV 1048, Rìga

*e-pasts: maris.plikss@bior.gov.lv

Baltijas jūra ir neliels Atlantijas okeāna iesāḷūdeņu baseins. Tā tiek uzskatīta arī par jaunu jūru, kas veidojusies pēc Baltijas ledus perioda, un tās ǵeoloǵiskajā vēsturē ir bijusi savienota ar Atlantijas okeānu (arī savienota mūsdienās), gan arī iespējams ar Ziemeḷu ledus okeāniem (Ignatius et al., 1981). Tās viena no būtiskām īpatnībām ir vertikālā ūdeṇu stratifikācija (Ehlin, 1981). Zivju fauna iesālajāa Baltijas jūrā arī ir samērā jauna un sugas ir maz mainījušās saistībā ar to izcelsmes vietām. Ihtiofauna ietver gan jūras, gan arī saldūdens izcelsmes zivju sugas. Jūras zivis ir ienākušas Baltijas jūrā no Ziemeḷjūras aptuveni pirms 4000-8000 gadiem, sākot no siltās un iesālāas Litorīna jūras perioda. Acīmredzot līdz mūsdienām saglabājās tikai tās sugas, kuras bija spējīgas pārdzīvot saldūdens Ancila ezera periodu un līdz ar to Joldijas jūras reliktu skaits ir neliels, piemēram: četragu buḷlzivs (Triglosis quadricornis) (Ojaveer et al., 1981). Nākamajā Litorīna jūras periodā, kas raksturojās ar krietni siltāku un par 5-6psu sāḷāku vidi nekā mūsdienās, Baltijas jūrā ienāca Arktikas un Atlantijas boreālā kompleksu zivis (Ignatiues et al., 1981; Paaver, Lõugas, 2003). Kopš tā laika jūra kḷuvusi nelabvēlīga tieši jūras zivīm, un, ņemot vērā pašreizējos nelielos un mainīgos jūras sāḷuma apstākḷus, jūras zivis atrodas pastiprināta fizioloǵiskā stresa stāvoklī, kas ir par iemeslu to lēnākai augšanai un lielākai paaudžu ražības mainībai, salīdzinot ar radniecīgajām sugām Atlantijas okeānā un tam pieguḷošajās citās jūrās. Baltijas jūras iesāḷais režīms ir arī par iemeslu tam, ka jūras ihtiofauna ir samērā nabadzīga, tajā dominē tikai dažas jūras sugas: menca, brētliṇa, reņǵe un plekste, respektīvi, eirihalīnas sugas. Savukārt tās sugas, kuru vairošanās ir iespējama pie sāļumiem, kas raksturīgi tipiskai jūras videi (sāḷums ap 30psu), centrālajā Baltijā var ieceḷot spontāni vai nu barības meklējumos vai ar straumēm un tiek uzskatīti par maldu viesiem. Zemais sāḷums un tā samazināšanās rietumu-ziemeḷaustrumu virzienā nosaka to, ka jūrā virzienā uz ziemeḷiem, it īpaši piekrastē, palielinās saldūdens zivju sugu skaits (Ojaveer et al., 1981).

Darba galvenais mērḳis ir sniegt vēsturisko pārskatu par Latvijas ūdeṇu Baltijas jūrā un Rīgas jūras līcī sastopamajām zivju sugām, to izmaiṇām un izmaiṇas nosakošajiem iespējamajiem faktoriem. 
Pārskats ir balstīts uz pieejamo literatūru sākot no 1771. gada. Mūsdienu sugu sastāva apzināšanai izmantotas bentisko tralējumu (martā un novembrī 1990.-2014. gados); pelaǵisko tralējumu (maijā un oktobrī 2005.-2013. gados), piekrastes tīklu zvejas Salacgrīvā, Daugavgrīvā, Lapmežciemā, Jūrkalnē un Papē (1992.-2014. gados) un bentisko piekrastes zivju mazulu (1985. - 2000. gadi) veiktajām uzskaitēm un tajās konstatēto zivju sugu sastāva analīzi, kā arī uz zvejnieku ziņojumiem par noķertajām retajām zivju sugām.

Pirmie ziņojumi par ihtioafaunas sastāvu, kuri būtu attiecināms uz Latvijas jūras vidi, tika atzīmēti 18. gadsimta otrā pusē un 19. gadsimtā (Fischer, 1771; Fischer, 1991; Kawall, 1858; Möbius, Heincke, 1883; Seidlitz, 1877). Pirmajos sugu sarakstos (Fisher, 1971; Kawall, 1858) nav sniegtas norādes par zivju sastopamību saldūdeņos vai jūrā, izṇemot atsevišķas norādes. Tāpēc, mēs jūras zivju faunā ietvērām tās sugas, kuras atzīmētas jūras ūdeṇos vēlākajās publikācijās. Pirmie sugu saraksti, raugoties no mūsdienu viedokḷa, ir samērā nepiln̄̄gi. Domājams, ka tajos galvenokārt ietvertas zivis, kuras tika zvejotas cilvēku patēriņam, ar kurām tirgojās, kā arī sugas, kurām varbūt nebija tirgus vērtība, bet bija sastopamas masveidā un no pārējām sugām atšḳīrās ar īpatnējām morfoloǵiskām pazīmēm, piemēram, stagari. Dažām zivīm, kā reṇgei, lasim, sīgai, kā atsevišḳas sugas tika uzskaitītas mūsdienās aprakstītās pasugas, rases vai pat formas (Fisher, 1991; Kawall, 1858). Latvijas zivju sugu sastāvs, kas ietver arī Baltijas jūru, principā tika izveidots 20. gadsimta 30-tajos gados un, kopš tā laika arī nav būtiski mainījies (Grosse, 1933; Mansfelds, 1936; Schneider, 1928). To lielā mērā sekmēja zivsaimniecības zinātnes pirmsākumi Latvijā un labi attīstîtā informācijas ievākšana un par jaunu zivju noķeršanas gadījumiem publicēšana „Zvejniecības Vēstnesī” un „Zvejniecības Mēnešrakstos”. Līdz mūsdienām kopš 1920. - 1930. gadiem diadromo un saldūdens zivju sugu kopējais skaits gandrīz nav main̄̄jies, bet jūras zivju sugu skaits uzrāda palielināšanās tendenci (1.tabula).

Anadromās zivis varētu iedalīt divās nosacītās grupās: pirmkārt, zivis, kuras izplatītas jūrā un vairojas Latvijas saldūdeṇos (upes nēǵis - Lampetra fluviatilis, lasis - Salmo salar, taimiņš - Salmo trutta, sīga - Coregonus lavaretus, salaka - Osmerus eperlanus, vimba - Vimba vimba) un otrkārt, zivis, kuru vairošanās Latvijas saldūdeṇos nav dokumentāli apstiprināta. Pie pēdējām pieskaitāmas tādas sugas, kā jūras nēǵis - Petromyzon marinus, lapreṇǵe - Alosa fallax un kaze - Pelecus cultratus, kuras regulāri, bet nelielā skaitā sastopamas Latvijas piekrastē. Domājams, ka šo sugu sastopamības biežums ir atkarīgs no to vairošanās sekmības tuvākajos nārsta upes - Nemūnā un Vislā. Atsevišķi būtu izdalāma Baltijas store (Acipenser oxyrinchus), kursa dabīgā populācija Baltijas jūrā, domājams, ir 
izzudusi. Latvijā pēdējais noķeršanas gadījums reǵistrēts 1963. vai 1994. gadā pie Jūrmalas (M. Vītiņš pers. kom.), lai gan 1996. gadā store tika noķerta Igaunijā pie Muhu salas (Paaver, 1997). 2011 un 2013. gadā nelielu un iezīmētu storu noḳeršanas gadījumi pie Liepājas un Daugavgrīvas ( $\overline{\mathrm{E}}$. Urtāns per. kom.) ir saistīti ar storu reintrodukcijas programmu, kura 2007. gadā ir uzsākta Vācijā un Polijā Odras upē. Šo projektu ir akceptējis HELCOM un tajā piedalās arī Latvija (http://helcom.fi/helcom-atwork/projects/sturgeon-rehabilitation-pg).

Arī saldūdens zivju sugu skaits Latvijas ūdeņo nav būtiski mainījies (1. tabula), tomēr atzīmējami vairāki interesanti ar saldūdens zivju sastopamību jūrā saistīti aspekti:

- 2006. gadā 6km uz dienvidiem no Liepājas tika noķerta barbe - Barbus barbus (E.Urtāns pers. kom.). Barbe Latvijas zivju sarakstā parādījās 1937. gadā, kad tās noķeršana tika konstatēta pie Liepājas un attiecināta uz Bārtas upes lejteci (Mansfeld, 1939). Vēlākajos pēckara sugu sarakstos (Nikolajev, 1953; Sloka, 1956) tā tika iekḷauta Latvijas faunas sastāvā. Tomēr, pamatojoties uz visaptverošiem Latvijas upju ihtiofaunas pētījumiem, barbe nav konstatēta nevienā no upēm un tāpēc nav iekḷaujama Latvijas upju zivju sarakstā (Birzaks, 2012). Varētu pieņemt, ka barbe līdz Liepājas piekrastei nonākusi no tuvāko dienvidu upju - Sventājas vai Nemūnas baseiniem Lietuvā. Jāatzīmēe ka arī Gdaņskas līča piekrastē barbe ir reti sastopama suga, jo tās areāla ziemeḷu robežu ietver tieši Baltijas jūras dienviddaḷas upju baseinus (Skóra, 1996; Miller, Loates, 2006).

- Jūras ūdeņu zivju sarakstos jau kopš 1930. gadiem ir iekḷautas tādas sugas, kāa platgalve (Cottus gobio), bārdainais akmengrauzis (Noemacheilus barbatulus) un akmengrauzis (Cobitis taenia), tomēr nevienā no piekrastes zivju uzskaitēm š̄is sugas pēdējos 25 gadus nav konstatētas. Ja tās tomēr ir sastopamas, tad tas varētu būt tieši upju grīvās vai to tuvumā.

- Publikācijās līdz pagājušā gadsimtā vidum atzīmēts, ka Latvijas ūdeņos Baltijas jūrā un Rīgas jūras līcī tādas zivis kā plicis (Blicca bjoerkna), plaudis (Abramis brama), un ķīsis (Gymnocephalus cernua) ir reti sastopamas (Mansfelds, 1936; Nikolajev, 1953). Turklāt Baltijas jūras piekrastē no karpveidīgajām zivīm sastopamas tikai anadromās vimba un kaze. Kā rāda kontrolzvejas, tad pēdējās desmitgadēs šo sugu skaits piekrastē ir ievērojami palielinājies. Kā viens no šādu izmaiṇu iemesliem varētu būt saistīts ar 
jūras eitrofikācijas palielināšanos, kas savu maksimumu sasniedza 1970. gadu beigās un 1980. gadu sākumā (Gustafsson et al., 2012).

Jūras zivju kopējā sugu skaita palielināšanos pēc Otrā pasaules kara noteica arī zvejas pakāpeniska pārorientēšanās no piekrastes uz atklāto jūru, ko veicināja traḷu zvejas attīstība. Tas būtiski palielināja nozveju kopējos apjomus un arī paplašināja apzvejojamo areālu. Jauni noķeršana gadījumi tika reǵistrēti atklātās jūras zivīm, kuras, domājams, iemigrējušas no Rietumbaltijas, kā anšovam (Engraulis encrasicolus), saidai (Polachius virens) un pikšai (Melanogrammus aeglefinus) (Nikolajev, 1953). Jūras zivju, it īpaši reto un maldu viesu, noḳeršanas gadījumu skaita palielināšanos kopš 1990. gadu sākuma ir veicinājusi arī samērā intensīvā zinātniskā izpēte, ko nodrošināja regulārās zinātniskās bentiskas un pelaǵisko traḷu uzskaites, kā arī ikgadèjās piekrastes zivju kontrolzvejas 7-9 vietās gar visu Latvijas piekrasti ar zinātniskajiem tīkliem un piekrastes zivju mazuḷu vadiṇiem. Turklāt regulāri tika saņemta arī informācija no zvejniekiem - novērotājiem, ar̄i makšķerniekiem, kuri informēja par retu zivju noķeršanu. Baltijas jūrā un Rīgas jūras līcī Latvijas ūdeņos kopumā mūsdienās ir reǵistrētas 37 jūras zivis, no kurām 26 ir bentiskās un 11 pelaǵiskās sugas (1. tabula). 12 sugas no jūras zivīm ir uzskatāmas par maldu viesiem, kuri ieceḷo Austrumbaltijā no Dienvid- vai Rietumbaltijas, bet 25 sugām vairošanās areāls atrodas mūsu ūdeņos.

Kopš 1990. gadu beigām jūras zivju skaits tieši Latvijas ūdeṇos palielinājies par trīs sugām, kuru atradnes ir dokumentētas: merlangs (Merlangius merlangus) - atradumi 2012. g. martā bentisko zivju mazuḷu uzskaitē uz dienvidiem no Liepājas un piekrastes kontrolzvejā 2014. g., novembrī pie Pāvilostas, āķdegunis (Agonus cataphractus) - viena eksemplāra piezveja 2001. gadā mencas tīklu zvejā un apaḷais jūrasgrundulis (Neogobius melanostomus). Apaḷo jūrasgrundulis ir invazīva suga, kas Baltijas jūrā ienākusi no Melnās vai Kaspijas jūras. Tagad to var uzskatīt par aklimatizējušos sugu. Pirmo reizi tā konstatēta Gdaņskas līcī Polijas piekrastē (Skóra, Stolarski, 1993), bet Latvijā pirmo reizi noḳerta pie Liepājs 2004. gadā (Minde 2007). Jau 2005. gadā apaļais jūrasgrundulis parādījās Latvijas piekrastē Rīgas jūras līcī, kaut arī pirmais noḳeršanas gadījums Pērnavas līci ir datēts ar 2002. gadu (Ojaveer, Špilev, 2003). Pašlaik tas sastopams gar visu Latvijas piekrasti.

No jūras zivīm kopš 2000. gada ir ievērojami palielinājies citzemju pelaǵisko un bento-pelaǵisko zivju skaits. Šādu izmaiṇu iemesli varētu būt saistīti ar Baltijas jūras un jo īpaši Gotlandes ieplakas hidrolog̣iskā režīma maiṇu: 
- Pēc 1981. gada ir samazinājušies Ziemeljjūras/Kategata lielie ieplūdumi jeb tā saucamie barotrofiskie ieplūdumi (Matthäus, 2006), kuru rezultātā sāḷie un aerētie Ziemeḷjūras/Kategata ūdeṇi nodrošināja pilnvērtīgu Baltijas jūras ieplaku dziḷūdens slāṇu aerāciju un ūdens apmaiṇu.

- Kopš 2002. gada ir būtiski palielinājusies barokīnisko (vasaras) ieplūdumu intensitāte, kuri raksturojas ar augstāku ieplūstošo ūdeṇu temperatūru un mazāku skābekḷa saturu un sāḷmumu. (Matthäus et al., 2008). Lieli baroklīniskie ieplūdumi tika reǵistrēti 2002., 2006 un 2009/2010.gados (Nausch et al., 2014), kā rezultātā tiem, sasniedzot Gotlandes ieplaku, ūdens sāḷuma palielinājās, bet skābekḷa koncentrācijas nedz samazinājās dziḷajā aktīvajā slānī 80-120m (Bērziņš, 2011; Bērziṇšs, 2014). Acīmredzot šīs izmaiņas ir sekmējušas tādu zivju kā merlanga, anšova un makreles (Scomber scomber) parādīšanos mūsu ūdeņos. Ja vēl pirms 20-30 gadiem par šo zivju noķeršanu l,oti reti tika saṇemta informācija no zvejniekiem, tad kopš 2000. gada zinātniskajās traḷu uzskaitēs ir reǵistrēti 28 anšovi, 5 merlangi un makrereles. Jāatzīmē, ka iepriekšējos 30 gadus zinātniskajās uzskaitēs netika konstatēts neviens no šo sugu ippatniem.

- Ar skābekli nabadzīgo jūras dziḷūdens platību palielināšanā. Pēdējo 115 gadu laikā hipoksija (rajoni ar skābekḷa saturu mazāku par 2 $\mathrm{ml} \mathrm{1}^{-1}$ ) Bornholmas un Gotlandes ieplakās palielinājusies no $5000 \mathrm{~km}^{2}$ līdz vairāk nekā $60000 \mathrm{~km}^{2}$. Domājams, ka antropogēnais piesārṇojums saistībā ar barības vielu noplūdi jūrā ir galvenais hipoksijas areāla palielināšanās faktors (Carstensen, 2014). Tomēr, barības vielu daudzums jūrā palielinājās kopš 1950-tajiem gadiem, sasniedzot maksimumu ap 1980. gadu, bet pēc tam līdz mūsdienām samazinājās. Šo samazināšanos galvenokārt noteica piekrastes notekūdeņu attīrīšana, jo upju notece sarukusi tikai par aptuveni 10\% (Gustafsson et al., 2012). Neskatoties uz šo samazināšanos temperatūras palielināšanās, kas varētu būt saistīta ar globālajām klimata izmaiņām un Baltijas jūras austrumdaḷā arī ar baroklīnisko ieplūdumu intensitātes palielināšanos, tomēr ierobežoja skābekḷa apstākḷu uzlabošanos Baltijas jūrā. Augstāk minētie procesi ir cieši saistīti ar saldūdens/upju noteci jūrā, kura savukārt raksturojas ar sauso un mitro periodu maiņu. Vistiešākā ietekme šiem procesiem varētu ietekmēt, piemēram, jūras vēdzeles (Enchelyopus cimbrius), kura 
sastopama dziḷāk par 80m, skaita dinamiku. Pēdējās desmitgadēs Gotlandes ieplakā jūras vēdzeles piezveja salīdzinot ar 1980. gadiem ir samazinājusies vairākkārtīgi un 2000.-2014.gados zinātniskajās uzskaitēs kopā noķertas tikai 111 zivis.

Papildus tam, reto jūras zivju skaits un biežāki konstatēšanas gadījumi varētu būt saistīti ar Baltijas jūras galvenās plēsējzivs populācijas samazināšanos kopš 1980. gadu vidus (ICES, 2013). Kā zināms, menca var būtiski ietekmēt citu zivju populāciju skaitu (Casini et al., 2012).

Atsevišķu Ziemeḷjūras plēsejzivju ienākšana Latvijas piekrastē, domājams, ir arī atkarīga no šo zivju krājuma stāvokḷa un, palielinoties to populācijai Ziemeljūrā, būtu lielāka varbūtība veikt tālas barošanās migrācijas, sekojot teiksim Rietumbaltijas reṇǵei tās nārsta migrācijā no Ziemeljūras uz Rīgenas salas piekrasti. Tas varēt attiektos, piemēram, uz zobenzivi (Xiphias gladius). Kopš 1800. gada Latvijas piekrastē reǵistrēti 24 noḳeršanas gadījumi, pēdējie no kuriem pie Užavas 1993. gadā un Ziemupē 2007. gadā (Plikšs, Aleksejevs, 1998; Anon., 2007). Polijas piekrastē 1993. un 1995.gados līdzīgi ir noḳertas 3 zobenzivis, kas norāda, ka Baltijas jūrā dotajā gadā ir ienācis pat neliels zobenzivju bars (Skóra, 1996).

Pēdējos gados nav atkārtotu noķeršanas gadījumu biezlūpainai kefalei (Chelon labrosus), kuras viens eksemplārs tika noķerts pie Salacgrīvas 1980. gadā (Pilāts et al., 1988) un labrakam (Dicentrachus labrax), kura trīs eksemplāri tika noḳerti 1993. gadā Rīgas jūras līcī pie Daugavgrīvas un Salacgrīvas (Plikšs, Aleksejevs, 1998).

Vēsturiskajos sugu sarakstos (Kawall, 1758) uz Latvijas ūdeņiem pieminēta divu eksotisku sugu noķeršana pie Liepājas: zāǵzivs (Pristis pristis) un jūraszirdziņš (Hippocampus hippocampus). Vēlākajos Latvijas zivju sugu sarakstos tās netika iekḷautas, jo tika uzskatītas par apšaubāmām. Lai arī zāǵzivs ir sastopama iesāḷūdeņos un pat var veidot saldūdens populācijas, tomēr š̄is zivis tālas migrācijas neveic, un to pašreizējie areāli ir uz dienvidiem no Ziemeḷjūras dienvidrietumiem. Pie kam, arī Skandināvijas, Ziemeljūras un Baltijas jūras zivju sarakstos šīs sugas pat 100 gadus pēc Kawall (1758) publikācijas nav minētas (Nilsson, 1852; Seidlitz, 1877; Collet, 1905).

Kopumā, domājams, ka nav iespējams izdalīt vienu noteicošo faktoru, kas noteiktu to vai citu sugu klātbūtni Latvijas ūdeņos Baltijas jūrā. Sugu sastāva izmaiņas nosaka vides faktoru un zivju savstarpējo attiecību mijiedarbības. Tāpēc, kā varētu mainīties jūras zivju sugu sastāvs nākotne ir grūti prognozēt. Ir liela varbūtība tikt atrastām jūras zivīm, kuras lai arī reti, tomēr atkārtoti ir konstatētas Gdaņskas līcī, piemēram, jūraslīdaka (Molva molva), jūrasgaiḷi (Trigla sp.), jūrasmēle (Solea vulgaris) 
un aloza (Alosa alosa) (Skóra, 1996). Potenciāli varētu būt aptuveni 70 jūras zivju sugu, kuras sastopamas Skagerakā un Kategatā un vēl nav konstatētas pie mums (Musse, 1999; Curry-Lindahl, 1985). Sugu skaita ziṇā, tās varētu būt galvenokārt mencveidīgās, asarveidīgās un plekstveidīgās zivis.

\section{Izmantotā literatūra:}

Anon., 2007. Ziemupē izskalo milzu zobenzivi. Vides Vēstis, 9(102):50-54.

Auziņš, V. 1925. Zivkopība. Zvejnieku Vēstnesis, 8/9: 76-77.

Bērziṇš, V. 2011. Ūdens sāḷuma un skābekḷa koncentrācijas dinamika Gotlandes ieplakas centrālās daḷas starpslānī pēdējos 50 gados. LU 69 zinātniskā conference „Latvijas ūdeṇu vides pētījumi un aizsardzība”, Rīga: 10-13.

Bērziņš, V. 2014. Dažu vides faktoru ietekme uz skābekḷa koncentrācijas dinamiku Baltijas jūras centrālās dalıas dziḷajos slāṇos. LU 69 zinātniskā konference „Latvijas ūdeņu vides pētījumi un aizsardzība”, Rīga: 6-8.

Birzaks, J., Aleksejevs, E., Strūgis, M. 2011. Occurence and sistribution of fish in rivers of Latvia. Proc.Latvian Acad. Scien., 65(3/4): 57-66.

Carstensen, J., Andersen, J.H., Gustafsson, B.G., and Conley, D.G., 2014. Deoxygenation of the Baltic Sea during the last century. PNAS, 111(15):5628-5633.

Casini, M., Blenckner, T., Möllmann, C., Gårdmark, A., Lindegren, M., Llope, M., Kornilovs, G., Plikshs, M., Stenseth N.C. 2012. Predator transitory spillover induces trophic cascades in ecological sinks. PNAS, 109(21):8185-8189.

Collet, R. 1905. Meddelelser om Norges Fiske i Aarene 1884-1901. Christiania, I Kommission hos Jacob Dybwad, 173p [in Norvegian].

Curry-Lindahl, K. 1985. Våra fiskar. Havs-och sötvattensfiskar i Norden och ovrig Europa. P.A.Nordstedt \&Söners Förlag, Stockholm, 528p [In Swedish].

Ehlin, U. 1981. Hydrology of the Baltic Sea. In: The Baltic Sea (Ed. A. Voipio). Elsevier Oceanography Series, 30: 123-133.

Fischer, J. B. 1778. Versuch einer Naturgeschichte von Livland. Verlegt Johann Gottlob Immanuel Vreitkopf.Leipzig: 113-128 [in German].

Fischer, J. B. 1791. Versuch einer Naturgeschichte von Livland. 1. Aufl. Königsberg: 240-261 [in German].

Grosse, A. 1933. Pisces. Zivis. Latvijas mugurkaulaino noteicējs Latvijas dabaszin. Biedr. Izdev: 196-218.

Gustafsson, B.G., Schenk, F., Blenckner, T., Eilola, K., Meier, H. E. M. Müller-Karulis, B., Neumann, T., Ruoho-Airola, T., Savchuk, O.P., Zorita, E. 2012. Reconstructing the development of Baltic sea eutrophication 1850-2006. Ambio, 41(6):534-548.

ICES, 2013. Report of the Baltic Fisheries Assessment Working Group (WGBFAS). ICES Headquarters, 10-17 April 2013. ICES CM 2013/ACOM:10.

Ignatius, H., Axberg, S., Niemistö, L. and Winterhalter, B. 1981. Quaternary geology of the Baltic Sea. In: The Baltic Sea (Ed. A. Voipio). Elsevier Oceanography Series, 30: 54:104. 
Kawall, H. 1858. Fische in Kurland und an den Küsten der dasselbe begränzenden Ostsee, mit Berücksichtigung von Livland. Inland (Wochenschrift für Liv-, Est- und Kur land) , Jahrg. 23. 1858. Dorpat. 33: 534-536, 35: 561-568, 36: 579-583 [in German].

Mannsfeld, W. 1939. Mitteilunngen zur Fishfauna Lettlands. III Korresp. Bl. Naturforscher -Ver. zu Riga, 63: 43-47 [in German].

Mansfelds, V. 1936. Latvijas zivis. Latvijas zeme daba un tauta. N. Maltas un P. Galenieka red., II sēj. Latvijas daba. Valtera un Rapas akc. sab. apgāds, Rīga: 489-519.

Matthäus, W. 2006. The history of investigations of salt water inflows into the Baltic Sea-from the early beginning to recent results. Meereswissenschaftliche Berichte, 65, 73p.

Matthäus, W., Nehring, D., Feistel, R., Nausch, G., Mohrholz, V., Lass, H.U. 2008. The inflow of highly saline water into the Baltic Sea. In Feistel, R., Nausch, G., Wasmund, N. (Eds.), State and Evolution of the Baltic Sea, 1952 - 2005. A Detailed 50-Year Survey of Meteorology and Climate, Physics, Chemistry, Biology, and Marine Environment. John Wiley \& Sons, Inc., Hoboken: 265-309.

Miller, P.J., Loates, M.J. 2006. Euroopa Kalad. Eesti Entsulopeediakirjastus, AS, Tallinn, 288pp [in Estonoan].

Minde, A. 2007. Uzmanību - apaļais jūrasgrundulis. Latvijas Zivsaimniecības gadagrāmata. Zivju Fonds, Rīga:89-92.Pirmo reizi - Liepāja-2004, RJL- 2005.gadā

Möbius, K., Heincke F. 1883. Die Fische der Ostsee. Paul Parey, Berlin, 1883, 206p [in German].

Muus, B.J., Nielsen, L.G., Dahlstrøm, P., Nyström, B.O. 1999. Sea Fish. Scandinavian Fishing Year Book, $338 \mathrm{pp}$.

Naush, G., Feistel,R., Naumann M., Mohrholz, V. 2014. Water Exchange between the Baltic Sea and the North Sea, and conditions in the Deep Basins. HELCOM Baltic Sea Environment Fact Sheets. Online. [Published 3.11.2014], http://www.helcom.fi/baltic-sea-trends/environment-fact-sheets/.

Nikolajev, I.,I. 1953. Fish species composition of Latvian SSR. Proceedings of Latvian division of VNIRO. Academy of Science of Latvian SSR, Riga, 1: 5-27 [Николаев И.И., 1953. Видовой состав рыб Латвийской ССР. Труды Латвийского отделения ВНИРО, выпуск I. Рига, Издательство Академии наук Латвийской ССР: 5-27] [in Russian)].

Nilsson, S. 1852. Skandinavisk Fauna. Fjerde Delen: Fiskarna. Lund, 280p [in Swedish].

Ojaveer, E., Gaumiga, R., 1995. Cyclostomes, Fishes and Fisheries. In: Ecosystem of the Gulf of Riga 1920 and 1990 (Ed. E.Ojaveer). Estonian Academy Publishers, Tallinn: 212-267.

Ojaveer, E., Lindroth, A., Bagge, O., Lehtonen, H., Toivonen, J.1981. Fish and fisheries. In: The Baltic Sea (Ed. A. Voipio). Elsevier Oceanography Series, 30: 275-350.

Ojaveer, H., Špilev, H. 2003. Round goby, Neogobius melanostomus (Pallas). In: Fishes of Estonia (Eds. Ojaveer, E. Pihu and T.Saat). Estonian Academy Publisher, Tallinn:336-337.

Paaver, T. 1997. Atlandi tuur - Eesti haruldasim kala 1996 - suure kala aasta. Eesti Loodus'97:191-193 [in Estonian].

Paaver, T., Lõugas, L. 2003. Origin and history of the fish fauna in Estonia. In: Fishes of Estonia (Eds. Ojaveer, E. Pihu and T.Saat). Estonian Academy Publisher, Tallinn: 28-46.

Pilāts, V., Zvirgzds, A., Lipsbergs, U. 1988. Pirmais reǵistrētais biezlūpainās kefales - Chelon labrosus (Risso, 1826) - sastapšanas gadījums Latvijas piekrastē. Retie augi un dzīvnieki, Rīga: 37-43. 
Plikšs, M. 2003. Zivju sugu daudzveidība Baltijas jūrā un Rīgas jūras līcī. Latvijas Sarkanā grāmata. Retās un apdraudētās augu un dzīvnieku sugas. 5.sējums Zivis, Rāpuḷi, abinieki (G.Andrušaita red.). Rīga: 9-26.

Plikšs, M., Aleksejevs, E. 1998. Latvijas Zivis. Gandrs, Rīga, 304.lpp.

Schneider G. 1928. Die Seefischerei von Lettland und Estland, Handbuch der Seefischerei Nordeuropas. Bd.8.Die Seefisherei der skandinavischen und osteuropäischen Länderan, heft 6, E. Schweizerbart'sche Verlagsbuchhandlung, Stuttgart, 1928:1-34 [in German].

Seidlitz, G. 1877. Die Fische der Ostseeprovinzen Russlands. Fauna Baltika, Dorpat, 135p [in German].

Siliņš, J. 1936. Latvijas zivis. Jaunais zinātnieks nr.37.Valtera un Rapas akciju sabiedrības izdevums. Rīga: $861 \mathrm{pp}$.

Skóra, K., Stolarski, J. 1993. New species in the Gulf of Gdańsk. Biuletyn Morskiego Instytutu Rybackiego 1(128): 83.

Skóra, K.E., 1996. New and rare fish species from the Gulf of Gdansk [Nowe i rzadkie gatunki z rejonu Zatoki Gdańskiej]. Zoologica Poloniae 41 (Supplement:113-130 [in Polish].

Sloka, J., 1956. 1. klase Cyclostomata - apaḷmutes. 2. klase Pisces Zivis. Latvijas PSR dzīvnieku noteicējs 2.dal̦a (E.Taurina un E.Ozola red.). Latvijas Valsts izdevniecība, Rīga: 7-61 lpp.

Sloka, J., 1966. Apaḷmutes - Cyclostomata. Zivis - Pisces. In: Latvijas Dzīvnieki (Z. Spura red.). Zvaigzne, Rīga: 74-95.

1. tabula. Zivju sugu sastopamība Baltijas jūrā un Rīgas jūras līcī dažādos vēstures periodos

\begin{tabular}{|c|c|c|c|c|c|c|c|c|c|c|}
\hline Nr. & Suga & Nosaukums & Grupa & Statuss & 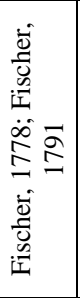 & 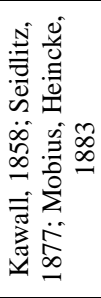 & 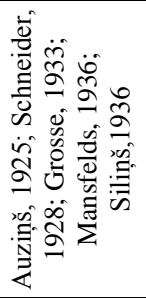 & 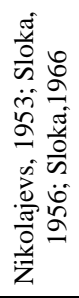 & 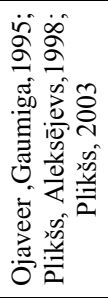 & $\stackrel{n}{\stackrel{n}{n}}$ \\
\hline \multicolumn{11}{|c|}{ Jūras zivis } \\
\hline 1 & Pristis pristis $(L)$. & zāğzivs & JB & $\mathrm{V}$ & & + & + & & & \\
\hline 2 & Clupea harengus membras $L$. & reṇge & JP & A & + & + & + & + & + & + \\
\hline 3 & Sprattus sprattus balticus (Schneider) & brētliṇa & JP & A & + & + & + & + & + & + \\
\hline 4 & Engraulis encrasicholus $(L)$. & anšovs & $\mathrm{JP}$ & $\mathrm{V}$ & & + & & + & + & + \\
\hline 5 & Belone belone (L.) & vējzivs & JP & A & + & + & + & + & + & + \\
\hline 6 & Gadus morhua callarias $(L)$. & menca & JB & A & + & + & + & + & + & + \\
\hline 7 & Melanogrammus aeglefinus $(L)$. & pikša & JB & $\mathrm{V}$ & & + & & + & + & + \\
\hline 8 & Merlangius merlangus $(L)$. & merlangs & $\mathrm{JB}$ & $\mathrm{V}$ & & & & & & + \\
\hline 9 & Pollachius virens $(L)$. & saida & JB & $\mathrm{V}$ & + & + & & + & + & + \\
\hline 10 & Enchelyopus cimbrius $(L)$. & jūrasvēdzele & JB & A & & + & + & + & + & + \\
\hline 11 & Spinachia spinachia $(L)$. & jūrasstagars & JP & A & & + & + & + & + & + \\
\hline 12 & Nerophis ophidion $(L)$. & čūskzivs & JP & A & & + & + & + & + & + \\
\hline 13 & Syngnathus typhle $L$. & adatzivs & JP & A & & + & + & + & + & + \\
\hline 14 & Hippocampus hippocampus $($ L.) & $\begin{array}{l}\text { īsdeguna } \\
\text { jūraszirdziňš }\end{array}$ & JP & $\mathrm{V}$ & & + & & & & \\
\hline 15 & Hyperoplus lanceolatus (Le Sauvage) & nigliṇš & JB & $\mathrm{A}$ & & + & + & + & + & + \\
\hline 16 & Ammodytes tobianus $(L)$. & tūbīte & JB & $\mathrm{A}$ & + & + & + & + & + & + \\
\hline
\end{tabular}




\begin{tabular}{|c|c|c|c|c|c|c|c|c|c|c|}
\hline Nr. & Suga & Nosaukums & Grupa & Statuss & 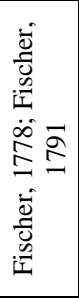 & 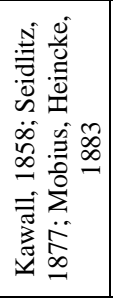 & 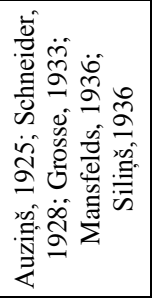 & 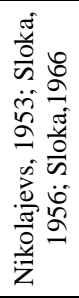 & 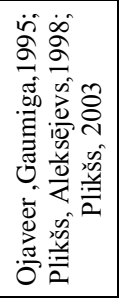 & $\stackrel{n}{\stackrel{i}{d}}$ \\
\hline 17 & Scomber scomber $L$. & makrele & JP & $\mathrm{V}$ & + & + & + & + & + & + \\
\hline 18 & Xiphias gladius $L$. & zobenzivs & JP & $\mathrm{V}$ & & + & + & + & + & + \\
\hline 19 & Gobius niger $L$. & $\begin{array}{l}\text { melnais } \\
\text { jürasgrundulis }\end{array}$ & $\mathrm{JB}$ & $\mathrm{A}$ & & + & + & + & + & + \\
\hline 20 & Pomatoschistus microps (Kröyer) & jūrasgrundulis & $\mathrm{JB}$ & $\mathrm{A}$ & & + & + & + & + & + \\
\hline 21 & Pomatoschistus minutus (Pallas) & $\begin{array}{l}\text { mazais } \\
\text { jūrasgrundulis }\end{array}$ & JB & $\mathrm{A}$ & & + & + & + & + & + \\
\hline 22 & Gobiusculus flavesens (Fabr.) & $\begin{array}{l}\text { divplankumu } \\
\text { jūrasgrundulis }\end{array}$ & $\mathrm{JB}$ & A & & + & & & + & + \\
\hline 23 & Neogobius melanostomus (Pallas) & $\begin{array}{l}\text { apaląis } \\
\text { jūrasgrundulis }\end{array}$ & JB & $\mathrm{AK}$ & & & & & & + \\
\hline 24 & Pholis gunellus $($ L.) & taukzivs & $\mathrm{JB}$ & $\mathrm{A}$ & & + & + & + & + & + \\
\hline 25 & Lumpenus lampretaeformis (Walb.) & lentzivs & $\mathrm{JB}$ & $\mathrm{A}$ & & + & + & + & + & + \\
\hline 26 & Zoarces viviparus $(L)$. & lucītis & $\mathrm{JB}$ & $\mathrm{A}$ & & + & + & + & + & + \\
\hline 27 & Chelon labrosus (Risso) & biezlūpu kefale & JP & $\mathrm{V}$ & + & & & & + & + \\
\hline 28 & Dicentrachus labrax $(L)$. & $\begin{array}{l}\text { labraks, } \\
\text { jūrasasaris } \\
\end{array}$ & JP & $\mathrm{V}$ & & & & & + & + \\
\hline 29 & $\begin{array}{l}\text { Myoxocephalus scorpius scorpius } \\
(\text { L.) }\end{array}$ & ziemel̦u buḷızivs & JB & A & + & + & + & + & + & + \\
\hline 30 & Taurulus bubalis (Euphrasen) & jūras dzeloṇgalva & JB & $\mathrm{A}$ & & + & + & + & + & + \\
\hline 31 & Triglopsis quadricornis $(L)$. & četrragu bullızivs & $\mathrm{JB}$ & $\mathrm{A}$ & + & + & + & + & + & + \\
\hline 32 & Agonus cataphractus $(L)$. & āḳdegunis & $\mathrm{JB}$ & $\mathrm{V}$ & & + & & 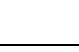 & & + \\
\hline 33 & Cyclopterus lumpus L. & zaķzivs & $\mathrm{JB}$ & A & & + & + & + & + & + \\
\hline 34 & Liparis liparis (Ekstrom) & plūkšṇzivs & JB & A & & + & + & + & + & + \\
\hline 35 & Scophthalmus maximus $(L)$. & akmenplekste & JB & $\mathrm{A}$ & + & + & + & + & + & + \\
\hline 36 & Scophthalmus rhombus (L.) & gludais rombs & $\mathrm{JB}$ & $\mathrm{V}$ & & & & & + & + \\
\hline 37 & Limanda limanda $(L)$. & limanda & $\mathrm{JB}$ & $\mathrm{V}$ & & + & + & + & + & + \\
\hline 38 & Platichtys flesus trachurus Duncker & plekste & JB & A & + & + & + & + & + & + \\
\hline 39 & Pleuronectes platessa $L$. & jūras zeltplekste & JB & $\mathrm{B}$ & & + & + & + & + & + \\
\hline \multicolumn{5}{|c|}{ Jūras zivis kopā } & 12 & 34 & 28 & 30 & 34 & 37 \\
\hline \multicolumn{11}{|c|}{ Diadromās zivis } \\
\hline 1 & Petromyzon marinus $L$. & jūras nēgis & AN & $\mathrm{C} ?$ & + & + & + & + & + & + \\
\hline 2 & Lampetra fluviatilis (L.) & upes nēǵis & AN & $\mathrm{C}$ & + & + & + & + & + & + \\
\hline 3 & Acipenser oxyrinchus Mitchill, 1815 & store & AN & EX, Re & + & + & + & + & + & + \\
\hline 4 & Alosa fallax (Lacep.) & palede & AN & $\mathrm{C} ?$ & & + & + & + & + & + \\
\hline 5 & Salmo salar $L$. & lasis & AN & $\mathrm{C}$ & + & + & + & + & + & + \\
\hline 6 & Salmo trutta $L$. & taimiņš & AN & $\mathrm{C}$ & + & + & + & + & + & + \\
\hline 7 & Coregonus lavaretus $(L)$. & sīga & AN & $\mathrm{C}$ & + & + & + & + & + & + \\
\hline 8 & Osmerus eperlanus $(L)$. & salaka & AN & $\mathrm{C}$ & + & + & + & + & + & + \\
\hline 9 & Anguilla anguilla $(L)$. & zutis & KT & & + & + & + & + & + & + \\
\hline 10 & Pelecus cultratus $(L)$. & kaze & AN & C? & + & + & + & + & + & + \\
\hline 11 & Vimba vimba $(L)$. & vimba & AN & $\mathrm{C}$ & + & + & + & + & + & + \\
\hline \multicolumn{5}{|c|}{ Diadromās zivis kopā } & 10 & 11 & 11 & 11 & 11 & 11 \\
\hline
\end{tabular}




\begin{tabular}{|c|c|c|c|c|c|c|c|c|c|c|}
\hline $\mathrm{Nr}$. & Suga & Nosaukums & Grupa & Statuss & 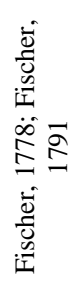 & 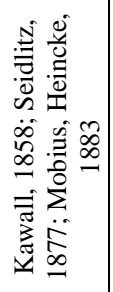 & 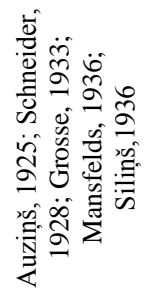 & 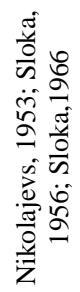 & 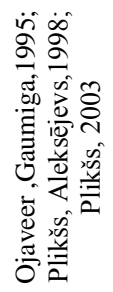 & $\frac{n}{\stackrel{n}{c}}$ \\
\hline \multicolumn{11}{|c|}{ Saldūdens zivis } \\
\hline 1 & Esox lucius $L$. & līdaka & SA & $\mathrm{V}$ & + & + & + & + & + & + \\
\hline 2 & Blicca bjoerkna $(L)$. & plicis & SA & $\mathrm{B}$ & & + & + & + & + & + \\
\hline 3 & Abramis brama $(L)$. & plaudis & SA & $\mathrm{B}$ & + & + & + & + & + & + \\
\hline 4 & Rutilus rutilus (L.) & rauda & SA & $\mathrm{B}$ & + & + & + & + & + & + \\
\hline 5 & Scardinius erythrophthalmus (L.) & rudulis & SA & $\mathrm{B}$ & + & + & + & + & + & + \\
\hline 6 & Leuciscus leuciscus (L.) & baltais sapals & SA & B & + & + & + & + & + & + \\
\hline 7 & Leuciscus idus (L.) & alants & SA & $\mathrm{B}$ & & + & + & + & + & + \\
\hline 8 & Barbus barbus (L.) & barbe & SA & $\mathrm{V}$ & & & & + & & + \\
\hline 9 & Aspius aspius (L.) & salate & SA & $\mathrm{V}$ & + & + & + & + & + & + \\
\hline 10 & Gobio gobio (L.) & grundulis & SA & $\mathrm{V}$ & + & + & + & + & + & + \\
\hline 11 & Phoxinus phoxinus (L.) & mailīte & SA & $\mathrm{V}$ & + & + & + & + & + & + \\
\hline 12 & Alburnus alburnus $(L)$. & vīḳe & SA & $\mathrm{B}$ & + & + & + & + & + & + \\
\hline 13 & Tinca tinca $(L)$. & līnis & SA & $\mathrm{V}$ & + & + & + & + & + & + \\
\hline 14 & Noemacheilus barbatulus (L.) & $\begin{array}{l}\text { bārdainais } \\
\text { akmengrauzis }\end{array}$ & SA & V? & + & + & + & + & + & \\
\hline 15 & Cobitis taenia $L$. & akmengrauzis & SA & $\mathrm{V} ?$ & + & + & + & + & + & \\
\hline 16 & Silurus glanis $L$. & sams & SA & $\mathrm{V}$ & + & + & + & + & + & + \\
\hline 17 & Lota lota $(L)$. & vēdzele & SA & $\mathrm{V}$ & + & + & + & + & + & + \\
\hline 18 & Gasterosteus aculeatus L. & $\begin{array}{l}\text { trīsadatu } \\
\text { stagars }\end{array}$ & SA & A & + & + & + & + & + & + \\
\hline 19 & Pungitius pungitius $(L)$. & $\begin{array}{l}\text { devinadatu } \\
\text { stagars }\end{array}$ & SA & $\mathrm{A}$ & + & + & + & + & + & + \\
\hline 20 & Perca fluviatilis $L$. & asaris & SA & $\mathrm{A}, \mathrm{B}$ & + & + & + & + & + & + \\
\hline 21 & Sander lucioperca (L.) & zandarts & SA & $\mathrm{B}$ & + & + & + & + & + & + \\
\hline 22 & Gymnосерhalus cernua $(L)$. & ķisis & SA & $\mathrm{B}$ & + & + & + & + & + & + \\
\hline 23 & Cottus gobio $L$. & platgalve & SA & $\mathrm{V} ?$ & & + & + & + & + & \\
\hline 24 & Carassius gibelio (Bloch) & sudrabkarūsa & SA & $\mathrm{AK}, \mathrm{B}$ & & + & & + & + & + \\
\hline 25 & Carassius carassius $(L)$. & karūsa & SA & $\mathrm{V}$ & + & + & + & + & + & + \\
\hline \multicolumn{5}{|c|}{ Saldūdens zivis kopā } & 20 & 24 & 23 & 24 & 24 & 22 \\
\hline \multicolumn{5}{|c|}{ Kopā visas zivju sugas } & 42 & 69 & 62 & 65 & 69 & 70 \\
\hline
\end{tabular}

Grupa: SA - saldūdens zivis, JP- jūras pelaǵiskās zivi, JB - jūras bentiskās zivis, AN - anadromās zivis, KT katadromās zivis,

Statuss: A - sugas vairošanās areāls ietver Latvijas ūdeņus Baltijas jūrā un Rīgas jūras līcī, AK -

aklimatizējušās sugas, B - regulārs viesis, kuru vairošanās ir saldūdeņos vai jūras kaimiņteritorijās, C anadromās zivis, kuras vairojas Latvijas saldūdeņos, C? - anadromas zivis, kuru vairošanās Latvijas saldūdeņos nav dokumentēta, EX - izzudusi suga, V- rets maldu viesis, V? - nav konstatētas pēdējos 25 gados jūras vidē, $\mathrm{Re}$ - tiek realizēta re-introdukcijas programma. 


\title{
ZOOBENTOSA SABIEDRĪBU STRUKTURĀLĀS IZMAIN̦AS UPJU MELIORATİVO DARBU VEIKŠANAS PROCESĀ
}

\author{
Arkādijs POPPELS ${ }^{1 *}$ \\ ${ }^{1}$ Rīgas Nacionālais Zoologiskais dārzs, Meža prospekts 1, Rīga, LV-1014, Latvija \\ *e-pasts: apoppels@hotmail.com
}

Pētījums tika veikts Mūsā un Salacā. Paraugi ievākti divas reizes 2013. un 2014. gadā piecās paraugošanas vietās: divas paraugošanas vietas - piekrastes zonā, divas - upes vidusdaḷā un viena augšpus upes meliorētās vietas, kur abās izpētes reizēs netika veikta upes gultnes tīrišana.

Mūsas upes zoobentosa fauna raksturojama ar augstiem vidējiem zoobentosa organismu biomasas rādītājiem: 2013. gadā - 48,2 $\mathrm{g} / \mathrm{m}^{2}$, bet 2014. $-52,78 \mathrm{~g} / \mathrm{m}^{2}$. Kā dominējošās grupas jāmin Mollusca, Trichoptera un Ephemeroptera. Zoobentosa vidējie skaitliskie rādītāji arī ir ievērojami: 2013. gadā - $5450 \mathrm{eks} / \mathrm{m}^{2}$, bet 2014. gadā $6960 \mathrm{eks} / \mathrm{m}^{2}$. Paraugos dominē tās pašas trīs grupas, tikai citā secībā: Ephemeroptera, Trichoptera un Mollusca. Paraugos tika konstatētas 53 sugas un taksoni. Pēc upju meliorēšanas darbu veikšanas paraugos tika novērota reofîlo sugu ievērojama palielināšanās. Pētījumos, kas tika veikti pēc gada, tika konstatēta upes iepriekš tīrītā posma pakāpeniska aizaugšana. Atkal vairākumā parādījās lēni tekošiem ūdeniiem raksturīgas sugas.

Salacas upes zoobentosa biomasas vidējie rādītāji ir augsti: 2013. gadā $-49,0 \mathrm{~g} / \mathrm{m}^{2}$, un te dominē Mollusca - 82,8 \% no kopējās zoobentosa biomasas, bet 2014. gadā - 28,87g/m², kur dominē Trichoptera $\left(14,2 \mathrm{~g} / \mathrm{m}^{2}\right)$, tai seko Mollusca $-5,19 \mathrm{~g} / \mathrm{m}^{2}$. Jāatzīmē, ka arī zoobentosa organismu indivīdu skaits (eks/m²) ir augsts, kas 2013. gadā raksturojams ar vidējiem rādīiājiem - 1662 eks $/ \mathrm{m}^{2}$, bet 2014. gadā $8225 \mathrm{eks} / \mathrm{m}^{2}$. Abos pētījumu gados dominē grupa Varia (atbilstoši - $7625 \mathrm{eks} / \mathrm{m}^{2}$ un $2175 \mathrm{eks} / \mathrm{m}^{2}$ ). Paraugos tika konstatētas 56 zoobentosa organismu sugas un taksoni. Veicot meliorācijas tīrī̌sanas darbus, arī te novēroja atsevišķ sugu skaita un biomasas uzplaukumu, kā arī lēni tekošu ūdeņu mīlošu sugu nomaiṇu pret reofîlām sugām. Kopumā abu pētìto upju reofîlajos posmos ievērojamā daudzumā konstatētas Hydropsyche angustipennis, Baetis niger, Heptagenia sulphurea, Theodoxus fluviatilis un Sphaerium corneum. Upju aizaugušie posmi raksturīgi ar tādām sugām kā Radix ovata, Bithynia tentaculata, Caenis sp. 
Veicot upes attīrī̌sanu no ūdensaugiem, novērojama zoobentosa organismu sugu nomaiņa: parādās straumi mīlošas - reofîlās sugas, kas nomaina lēni tekošiem ūdeṇiem raksturīgās sugas. Lai saglabātu ritrālam raksturīgo biocenozi, nepieciešama regulāra attīīîto vietu rekultivēšana, kas saglabās iztīintā upes posma ekoloǵisko stāvokli, jo pretējā gadījumā tas atkal aizaugs. Attīinitajā upes posmā būs optimāli apstākḷi baroties un nērst ikrus lašveidīgām zivīm. 


\title{
GLIEMEN̦U MYTULUS TROSSULUS AUDZĒŠANAS IESPĒJAS LATVIJAS PIEKRASTĒ
}

\author{
Ingrīda PURIN̦A*, Ieva BĀRDA \\ ${ }^{1}$ Latvijas Hidroekologijas Institūts, Eksperimentālās Hidrobiologíijas nodaḷa \\ *e-pasts: ingrida.purina@lhei.lv
}

Eitrofikācija šobrīd ir viena no būtiskākajām problēmām Baltijas jūrā. Baltijas Jūras Rīcības plāns paredz, ka Latvijai ir jāsamazina slāpekḷa ieplūdes jūrā par 2560 t un fosfors par 300 t līdz 2021. gadam. To iespējams izdarīt uzlabojot lauksaimniecības zemju apstrādi upju sateces baseinos, samazinot minerālmēslu lietošanas apjomus, veidojot biolog̣iskās lauksaimniecības, atjaunojot mitrājus, atjaunojot aizsargjoslas ūdenstilpju krastos, būvējot labākas notekūdeṇu attīrǐšanas iekārtas pilsētās un ciemos. Taču papildus šīm nepieciešamajām darbībām ir iespējama arī ekoloǵisko gliemeṇu fermu uzstādīšana Baltijas jūrā.

Lai izpētītu gliemeṇu audzēšanas potenciālu Baltijas jūras piekrastē, tika uzsākts pētījums par gliemeṇu kāpuru piestiprināšanos pie mākslīgā substrāta. 2013. gada maija sākumā Baltijas jūrā pie Jūrmalciema, Liepājas un Pāvilostas $15 \mathrm{~m}, 20 \mathrm{~m}$ un $25 \mathrm{~m}$ dziḷumos tika noenkurotas vertikālas virves ar boju ūdens virspusē. Katru mēnesi pētījuma vietas tika apsekotas, ievācot gliemeṇu peldošo stadiju paraugus, fitoplanktona paraugus, mērot barības vielu koncentrācijas ūden̄̄.

Pētījumā tika konstatēts, ka gliemeṇu nārsta kulminācija Latvijas piekrastē notiek maija vidū, kad gliemeṇu kāpuru skaits sasniedz 11 tūkstošus litrā. Apsekojot pētījuma vietas septembrī, visās 9 vietās tika konstatēta gliemeṇu kāpuru piestiprināšanās virvēm. Lielākais piestiprinājušos gliemeņu skaits tika konstatēts 6-10m dziḷumā, bet mazākais - 2m dziḷumā, ko nosaka intensīvā vēja un viḷnu iedarbība Latvijas piekrastē. Lielāks gliemeṇu skaits konstatēts uz virvēm, kas atrodas tālāk no krasta - 20m un 25m dziḷumā. Lielākās gliemenes ( 3mm) tika atrastas Pāvilostā, kas liecina, ka Pāvilostā tās nārstojušas agrāk un to augšanas apstākḷi bijuši labvēlīgāki. Liepājā un Jūrmalciemā gliemenes sasniedza aptuveni $2 \mathrm{~mm}$ garumu. Metamorfozes laikā gliemeṇu kāpura izmērs ir $0.3 \mathrm{~mm}$, kas 2 mēnešu laikā pieaug 10 reizes. Apsekojot gliemenes pēc gada jūrā redzama krasa diferenciācija starp stacijām un dziḷumiem. Gliemenēm visnelabvēlīgākie apstākḷi konstatēti Jūrmalciemā, kur augšanas apstākḷus būtiski ietekmē piesārṇojuma un barības vielu ieplūdes no Kuršu jomas, bet vislabākie apstākḷi gliemeṇu audzēšanai ir Pāvilostā. Tas liecina, ka gliemeṇu fermai labvēlīgākas vietas ir tālāk no lieliem piesārṇojuma avotiem un dziḷāk jūrā, kur hidrodinamiskie spēki ir mazāki. Interpolējot eksperimentālos 
rezultātus, var aprēḳināt, ka Kurzemes piekrastē iegūstamā gliemeṇu biomasa ir no 4.1 t/ha Jūrmalciemā līdz 28.5 t/ha Pāvilostā, liecinot par būtisku gliemeṇu audzēšanas potenciālu Baltijas jūras atklātajā piekrastē.

Projekts tika izstrādāts Centrālās Baltijas Pārrobežu programmā IVA „Baltic EcoMussel”(2012-2013) ietvaros. 


\title{
STORES SASTOPAMĪBAS UN REINTRODUKCIJAS VĒSTURE LATVIJĀ
}

\author{
Santa PURVIN̦A, Ruta MEDNE, Mārcis ZIN̦G̣IS \\ Pārtikas drošības, dzīvnieku veselības un vides zinātniskais institūts BIOR \\ *e-pasts: santa.purvina@bior.lv
}

Latvijā store ir bijusi labi pazīstama zivs kopš sirmas senatnes. Rakstos termins „stuõre” (stuore) ir lietots jau 17. gs. pirmajās latviešu-vācu un vācu-latviešu leksikona vārdnīcās, ko sastādījušsi tā laika progresīvie mācītāji Jānis Langijs un Gothards Frīdrihs Stenders, tas minēts arī Jura Plāķa pêtījumā „Kursenieku valoda” un Kārḷa Mīlenbaha un Jāṇa Endzelīna „Latviešu valodas vārdnīca”. Ihtioloğiskajā literatūrā pirmoreiz šo vārdu ir ieviesis A. Dīriḳis Rīgas Latviešu biedrības 1893. gadā izdotajā Zinību komisijas rakstu krājumā „Baltijas kaulu kustoṇi” (Blaumane, 1973).

Senatnē stores ir bijušas nozīmīgs zvejas objekts Latvijā, par ko liecina zivju atliekas, kas atrastas visās senajās apmetnēs Daugavas lejteces krastos, kuru izpētē un zivju kaulu atpazīšanā ir piedalījies LZA Biologijas institūta ihtiologs Jānis Sloka. Senākās liecības par storu zvejošanu Daugavā ir atrastas bronzas laikmeta apmetnē Ķivutkalnā (Doles salas vidusdaḷa), kas datējamas ar laiku pirms 3000 gadiem. Šajā laikā Daugavas piekrastes iemītnieki medīja stores, kas nārsta laikā koncentrējās upju seklākajās vietās, un samērā viegli ieguva lielus lomus. Interesanti, ka šeit storu kauli ir atrasti visos izrakumu slāṇos, kas liecina, ka senajā Daugavā stores ir bijušas bieži sastopamas un intensīvi zvejotas visā apmetnes pastāvēšanas laikā. Noteikts, ka noķerto storu garums ir bijis no 192 cm līdz $360 \mathrm{~cm}$, vidēji $251 \mathrm{~cm}$, un maksimālais svars $300 \mathrm{~kg}$. Fakts, ka Ķivutkalnā atrastas gandrīz tikai liela izmēra zivis, liek domāt, ka bronzas laikmetā zvejas tehnika bijusi attiecīgi orientēta, stores un līdakas medītas ar šḳēpiem un bultām, bet pārējāas lielās sugas ar lieliem āḳiem (Sloka 1970).

Otra plaša storu kaulu atradumu grupa nāk no pētītajām 10.-13. gs. apdzīvotajām vietām Daugavas krastos: Jersikas, Asotes un Aizkraukles pilskalniem, Kabeḷu, Lipšu Raušu apmetnēm, Daugmales pilskalna un senpilsētas, Mārtiņsalas pils un ciema vietas, kā arī no Rīgas. Visās šajā vietās starp citiem zivju kauliem atrastas arī storu paliekas. Salīdzinājumā ar kopējo zivju skaitu, storu ir bijis 2-95\% (Caune, 1992). 
Storu kauli nav identificēti Mežotnes pilskalna apmetnē, kas atrodas pie Lielupes, kā arī nav atrasti iekšzemes apmetnēs, kas atradās pie Latvijas ezeriem, piem., Vecates apmetnē pie Burtnieku ezera Zvidzes apmetnē Madonas rajonā, Tērvetes pilskalnā (Sloka, 1985, Sloka, 1986 (I un II)).

12. un 13 gs. Rietumeiropā stores bija viena no visvairāk pieminētajām zivs sugām tā laika rakstu liecībās, kā arī tā bija viena no vērtīgākajām dāvanām, ko starpvalstu sūtṇi pasniedza dāvanās oficiālu viz̄̄šu laikā (Ludwig, Gessner, 2007). Par to, ka arī rīdzinieki 13. - 14. gadsimtā pusdienās ir ēduši stores, liecina materiāli, kas savākti arheoloǵiskajos izrakumos Rīgā, ko vadījis arheologs A. Caune, laikā no 1971. - 1976. gadam. Storu vairodziṇi un dažkārt arī spuru stari ir atrasti izrakumos Ministerejas ielā, Peitavas ielā, Trokšṇu ielā, Peldu un Ūdensvada ielas stūrī. Arheologiskie pētījumi liecina, ka 13. - 14. gadsimtā store bija viena no nozīmīgākajām sugām (Sloka, 1977). Turpretī jau 17. gs Rīgas rāte nosaka, ka zivju nodevās 2 stores atsver 3 lašus, kas liecina, ka storu Daugavā ir palicis mazāk, kā lašu. Par storu rūpniecisko zveju 19. gs Daugavā vairs nav nekādu ziņu. Tikai divdesmitā gadsimta 20. gadu sākumā kā sensācija presē aprakstīts notikums par kādu zvejnieku, kas Daugavas grīvā pavasarī noķēris ap $2 \mathrm{~m}$ garu stori un izdevīgi to pārdevis Rīgas labākajam restorānam (Caune, 1992).

Storu skaita kritumu uzrāda lomu statistika 19. gs. beigās visās lielo upju sistēmās, kuras apdzīvojusi store (Ludwig, Gessner, 2007). Par storu kādreizējo daudzumu un straujo izzušanu pēdējo simt gadu laikā liecina arī šādi vācu ihtiologa E. Mora savāktie statistiskas dati: Holandē 1893. gadā bijušas noḳertas 832 stores, bet 1918. gadā vairs tikai 16 zivis; Elbā pie Hamburgas 1891. gadā bijis rekordloms - 3650 stores, bet 1918. gadā vairs tikai 34 stores; Emsas grīvā 1891. gadā nozvejotas 197, bet 1916. gadā vairs tikai 7 stores (Caune, 1992).

Storu skaita samazinājumam 19. gs beigās ir vairāki iemesli. Viens no svarīgākajiem ir nesaudz̄̄̄ā zveja nārsta laikā. Tomēr papildus zvejai, ir vēl viens ḷoti nopietns antropogēnais faktors, kas varēja ietekmēt Baltijas stores populāciju. Kopš otrās tūkstošgades sākuma Eiropā ir pakāpeniski tikuši izcirsti meži, kas novedis pie palielināta sedimentu transporta un izmain̄ām lielo upju deltu rajonos un storu nārsta vietās (Hoffmann, 1996). Šis antropogēnais faktors kḷuva arvien intensīvāks viduslaikos, kad pieauga atkritumu daudzums no lielajām pilsētām. Rietumeiropā upju piesārṇojums sasniedza maksimumu industriālās revolūcijas laikā 18. - 20. gs. Arī Rīgā šai laikā notika strauja rūpniecības izaugsme, kad attīstījās metālapstrāde, mašīnbūve, ķīmiskā rūpniecība, š̌kiedru apstrāde, 
vadmalas, ķemmdzijas audumu ražošana, papīra, porcelāna, fajansa, korḳu ražošana, kokzāgeēšana, u.c. Rīgas kanalizācijas sistēma sākotnēji tika veidota kā saimniecisko un lietusūdeṇu vienota novadīšanas sistēma, un visi notekūdeņi tika novadīti Rīgas pilsētas robežās esošajās vai tai pieguḷošajās ūdenskrātuvēs. G. Bonne 1905. gadā ir konstatējis, ka Elbas upē Hamburga un Altona (Vācija) komunālos notekūdeņus sāka ielaist no 1862. gada, tieši vienā no nozīmīgākajām KoehlBrandt nārsta vietām, kas izraisīja periodisku skābekḷa trūkumu upē gada siltajās sezonās (Ludwig, Gessner, 2007).

Atlantijas store, Acipenser oxyrinchus, kas kādreiz mitusi Baltijas jūrā, vairojas gada siltajā sezonā, kad ūdens temperatūra ir apmēram $20^{\circ} \mathrm{C}$. Tas ir laiks, kad dabā ir visstraujākie metabolisma procesi, kad ikri ir visjūtīgākie pret skābekḷa deficītu un cieš no antropogēnās darbības izraisītā mikrobiālā piesārņojuma. Iespējams, ka tāpēc store bija pirmā zivs, kas visjūtīgāk reaǵēja uz izmaiṇām ūdens sistēmās. Dzīvotṇu pārveidošana un piesārņošana kopā ar spēcīgu zvejniecību uz jaunajiem un pieaugušajiem īpatniem bija svarīgākie stores izmiršanas iemesli Baltijas jūrā (Ludwig, Gessner, 2007).

Pagājušā gadsimta vidū uzskatīja, ka atjaunot Acipenser oxyrinchus resursus Latvijā ir neiespējami, jo neuzskatīja par nepieciešamu ievest sugas no Rietumiem, tāpēc Daugavā tika sākts aklimatizēt sugas, kas ir sastopamas Padomju Savien̄̄bā. Sterlete (Acipenser ruthenus L.) ir viena no ātraudzīgākajām sugām. Tās aklimatizācija tika sākta jau 1948. gadā, kad Daugavā tika izlaisti līdz 4-5 gadu vecas zivis, kopā 3316 gb. Vēlākos gados sterlete periodiski tika noḳerta Daugavā un visā Rīgas līča piekrastē. Uzskata, ka Latvijā notika arī izlaistās sterletes nārsts, jo laikā no 1950. līdz 1953. gadam tika noḳertas trīs $12-15 \mathrm{~cm}$ garas sterletes. Tā kā tika izlaistas lielas zivis, secināja, ka ir noticis sterletes nārsts un aklimatizācija ir iespējama, bet tai jānotiek lielākos mērogos (БалтНИРХ, 1961). Laikā no 1962. līdz 1966. gadam Daugavas un Gaujas lejtecē tika izlaisti sekojošu storu sugu mazuli: 16 tūkst. Krievijas stores (Acipenser gueldenstaedtii Brandt), 8,2 tūkst. Baikāla stores (Acipenser baerii baicalensis) un 0,9 tūkst Sibīrijas stores (Acipenser baerii). Izlaistās zivis izplatījās Rīgas līcī, kā arī aiz tā robežām. Noķertām zivīm tika konstatēts augsts augšanas ātrums, kas liecināja, ka tās nejuta barības bāzes trūkumu, tomēr tā kā vēlākos gados mazas zivis netika noḳertas, var uzskatīt, ka izlaidumi nebija tik sekmīgi, lai notiktu to nārsts (БалтНИРХ, 1969).

Pēdējās desmitgadēs Eiropas pilsētas mērḳtiecīgi uzlabo notekūdeṇu attīrīšanu, arī Rīgas komunālo notekūdeṇu attīrǐšanas iekārtas „Daugavgrīva” darbojas kops 1991. gada, kā rezultātā ir uzlabojies ekoloǵiskais stāvoklis gan Rīgas līcī, gan Baltijas jūrā. Šodien Eiropas valstis ir sākušas 
Acipenser oxyrinchus populācijas atjaunošanu jūrā. Darbam ir pievienojusies arī Latvijas ZI BIOR, kas pēdējo divu gadu laikā Daugavas grīvā ir izlaidusi 3,5 tūkst. stores mazuḷu, par izlaišanas sekmēm varēsim spriest nākamajos gados.

\section{Izmantotā literatūra:}

Blaumane, B. 1973. Zivju nosaukumi Latviešu valodā. Rīga, Zinātne, 304.

Caune, A. 1992. ... pati R̄̄ga Ūdenī. Rīga, Zinātne, 168 lpp.

Hoffmann, R. C. 1996. Economic development and aquatic ecosystems in medieval Europe. American History Reviews, 101:631-669.

Ludwig, A., Gessner, A. 2007. What makes the diference? - Sea sturgeon on both sides of the Atlantic ocean. American Society Symposium. In Anadromous sturgeons: habitats, threats, and management. Edited by Munro J, Hatin D, Hightower JE, McKwon K, Sulak KJ, Kahnle AW, Caron F., 56:285-300.

Sloka, J. 1977. Rīgas XIII-XIV gs.kultūrslān̄̄ atrastās zivis. Latvijas PSR Zinātņu Akadēmijas Vēstis, 6:100-107.

Sloka, J. 1985. Akmens laikmetā zvejotās zivis Zvejnieku II apmetnē (8.-6. g.t. p.m.ē.). Latvijas PSR Zinātṇu Akadēmijas Vēstis, 7:110-116.

Sloka, J. 1986 (I). Zivis Tērvetes pilskalnā (X-XIII gs.) un Mežotnes pilskalnā (XI-XII gs.). Latvijas PSR Zinātṇu Akadēmijas Vēstis, 9:131-135.

Sloka, J. 1986 (II). Zivis Zvidzes mezolīta un neolīta apmetnē (VI-III g.t. p.m.ē). Latvijas PSR Zinātņu Akadēmijas Vēstis, 9:127-130.

БалтНИРХ 1961. Отчет о работе за 1961 год по теме Аклиматизация новых пород рыб и позвоночных в Рижском заливе. Рига, 1-16.

БалтНИРХ 1969. Отчет о работе за 1969 год по теме Изучение возможности увелечения рыбных запасов водоемов Балтики в условиях зарегулированного стока рек. Рига, 137. 


\title{
SEŠU DAŽĀDU JONU ŠḲĪDUMU EKOTOKSICITĀTE, IZMANTOJOT DAPHNIA MAGNA, VIBRIO FISCHERI UN DANIO RERIO EKOTOKSICITĀTES TESTU
}

\author{
Ieva PUTNA ${ }^{1,2 *}$ \\ ${ }^{1}$ Latvijas Hidroekologijas institūts, Daugavgrīvas 8, Rìga \\ ${ }^{2}$ Latvijas Universitātes Bioloğijas fakultātes Hidrobiologijas katedra, Kronvalda bulvāris 4, Rīga \\ *e-pasts: ieva.putna@lhei.lv
}

Lielākā daḷa gaistošo organisko savienojumu, kas šobrīd tiek izmantoti industrijā, ir toksiski gan cilvēkiem, kas iesaistīti to ražošanā, gan patērētājiem. Tie ir gaistoši, kait̄̄gi videi un viegli uzliesmojoši, kas savukārt padara tos par sprādzienbīstamiem. Daudzi gaistošie organiskie šḳīdinātāji jau ir aizliegti pamatojotie uz informāciju par to kaitīgumu un emisiju atmosfērā un ūdeņos. Daudzi zinātnieki ir fokusējušies uz iespējamo alternatīvu meklējumiem, kas aizstātu esošos savienojumus (Thuy Pham et al., 2010). Salīdzinot dažādas alternatīvas, liela zinātnieku uzmanība tikusi pievērsta jonu škīdumiem (Blanchard et al., 1999; Blanchard, Brennecke, 2001; Willauer et al., 1999).

Jonu šķīdumi ir organsiki nearomātskie sāl̨i ar zemu kušanas temperatūru, un tie tiek uzskatīti par iespējamiem gaistošo organisko savienojumu aizvietotājiem. Uzskats, ka tie ir "videi draudzīgāki", galvenokārt tiek balstîts uz to, ka tiem ir augsta ķīmiskā stabilitāte un šķīīiba ūdenī, niecīgs tvaika spiediens un tie nav degoši. Šīs īpašības piesasita industrijas uzmanību, tomēr šīs pašas īpašības rada bažas par to degradāciju un vai noturību vidē, turklāt to augstā škīīỉbas spēja ūdenī liecina par to, ka tā būs vide, caur kuru jonu šḳīdumi nonāks vidē (Anthony et al., 2001; McFarlane et al., 2005; Wong et al., 2002). Kopumā, šobrīd informācija par konkrētu jonu šķīdumu ietekmi uz vidi ir diezgan maz, kas ir barjera to izmantošanai industriāliem mērkiiem (Thuy Pham et al., 2010).

Pētîjuma mērḳis bija noteikt 6 dažādu jonu šḳīdumu (C1, C2, C4, C7, C9, C10) ekotoksicitāti, izmantojot Vibrio fischeri bioluminescences inhibīcijas testu (Microtox ISO 11348), Daphnia magna akūto (ISO 6341) un hronisko testu (EN ISO 10706) un zivju Danio rerio embrioǵenēzes limita testu (modificēts OECD 236).

Testu rezultâti liecināja pa jonu šḳīdumu atšķīīịu ekotoksiskumu. V. fischeri testā ausgtāko toksikumu uzrādīja jonu šķīdumi C9 un C10 - LC 50 vērtības gan pēc 15, gan 30 min ekspozīcijas bija 


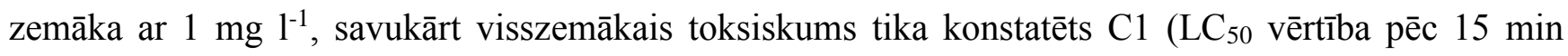
14.35 un $30 \mathrm{~min}-12.69 \mathrm{mg} \mathrm{l}^{-1}$ ). Pēc $V$. fischeri testa rezultātiem jonu šḳīdumi pēc to toksicitātes veido sakarību $\mathrm{C} 1<\mathrm{C} 2<\mathrm{C} 4<\mathrm{C} 7<\mathrm{C} 9<\mathrm{C} 10$. Akūtais D.magna tests uzrādīja augstāku jutību pret jonu šḳ̄īumu

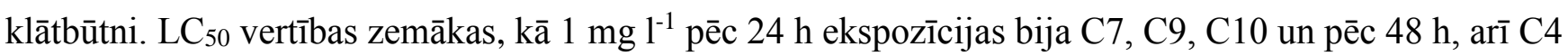
klātbūtnē. Arī šai testā C1 tika konstatēts viszemākais toksiskums (LC ${ }_{50}$ vērtība pēc 24 h 10.64 un 48 h - $6.31 \mathrm{mg} \mathrm{l}^{-1}$ ). Pēc D.magna akūtā testa rezultātiem jonu šḳīdumi pēc to toksicitātes veido sakarību $\mathrm{C} 1<\mathrm{C} 2<\mathrm{C} 4<\mathrm{C} 7<\mathrm{C} 10<\mathrm{C} 9$. D.magna hroniskais tests tika veikts tikai 3 jonu šķ̄idumiem - C1, C2 un C9 limitētu materiālu un laika dēḷ. Testos tika konstatēts, ka D.magna mirstība pieaug, palielinoties ekspozīcijas laikam, kā arī tas, ka noteiktas subletālas jonu šḳ̄̄umu koncentrācijas stimulē D.magna reprodukciju. D.rerio embrioǵenēs limita tests tika veikts ar divām koncentrācijām - 10 un $100 \mathrm{mg} \mathrm{l}^{-1}$. Testos ar jonu šķīdumu koncentrāciju 100 mg 1 1, tika konstatēts, ka jonu šķīdumi C1, C2 un C7 nav toksiski zivīm (OECD 203), savukārt C9 un C10 klātbūtnē tika novērota 100\%-īga ikru koagulācija jau

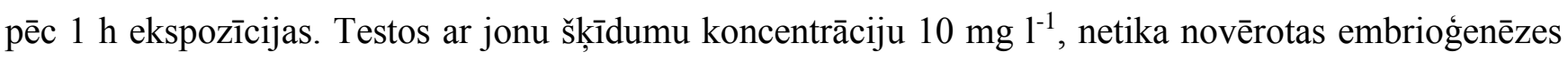
izmaiṇas, salīdzinot ar kontroli. Lai gan būtu nepieciešami papildus pētījumi par specifisku jonu šķ̄īdumu iedarbību uz dažādiem testorganismiem, kopumā, pētîjums pierāda jonu šķīdumu spēju būt augsti toksiskiem, tādējādi apšaubot apgalvojumu par to, ka tie ir "videi draudzīgi".

Petījums ticis izstrādāts ERASMUS studiju ietvaros.

Izsaku pateicību Masaryk Universitātes Zinātņu fakultātes izpētes centram RECETOX (Toksisko Research Centre for Toxic Compounds in the Environment).

\section{Izmantotā literatūra:}

Anthony, J.L., Maginn, E.J., Brennecke, J.F., 2001. Solution thermodynamics of imidazolium-based ionic liquids and water. J. Phys. Chem. B 105, 10942-10949.

Blanchard, L.A., Hancu, D., Beckman, E.J., Brennecke, J.F., 1999. Green processing using ionic liquids andCO2. Nature 399, 28-29.

Blanchard, L.A., Brennecke, J.F., 2001. Recovery of organic products from ionic liquids using supercritical carbon dioxide. Ind. Eng. Chem. Res. 40, 287-292. 
ISO 11348 Water quality -- Determination of the inhibitory effect of water samples on the light emission of Vibrio fischeri (Luminescent bacteria test)

ISO 10706 Water quality -- Determination of long term toxicity of substances to Daphnia magna Straus (Cladocera, Crustacea).

ISO 6341 Water quality -- Determination of the inhibition of the mobility of Daphnia magna Straus (Cladocera, Crustacea) -- Acute toxicity test

McFarlane, J., Ridenour, W.B., Luo, H., Hunt, R.D., Depaoli, D.W., Ren, R.X., 2005. Room temperature ionic liquids for separating organics from produced water. Sep. Sci. Technol 40, 1245-1265.

Thuy Pham Thi Phuong, Cho Chul-Woong, Yun Yeoung-Sang. 2010. Environmental fate and toxicity of ionic liquids: A review. water research Vol. 44: 352 - 372 pp).

OECD 236 Fish Embryo Acute Toxicity (FET) Test. OECD Guidelines for the Testing of Chemicals, Section 2. Effects on Biotic Systems; ISSN : 2074-5761 (online); DOI : 10.1787/20745761

OECD 203 Fish, Acute Toxicity Test. OECD Guidelines for the Testing of Chemicals, Section 2 Effects on Biotic Systems; ISSN: 2074-5761 (online); DOI: 10.1787/20745761

Willauer, H.D., Huddleston, J.G., Griffin, S.T., Rogers, R.D., 1999. Partitioning of aromatic molecules in aqueous biphasic systems. Sep. Sci. Technol 34, 1069-1090.

Wong, D.S.H., Chen, J.P., Chang, J.M., Chou, C.H., 2002. Phase equilibria of water and ionic liquids [emim][PF6] and [bmim][PF6]. Fluid Phase Equilibr 194-197, 1089-1095. 


\section{ZOOPLANKTONA UN REŅĢES CLUPEA HARENGUS L. TELPISKAIS SADALĪJUMS UN SAVSTARPĒJĀ IETEKME RĪGAS LĪC̄̄ $\quad$ (BALTIJAS JŪRĀ) \\ Gunta RUBENE ${ }^{1 *}$, Ivars PUTNIS ${ }^{1}$, Guntars STRODS ${ }^{1}$}

${ }^{1}$ Pārtikas drošības, vides veselības un vides zinatniskais institūts „BIOR”, Zivju resursu petniecības departaments, Jūras nodaḷa. Daugavgrīvas 8, Rīga, LV-1048.

*e-pasts: Gunta.Rubene@bior.gov.lv

Rīgas līcis ir relatīvi sekls un dạ̦ēji norobežots iesāḷūdens baseins Baltijas jūrā, kuru raksturo jutīgs hidroloǵiskais režīms. Regulāra saldūdens ieplūde no lielajām upēm un sāḷūdens apmaiņa caur Irbes jūras šaurumu nosaka līča horizontālo un vertikālo sāļuma gradientu (Берзиньш, 1987). Saistībā ar sāļuma horizontālajām izmaiņām, līcī sastopamas zooplanktona sugas ar saldūdens vai jūras izcelsmi. Mainoties abiotiskajiem vides apstākḷiem, atsevišķu sugu spēja izdzīvot, augt un attīstīties ir ierobežota, tāpēc līcī sastopamo sugu daudzveidība ir zema, kas nosaka arī salīdzinoši nelielo trofiskās ķēdes elementu skaitu. Atšķirībā no Baltijas jūras centrālās daḷas, kur dominējošā suga ir brētliṇa (Sprattus sprattus balticus), Rīgas līcī brētliṇas daudzums ir salīdzinoši neliels un no planktonēdājām zivīm dominējošā suga ir reṇge (Clupea harengus membras L.). Reṇges krājuma lielums 90-to gadu sākumā līcī strauji palielinājās, vienlaikus strauji samazinoties zivju vidējai masai vecuma grupās (ICES, 2014a), kas netieši liecina, ka lejupejošās kontroles veidā reņǵes ietekme uz zooplanktona daudzumu varētu būt palielinājusies. Zooplanktona sekundārā produkcija (P) ir svarīgs trofiskko apstākḷu funkcionālais rādītājs jūras ekosistēmās (ICES, 2014b). Temperatūra, sugu-specifiskais augšanas ātrums un barības apstākḷi ir daži no faktoriem, kas spēj ietekmēt zooplanktona produkciju. Turpretī barības patēriņš (Q) ir nozīmīgs planktonēdāju zivju barošanās ietekmes rādītājs. Reṇǵes barošanās pētījumu rezultāti parasti tiek analizēti sezonālā un daudzgadīgā skatījumā un bieži vien attiecināti vidēji uz visu līci (Lankov et al., 2010; Raid et al., 2010). Tomēr zooplanktona un planktonēdāju zivju izplatības un trofiskās mỉjiedarbības sasaiste telpiski Rīgas līcī aprakstīta maz. Tāpēc š̀̃ pētījuma mērḳis ir noskaidrot, kāda ir reṇges izēšanas ietekmes un zooplanktona produkcijas heterogenitāte līcī un kādi ir iespējamie faktori, kas nosaka šo procesu telpiskās atškirības.

Pētîjumā izmantoti dati, kas iegūti Rīgas līča hidroakustiskās uzskaites reisā 2011. gadā (25. jūlijs - 3. augusts). Kopš 1999. gada hidroakustiskās zivju uzskaites Rīgas līcī tiek veiktas vasarā 
(jūlijs/augusts) apvienotajos Latvijas-Igaunijas reisos, kas ḷauj iegūt informāciju par visu līča akvatoriju. Zivju biologiiskie paraugi ievākti vietās, kur hidroakustiski novērotas lielākas zivju koncentrācijas. Katrā bioloǵiskajā paraugā noteikts reṇǵu masas, garuma un vecuma sadalījums. Biomasas aprēḳināšanai izmantoti hidroakustiskās uzskaites stacijās aprēḳinātie reṇges kopējā skaita dati (uz laukuma vienību) un individuālā svara dati bioloǵiskajā analīzē, pēc kā aprēḳināta reṇǵes kopējā biomasa (uz laukuma vienību) katrā stacijā. Barošanās raksturošanai izmantoti reisa laikā ievāktie rengǵes barošanās dati, kuru apstrāde veikta projekta LIMOD (2012) ietvaros. Zivis sadalītas izmēru grupās - <10 cm, 10-11.9 cm, 12-13.9 cm, 14-15.9 cm, 16-17.9 cm un katrai grupai aprēķināts barības objektu sastāvs. Tā kā barošanās paraugs bija ievākts vienā stacijā (1. attēls), iegūtā informācija par barības sastāvu tika reprezentatīvi attiecināta uz visām pārējām stacijām, ņemot vērā reņǵes izmēra sadalījumu katrā no stacijām un aprēķinot kopējo barības sastāvu (vidējais svērtais), visa rengǵes krājuma barošanās raksturošanai katrā no stacijām. Lai precīzi izvērtētu rengǵes barošanās ietekmi uz zooplanktonu, tika aprēḳināts kopējais zooplanktona daudzums, ko reṇge izēd katrā stacijā (dienā), kas pēc tam, balstoties uz aprēķināto barības sastāvu katrā no stacijām, tika attiecināts uz atsevišḳām zooplanktona sugām. Reṇges dienas barības patēriṇa (Q) aprēḳinam tika izmantoti projektā LIMOD (2012) izstrādātie Q/B koeficienti (rengges bioenerǵētiskais modelis), kas sezonāli raksturo dienas barības patēriṇu reṇggei ar dažādu individuālo masu, un reṇǵes masas sadalījums (svērtais vidējais) katrā no stacijām. Iegūtais koeficients tika attiecināts uz kopējo aprēḳināto reṇǵes biomasu (uz laukuma vienību) katrā no stacijām.

Zooplanktona paraugi ievākti vienlaicīgi ar zivju tralējumiem, izmantojot Džedi tipa planktona tīklu ar 160 mikronu acu izmēru (augšējās sekcijas diametrs $37 \mathrm{~cm}$, videjās sekcijas diametrs $50 \mathrm{~cm}$ ). Kopumā zooplanktona paraugi ievākti 13 stacijās (1.attēls). Paraugi analizēti laboratorijā, nosakot sugu sastāvu un indivīdu skaitu katrā paraugā. Biomasas aprēḳini veikti, izmantojot sugu individuālās masas faktorus (Henroth, 1985). Šajā pētījumā izmantoti dati par piecām svarīgākajām reṇğu barošanās mērķsugām - airkājvēžiem (Copepoda) Acartia spp., Eurytemora affinis un Limnocalanus macrurus, kā arī lapkājvēžiem (Cladocera) Bosmina coregoni un Cercopagis pengoi. 


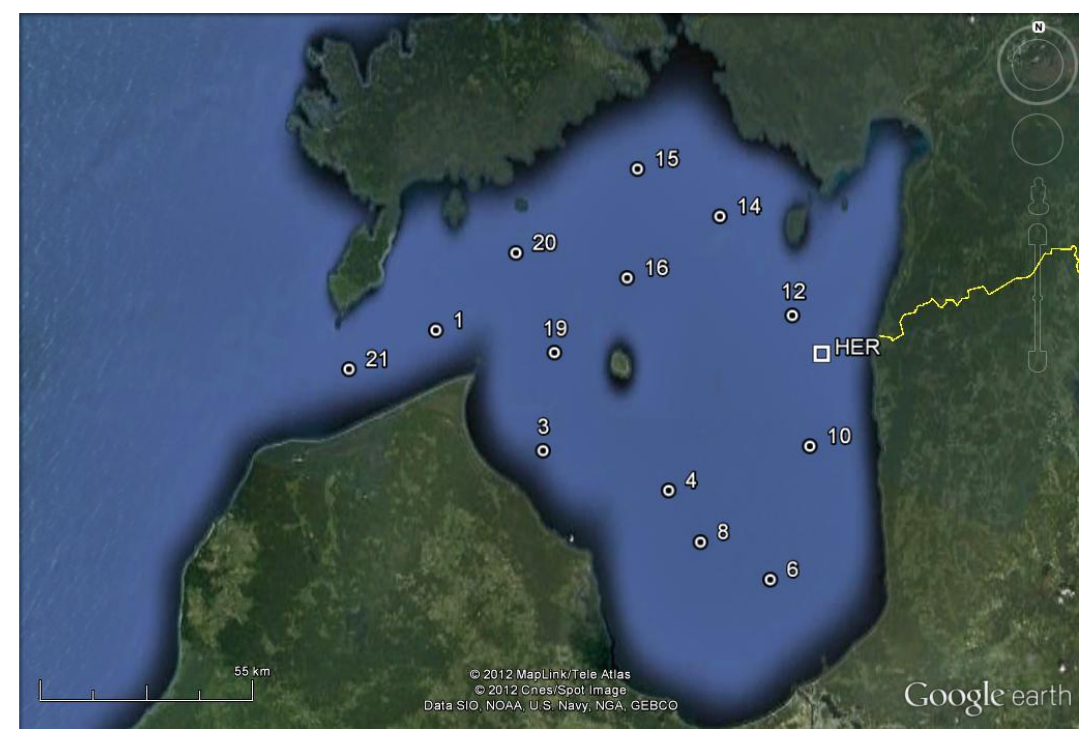

1.attēls. Zooplanktona un reņges paraugu ievākšanas stacijas Rīgas līcī 2011.gada jūlijā. HER ievākts ren,ǵes barošanās paraugs, stacijas apzīmē hidroakustiskās uzskaites tralējuma kārtas numuru.

Airkajvēžu sugu populāciju produkcija (P) noteikta, izmantojot visparīgu formulu zooplanktona produkcijas aprēķināšanai (Peterson et al., 1991):

$\mathrm{P}=\mathrm{gB}$, kur $\mathrm{P}$ - produkcija, $\mathrm{g}$ - populācijas augšanas ātrums, bet $\mathrm{B}$ - biomasa.

Airkājvēžu populācijas augšanas ātrums g aprēķināts, izmantojot eksponenciālu formulu, kurā kā noteicošais faktors ir temperatūra (Huntley, Lopez, 1995):

$\mathrm{g}=0,0445 \mathrm{e}^{0,111 \mathrm{~T}}$

Šīs formulas pamatā ir pieņēmums, ka airkājvēžu augšana ir eksponenciāla, neatkarīga no organismu individuālās masas un barības apstākḷiem. Huntley un Lopez (1995) pētījumā pierādīts, ka $91 \%$ no airkājvēžu augšanas ātruma izmaiṇām var raksturot, izmantojot tikai ūdens temperatūru. Savukārt Hirst and Sheader (1997) novērojuši, ka š̄ sakarība var tikt attiecināta uz mazajiem airkājvēžiem, taču var neprecīzi atspoguḷot lielāko sugu augšanu. N̦emot vērā, ka airkājvēža L.macrurus dzīves cikls ir monociklisks un tas pieskaitāms pie lielāka izmēra zooplanktona sugām, šīs 
sugas augšanas ātruma noteikšanai izmantota cita sakarība, kuras pamatā ir populācijas indivīdu vidējās masas izmaiņas laikā. Šāda izteiksme izstrādāta liela izmēra zooplanktona sugai Calanus finmarchicus ar līdzīgu dzīves ciklu kā L.macrurus, tāpēc var tikt piemērota arī L.macrurus gadījumā:

$$
\mathrm{g}=\ln \left(\mathrm{W}_{\mathrm{t}+1} / \mathrm{W}_{\mathrm{t}}\right) / \mathrm{D}
$$

kur $\mathrm{W}_{\mathrm{t}+1}$ - populācijas indivīdu vidējā individuālā masa $(\mathrm{mg})$ laikā $\mathrm{t}+1, \mathrm{~W}_{\mathrm{t}}$ - populācijas indivīdu vidējā individuālā masa (mg) laikā t un D ir laika intervāls, kādā noteiktas izmaiṇas (dienas) (Campbell et al., 2001).

Lapkājvēžu produktivitātes noteikšanai vispirms aprēḳināts P/B koeficients, izmantojot modeḷa funkciju, kas izstrādāta pie dažādiem temperatūras apstakḷiem (Shuter, Ing, 1997):

$\log [\mathrm{P} / \mathrm{B}]=\alpha+\beta \mathrm{T}$,

$\operatorname{kur}[\mathrm{P} / \mathrm{B}]-\mathrm{P} / \mathrm{B}$ koeficients dienā, $\alpha$ un $\beta$ - taksona-specifiskas konstantes (lapkājvēžiem -1.725 un 0.444), bet $\mathrm{T}$ - ūdens temperatūra. Lapkājvēžu produkcija (P) aprēḳināta no iegūtā P/B koeficienta un biomasas vidē katrā no stacijām.

Kopumā līcī jūlijā bija vērojams nevienmērīgs zooplanktona sugu sastāva un biomasas sadalījums (2.attēls). Visaugstākā kopējā biomasa bija 10.stacijā, ko pamatā noteica B.coregoni proporcionāli lielais daudzums $(58 \%)$, tomēr š̄ lapkājvēža izplatība citās līča stacijās bija nevienmērīga. C.pengoi augstāko biomasu sasniedza DA dạ̦ā, bet sugas daudzums vidēji līcī nepārsniedza 10\% no kopējās zooplanktona biomasas. Atsevišķas zooplanktona sugas bija sastopamas tikai dažās stacijās. Piemēram, lielā izmēra airkājvēzis L.macrurus bija vērojams, galvenokārt, tikai DR un DA (53-83\%), kā rezultātā šajos rajonos kopumā veidojās augstāka zooplanktona biomasa nekā citos līča rajonos. Pārējās līča daḷās š̄̄ suga praktiski nebija sastopama. Pretēji L.macrurus, airkājvēža E.affinis biomasa D bija vairākas reizes mazāka nekā citos rajonos, bet Acartia spp. šeit nebija sastopama vispār. E.affinis galvenās koncentrācijas vietas bija ZA stacijās un Irbes jūras šaurumā, veidojot 21-55\% no kopējās biomasas. Acartia spp. dominēja Irbes jūras šaurumā, kur tās procentuālais daudzums sastādīja 37-51\%. Kopumā augstāka zooplanktona produkcija bija vērojama A un Irbes jūras šauruma rajonā (2.attēls). Salīdzinoši zemā produkcijas un biomasas attiecība DR-daļas stacijās skaidrojama ar proporcionāli lielo L.macrurus biomasu. Š̄̄s monocikliskās airkājvēža sugas reprodukcijas periods ir pavasarī, bet vasaras mēnešos sugas biomasas pieaugumu apmēri ir nelieli, kas 
nosaka produkcijas mazās skaitliskās vērtības. Z un ZA daḷā visaugstāko produkciju veidoja E.affinis, bet atsevišķās stacijās dominēja arī B.coregoni (10.stacija) un Acartia spp. (1. un 21.stacija) produkcija.

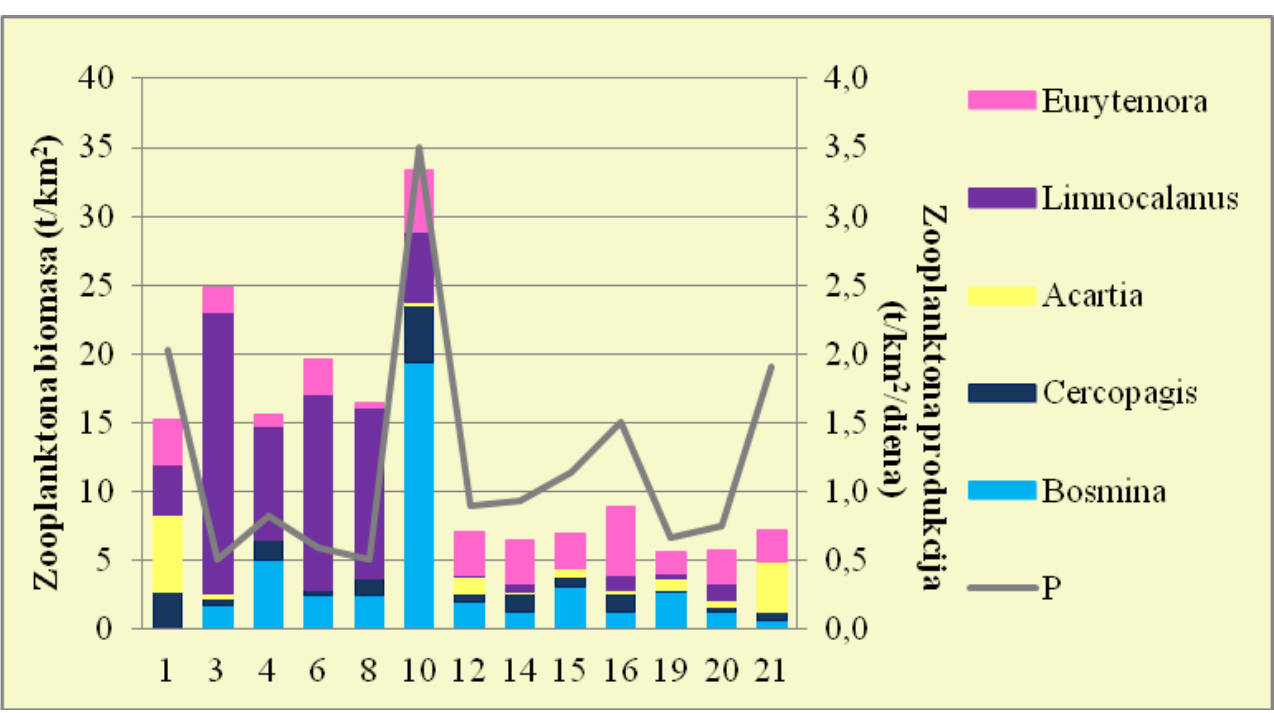

2. attēls. Zooplanktona sugu biomasas sadalījums un kopējā produkcija Rīgas līča stacijās 2011.gada jūlijā.

Līdzīgi kā zooplanktona gadījumā, arī rengées populācijas biomasas un vecuma struktūra līcī nebija homogēna (3. attēls). Vismazākais blīvums bija D un DR daḷā, bet augstākais centrālajā un ZR daḷā. Atšḳīāās arī vecuma struktūra - D un DR dạ̣ā vairāk koncentrējusies vecāka reņgée, savukārt Zdạ̦ā biežāk bija sastopamas jaunākās vecuma grupas (4.attēls), tomēr mazuḷu biomasa vidēji līcī nepārsniedza 10\% no kopējās reņǵes populācijas. Izņēmums bija Irbes jūras šaurums, kur jaunāko reṇgu biomasa sasniedza aptuveni 50\%.

Reņǵes barošanās analīzes rezultāti (LIMOD, 2012) norāda, ka reṇǵes barībā dominē E.affinis (aptuveni $50-90 \%$ ), bet pārējās sugas sastāda tikai $10-50 \%$ no kopējā apēstā barības daudzuma. Mazākās zivis papildus izvēlas Acartia spp. un B.coregoni, bet lielākās - C.pengoi (5.attēls). 


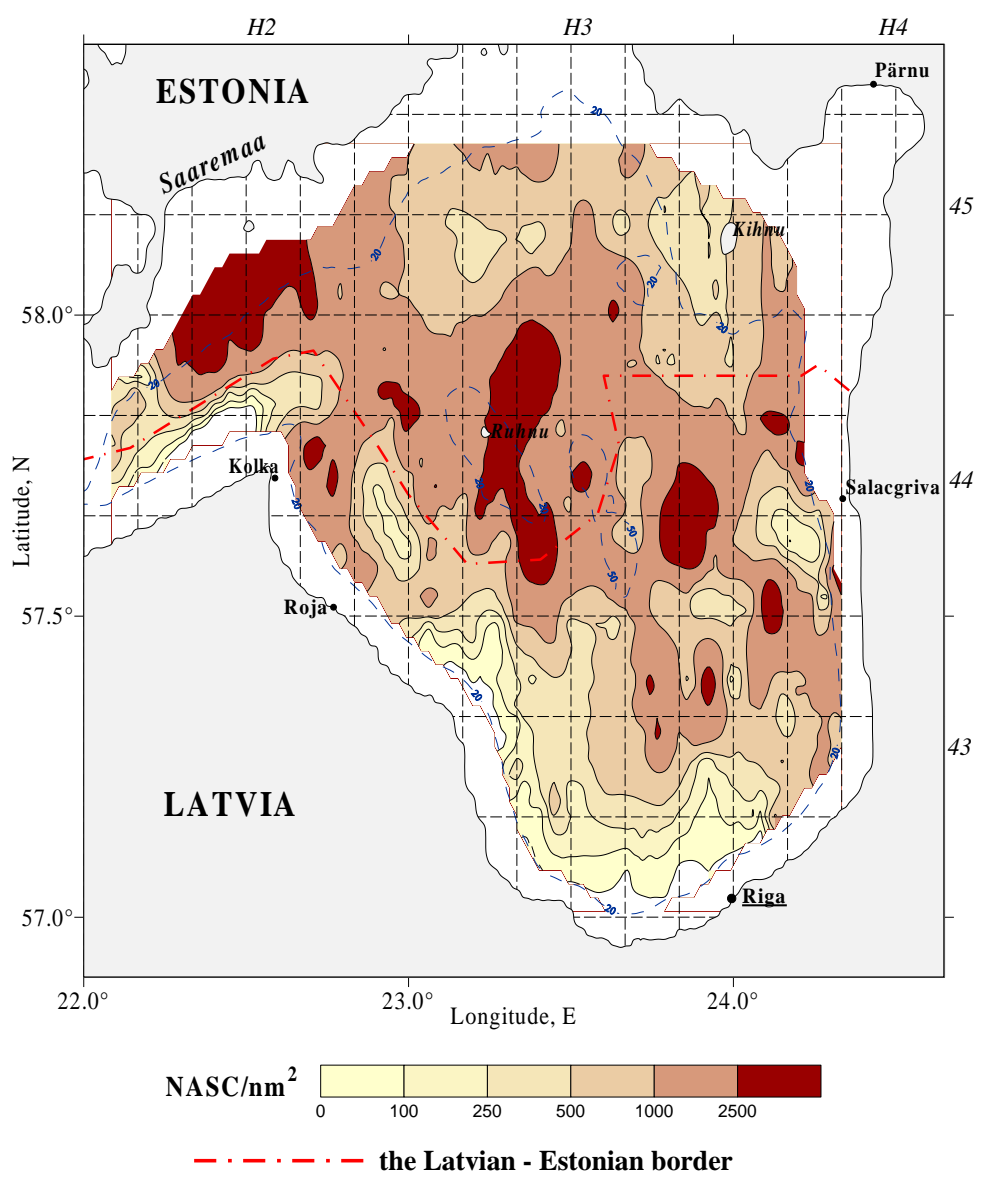

3. attēls. Reņges blīvuma sadalījums Rīgas līcī pēc Latvijas-Igaunijas apvienotā hidroakustiskā reisa rezultātiem (25.07 - 03.08.2011.).

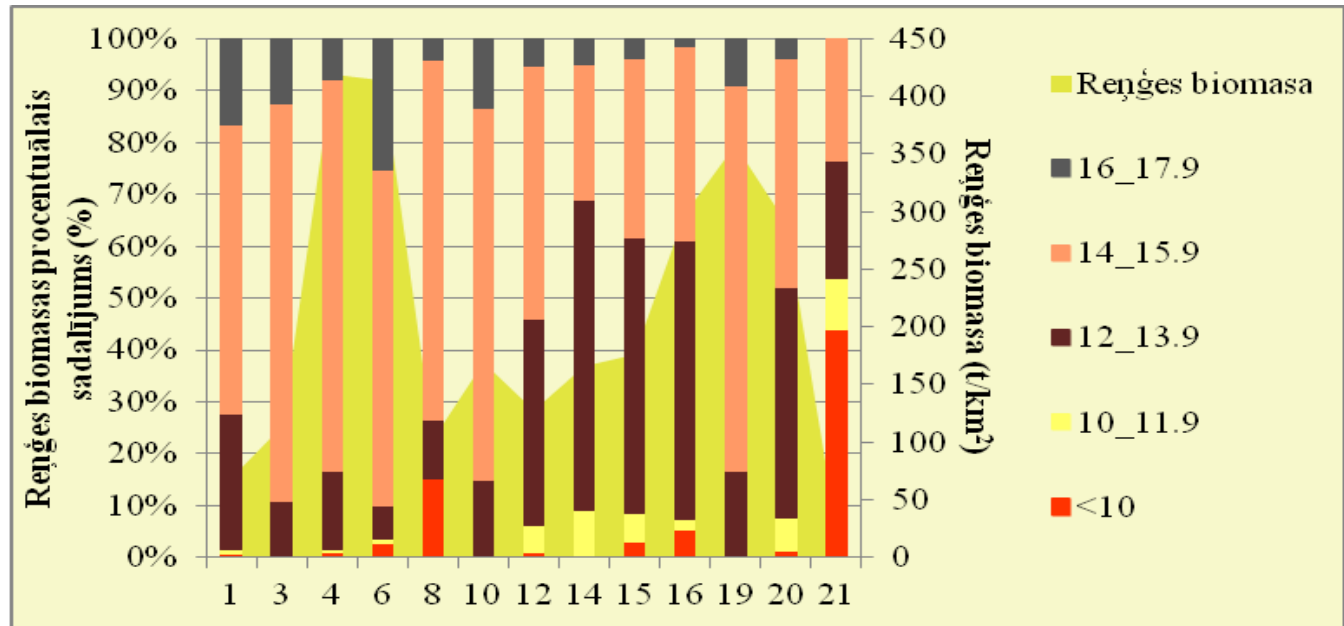

4. attēls. Reṇǵes biomasa un biomasas procentuālais sadalījums dažādās garuma grupās Rīgas līča stacijās 2011.gada jūlijā. 


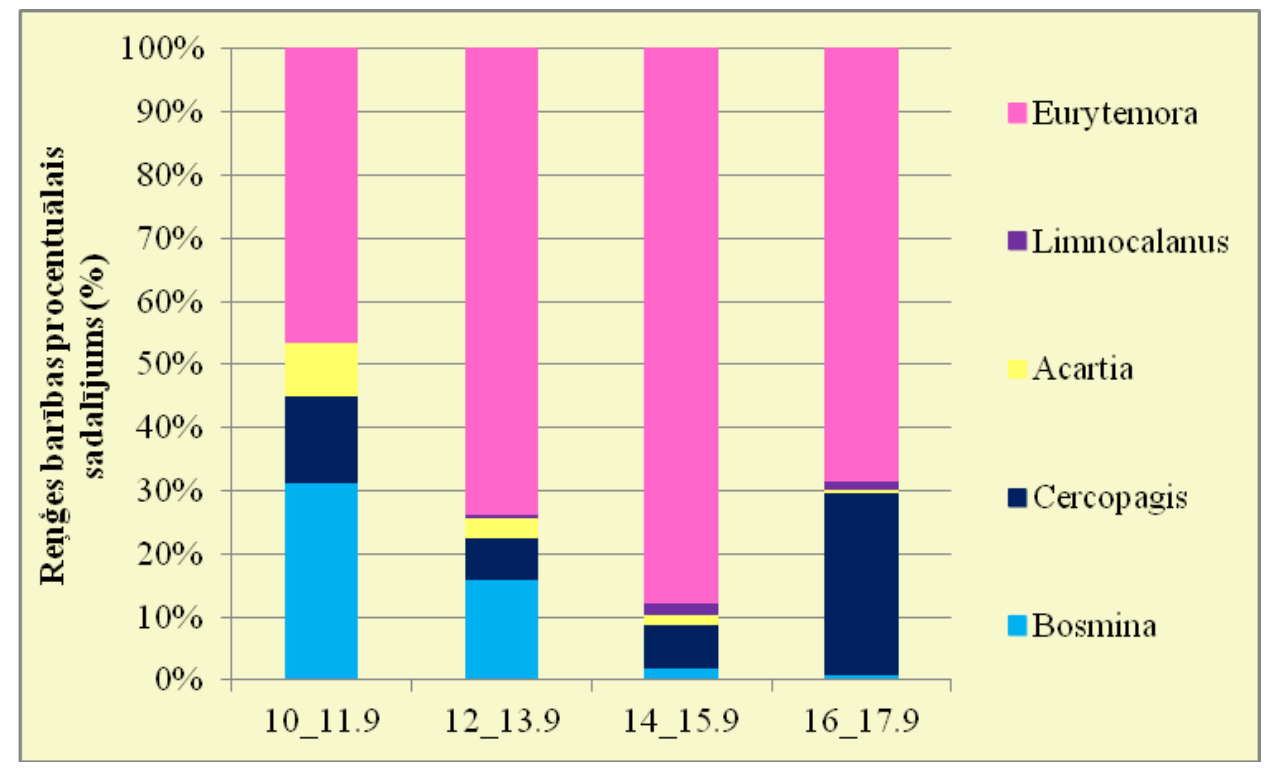

5.attēls. Reņgés barības procentuālais sastāvs dažādās zivju garuma grupās Rīgas līcī 2011.gada jūlijā.

Kopumā, neskatoties uz to, ka zooplanktona produkcija jūlijā ir viena no augstākajām gadā, produkcijas apjomi nespēj nodrošināt reṇges pieprasījumu pēc barības (6.attēls). Vidēji zooplanktona produkcija sastāda tikai $25 \%$ no tā, ko reņǵe spētu apēst. Zooplanktona atražošanās ātrums pārsniedz vai ir līdzvērtīgs nepieciešamajam zivju barības krājumu apjomam vien atsevišşās stacijās (1., 10. un 21.). Reņges barībā vasarā dominē E.affinis parstāvji un ir noskaidrots, ka sugas nozīme reņǵes barībā pieaug līdz ar zivju vecumu. N̦emot vērā E.affinis proporcionāli lielo daudzumu barībā, ir sagaidāms, ka izēšanas ietekme uz šiem planktona organismiem arī ir liela (6.attēls). Kā redzams 6.attēlā, praktiski visā līcī izēšanas ātrums ir vairākas reizes lielāks, nekā E.affinis spēja producēt. Vislielākā izēšana vērojama 4. un 6.stacijā, kur ir lielāks vecāko grupu reņgés īpatsvars (4.attēls), bet vismazākā ietekme uz sugu ir Irbes jūras šauruma rajonā. Attiecībā uz Acartia spp., tika noskaidrots, ka sugai priekšroku dod reṇgges mazuḷi. Šīs vecuma grupas lielākais blīvums ir Irbes jūras šaurumā un šeit noteikta arī visaugstākā Acartia spp. produkcija. Veiktie aprēķini norāda, ka mazuḷu ēšanas intensitāte tomēr nav tik liela, lai spētu izēst attiecīgās sugas daudzumu šajā rajonā. 2011. gada jūlijā Rīgas līcī bija salīdzinoši neliela L.macrurus biomasa un vietām suga praktiski nebija sastopama (2.attēls). 


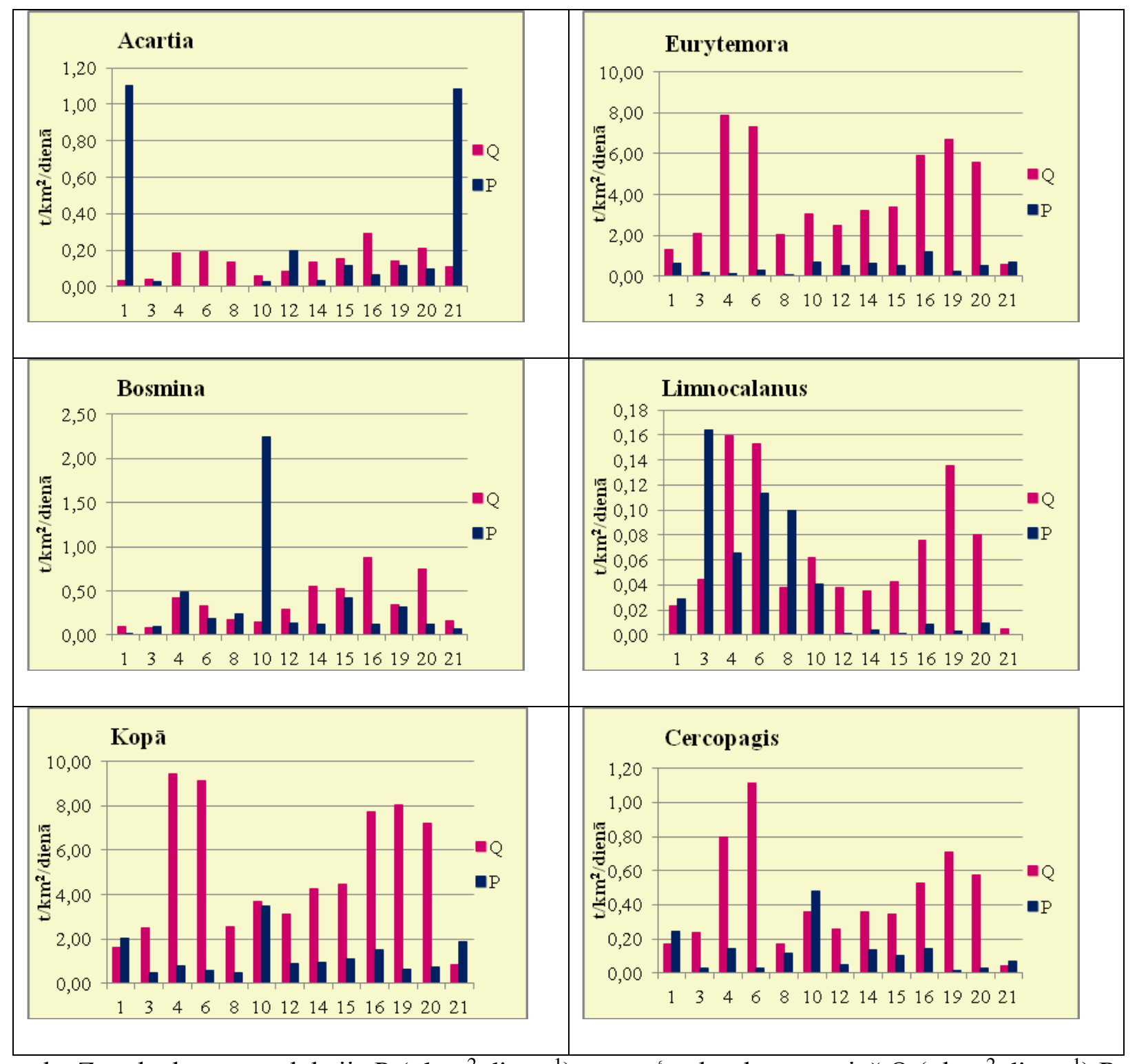

6. attēls. Zooplanktona produkcija $\mathrm{P}\left(\mathrm{t} \mathrm{km}^{-2}\right.$ diena $\left.^{-1}\right)$ un reṇges barības patēriņš $\mathrm{Q}\left(\mathrm{t} \mathrm{km}^{-2}\right.$ diena $\left.^{-1}\right) \mathrm{R}^{-1}$ gas līcī 2011.gada jūlijā dažādās stacijās.

Domājams, ka L.macrurus ir būtiska reņgés barības sastāvdaḷa un iespējams, ka līdz jūlijam liela daḷa populācijas ir tikusi izēsta. Tas varētu būt viens no iemesliem, kāpēc barības sastāvā sugas pārstāvju daudzums proporcionāli ir l̦oti mazs, kā rezultātā š̄ pētījuma rezultāti varētu nesniegt pietiekami drošu atbildi par rengges potenciālo ietekmi uz L.macrurus daudzumu līcī. Lapkājvēžu produkcijas spējas pie siltām temperatūrām ir augstas un, atšķirībā no airkājvēžiem, šo sugu biomasas 
pieaugumi vasarā var būt ḷoti strauji (Allan, 1976; Viitasalo et al., 1995). Ievērojamā B.coregoni un C.pengoi produkcija 10.stacijā (6.attēls) varētu liecināt par optimāliem augšanas apstākḷiem. No otras puses, šeit nav sastopamas jaunāko grupu reņǵes, kuras visintensīvak barojas ar B.coregoni. Lielāks barības patēriņš attiecībā uz šo sugu noteikts stacijās, kur vairāk zivju mazuḷi un jaunākās stadijas. Lielās reṇǵes labprātāk izvēlas enerǵētiski izdevīgāko lapkājvēžu sugu - C. pengoi, bet visbiežāk arī š̄s sugas produkcija neatbilst reņgés spējai to izēst.

Apkopojot iegūto informāciju, varam secināt, ka

1) zooplanktona izplatības atšķirības Rīgas līcī ir ievērojamas, ko nosaka nevienmērīgais zooplanktona sugu sastāvs, daudzums un atšķirīgā produkcija (P);

2) reņǵes barības patēriņš (Q) mainās atkarībā no reṇǵes populācijas vecuma struktūras un pieejamajiem barības objektiem vidē;

3) izēšana ir būtisks zooplanktona telpiskās izplatības, sugu sastāva un daudzuma noteicošais faktors vasarā - reṇges pieprasījums pēc barības vidēji 4 reizes pārsniedz zooplanktona produkcijas apjomus;

4) lai nodrošinātu sev labvēlīgus barošanās apstākḷus vasarā, reņǵei ir nepieciešams nepārtraukti pārvietoties - viens rajons nespēj ilgstoši nodrošināt reṇǵi ar nepieciešamo barības apjomu.

Pētîjums izstrādāts ar daḷēju ERAF projekta „Rīgas līča ekosistēmas funkcionālā modeḷa izstrāde efektīvas nacionālās politikas Baltijas jūras aizsardzībai nodrošināšanai un ilgtspējīgas ekosistēmas izmantošanas veicināšanai” (Nr.2010/0287/2DP/2.1.1.1.0/10/APIA/VIAA/040) un valsts pētījumu programmas projekta „Latvijas ekosistēmu vērtība un tās dinamika klimata ietekmē (EVIDEnT)” atbalstu.

\section{Izmantotā literatūra:}

Allan, J.D. 1976. Life history patterns in zooplankton. American Naturalist 110:165-180.

Campbell, R.G., Wagner, M.M., Teegarden, G.J., Boudreau, C.A., Durbin, E.G. 2001. Growth and development rates of the copepod Calanus finmarchicus reared in laboratory. Mar.Ecol.Prog.Ser., 221:161-183.

Cushing, D.H. 1995. The long-term relationship between zooplankton and fish. ICES J. Mar. Sci., 52(34):611-626. 
Hernroth, L. 1985. Recommendations on methods for marine biological studies in the Baltic Sea. Mesozooplankton biomass assessment. Baltic Marine Biologists Publ.: 32.

Hirst A.G., Sheader M. 1997. Are in situ weight-specific growth rates body-size independent in marine planktonic copepods? A re-analysis of the global syntheses and a new empirical model. Mar.Ecol.Prog.Ser. 154:155-165.

Huntley, M.E., Lopez, M.D.G. 1995. Temperature-dependent production of marine copepods: a global synthesis. The American naturalist, Vol.140, No.2:201-242.

ICES 2014a. Report of the Baltic Fisheries Assessment Working Group (WGBFAS). ICES Document CM 2014/ACOM: 10. 919. pp.

ICES. 2014b. Report of the Working Group on Zooplankton Ecology (WGZE), 24-27

March 2014, Reykjavik, Iceland. ICES CM 2014/SSGEF:09:42 pp.

Lankov, A., Ojaveer, H., Simm, M., Põllupüü, Möllmanns, C. 2010. Feeding ecology of pelagic fish species in the Gulf of Riga (Baltic Sea): the importance of changes in the zooplankton community. Journal of fish biology, 77: 2268-2284

LIMOD. 2012. Projekta „R̄̄gas līča ekosistēmas funkcionālā modeḷa izstrāde efektīvas nacionālās politikas Baltijas jūras aizsardzībai nodrošināšanai un ilgtspējīgas ekosistēmas izmantošanas veicināšanai", zinātniskais pārskats par 2011.gadu. 114.1pp.

Pauly, D., 1989. Food consumption by tropical and temperate fish populations: some generalizations. J. Fish Biol. 35(Suppl. A):11-20.

Peterson, W.T., Tiselius, P., Kiørboe, T. 1991. Copepod egg production, moulting and growth rates and secondary production, in the Skagerrak in August 1988. J. Plankton Res., 13:131-154.

Raid, T., Kornilovs, G., Lankov, A., Nisumaa, A-M., Shpilev, H., and Järvik, A. 2010. Recruitment dynamics of the Gulf of Riga herring stock: density-dependent and environmental effects. ICES Journal of Marine Science, 67:1914-1920.

Shuter, B.J., Ing, K.K. 1997. Factors effecting the production of zooplankton in Lakes. Can. J. Fish. Aquat. Sci., 54:359-377.

Valiela, I. 1995. Marine Ecological Processes. Springer, New York:686 pp.

Viitasalo, M., Vuorinen, I., Saesmaa, S. 1995. Mesozooplankton dynamics in the northern Baltic Sea: implications of variations in hydrography and climate. Journal of Plankton Research 17(10): 1857-1878.

Voss, R., Koster, F.W., Dickmann, M. 2003. Comparing the feeding habits of co-occuring sprat (Sprattus sprattus) and cod (Gadus morhua) larvae in the Bornholm Basin, Baltic Sea. Fisheries Research, 63:97-111. 
Берзиньш, В. 1987. Гидрологическое районирование открытой части Рижского залива. In: Гидрохимическая и гидробиологическая характеристика и районирование прибрежной части Балтийского моря, Рижского и Финского заливов. Ред. Андрушайтис Г.П., Лагановская Р.Ю., Апине С.О. Зинатне: 7-20. 


\section{VENTAS UN LIELUPES BASEINU UPJU EKOLOĢISKĀ STĀVOKḶAA NOVĒRTĒJUMS PĒC BIOLOĢISKAJIEM, HIDROMORFOLOĢISKAJIEM UN FIZIKĀLI ĶĪMISKAJIEM PARAMETRIEM}

\section{Agnija SKUJA*, Dāvis OZOLIN̦Š, Jolanta JĒKABSONE, Ilga KOKORĪTE, Laura GRĪNBERGA un EIga PARELE}

Latvijas Universitātes Biologiijas institūts, Hidrobiologijas laboratorija, Miera 3, Salaspils, LV-2169

*e-pasts: agnija@lanet.lv

Darba mērḳis bija noteikt Ventas un Lielupes upju baseinu apgabalu ūdensteču ekoloǵisko stāvokli pēc ES Ūdeṇu Struktūrdirektīvas noteiktajiem kritērijiem, pielietojot bioloǵiskos, hidromorfoloğiskos un fizikāli-ķ̄imiskos parametrus pēc Latvijas un Lietuvas pielietotajām sistēmām, lai noskaidrotu, kurus parametrus nepieciešams harmonizēt, lai pārrobežu upju ekologiiskā stāvokḷa novērtēšanai abas valstis kopīgās upes vērtētu pēc savstarpēji salīdzināmiem kritērijiem.

60 upju posmos (deviṇu Ventas baseina upju 26 posmos un 20 Lielupes upju 34 posmos) 2013. gada oktobrī un novembrī tika ievākti bentisko bezmugurkaulnieku paraugi, trīs sezonās (rudenī (2014. g.), pavasarī un vasarā (2015. g.)) veikti fizikāli - ķīmisko parametru mērījumi un ievākti paraugi ķ̄̄misko parametru analīzēm laboratorijā. Makrofìti 2015. gada vasarā pētīti 10 upju posmos. Visos punktos raksturoti hidromorfologiskie parametri pēc Lietuvas kritērijiem un papildus 26 punktos pēc Upju vides pētījuma metodes (River Habitat Survey (RHS)).

Bentisko bezmugurkaulnieku dati analizēti, aprēķinot Igaunijā un Lietuvā izstrādātos indeksus upju ekoloǵiskā stāvokḷa novērtēšanai - MMQ (Multimetric Quality) un LUMI (Lietuvas upju makrozoobentosa indekss). Abi indeksi veidoti pēc līdzīga principa. MMQ aprēḳināšanai izmanto piecus indeksus - kopējo taksonu skaitu, EPT taksonu skaitu, Šenona daudzveidības indeksu, ASPT un DSFI, savukārt LUMI indeksa aprēķināšanai - DSFI, ASPT, \#DEP (Diptera dzimtu, Ephemeroptera un Plecoptera sugu kopējais skaits) un \%EHP-\%CrHi* (atšķirība starp Ephemeroptera, Hemiptera, Plecoptera un Crustacea, Hirudinea īpatņu skaitu (\%)). Indeksi aprēḳināti arī 56 Lietuvas upju posmu 2013. gada monitoringa datiem. MMQ un LUMI vērtības savstarpēji korelēja un ekoloǵiskā stāvokḷa vērtējums pēc abiem indeksiem bija vienāds 67 \% upju posmu. Igaunijā izstrādātais MMQ indekss Latvijas upēs atspoguḷoja zemāku kvalitāti, kā Lietuvā izstrādātais LUMI indekss.

10 Latvijas upju posmu kvalitāte tika novērtēta pēc Polijas upju makrofitu indeksa (Polish Macrophyte Index for Rivers (MIR)), vidējā trofiskuma līmeṇa indeksa (Mean Trophic Rank (MTR)) 
un upju bioloǵiskā makrofìtu indeksa (Biological Macrophyte Index of Rivers (IBMR). Ekoloğiskā stāvokḷa novērtējums būtiski atšḳ̄īās: MTR indekss atspoguḷoja zemāku ekoloǵisko stāvokli apsekotajos upju posmos, savukārt Polijas MIR indekss - augstāku. Pēc trīs izmantotajiem indeksiem neviena no pētītajām vietām netika novērtēta vienādi.

Vērtējot upju ekoloǵisko stāvokli pēc Lietuvas fizikāli - ķīmisko parametru kritērijiem, ekoloǵiskā stāvokḷa novērtējums bija augstāks nekā vērtējot pēc Latvijas kritērijiem.

Lietuvas upju morfologijas novērtēšanas metode (HMIu indekss) tika testēta 60 vietām un HMIu indekss salīdzināts ar RHS vērtējumu 26 vietām. RHS vērtējums balstīts uz Vides kvalitātes novērtējuma (Habitat Quality Assessment score (HQA)) un Vides modifikācijas (Habitat Modification Score (HMS)) indeksu vērtībām. HMIu vērtības vienlīdz būtiski korelēja gan ar HQA, gan ar HMS indeksu, kaut gan sakarības starp HQA un HMS bija vājākas, taču būtiskas, jo tie veidoti pēc atšķirīgiem principiem. HMIu indekss tika izstrādāts, lai novērtētu antropogēnās ietekmes izraisītās izmaiṇas dabiskajos apstākḷlos un, spriežot pēc rezultātiem, atspoguḷo gan biotopa pārveidošanas ietekmi, gan netiešā veidā - biotopa kvalitāti.

Analizējot ekoloǵiskā stāvokḷa novērtējumu kvalitātes klasēs pēc bioloǵiskajiem kvalitātes elementiem un tā sakarības ar novērtējumu pēc fizikāli ķīmiskajiem un hidromorfologiskajiem kritērijiem, konstatēta atšķirīga atsevišķu bioloǵiskas kvalitātes elementu indeksu vērtējuma atbilstība dažādām kvalitātes klasēm, izmantojot Lietuvas un Latvijas fizikāli ķīmisko parametru kritērijus. Piemēram, makrofìtu MTR indekss konstanti pazemināja ekoloǵisko stāvokli, salīdzinot ar vērtējumu pēc Lietuvas fizikāli ķīmiskajiem kritērijiem.

Visi testētie bentisko bezmugurkaulnieku indeksi būtiski korelēja ar ekoloǵiskā stāvokḷa novērtējumu pēc Lietuvas fizikāli ķīmisko rādītāju kritērijiem, bet neviens no tiem nekorelēja ar vērtējumu pēc Latvijas fizikāli ķīmiskajiem kritērijiem. Visi bentisko bezmugurkaulnieku indeksi uzrādīja labāku stāvokli kā Lietuvas un Latvijas fizikāli ķīmiskie parametri. Salīdzinot ar Lietuvas kritērijiem, atšḳirība galvenokārt bija par vienu kvalitātes klasi, taču, salīdzinot ar Latvijas kritērijiem par divām vai pat trīs kvalitātes klasēm. Vairumā gadījumu atškirīības ekologiskāa stāvokḷa vērtējumā

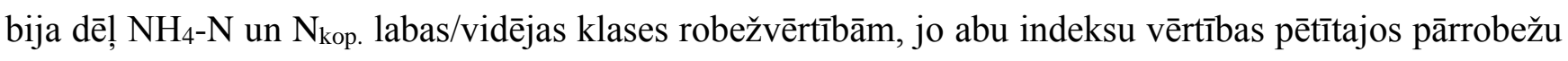
upju posmos būtiski korelēja šo parametru vērtībām. Vietās, kas pēc MMQ un LUMI indeksa tika novērtētas ar labu ekologisko stāvokli, vidējās $\mathrm{NO}_{3}-\mathrm{N}$ vērtības pēc Lietuvas kritērijiem nitrātu

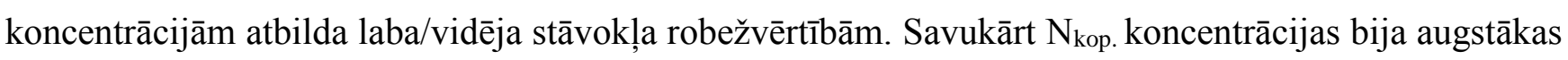


nekā laba/vidēja stāvokḷa klašu robežvērtībām pēc Lietuvas sistēmas un daudz augstākas - pēc Latvijas sistēmas.

Abu valstu hidromorfoloǵiskie indeksi korelēja gan ar bentisko bezmugurkaulnieku indeksiem, gan savstarpēji un ir salīdzināmi. Vien̄̄gi HQA indeksam bija mazāk izteiktas sakarības ar bentisko bezmugurkaulnieku indeksiem un HMS indeksu. Latvijas testētā hidromorfologiskāa novērtējuma sistēma atbilst ES ŪSD noteiktajiem kritērijiem, bet Lietuvas HMIu indeksā nav ieklautas visas hidromorfoloǵiskās pazīmes, kas ir noteiktas Eiropas Standartā. Indeksā iekḷautas tikai tās pazīmes, kurām pierādīta ietekme uz stāvokḷa novērtējumu pēc bioloǵiskās kvalitātes elementiem. Tomēr, veidojot monitoringa programmu, būtu jāiekḷauj visi Standartā noteiktie hidromorfologiiskie parametri.

Lai nodrošinātu harmonizētu un reprezentatīvu pārrobežu upju ekoloǵiskā stāvokḷa novērtējumu, rekomendējams, pārskatīt labas/vidējas kvalitātes klases robežvērtības fizikāli ķīmiskajiem elementiem. Šobrīd Latvijā 1. perioda upju baseinu apsaimniekošanas plānos izmantoto fizikāli ķīmisko kritēriju robežvērtības labai/vidējai ekolog̣iskās kvalitātes klasei, salīdzinot ar Lietuvas kritērijiem, ir stingrākas un nav harmonizētas ar bioloǵisko elementu robežvērtībām.

Latvijā un Lietuvā izmantotās bentisko bezmugurkaulnieku indeksu un hidromorfoloǵiskā vērtējuma sistēmas ir saskaņotas un sniedz līdzīgu ekologiskā stāvokḷa novērtējumu.

Pētījums realizēts Latvijas - Lietuvas 2007. - 2013. gada pārrobežu sadarbības programmas projekta "Lielupes un Ventas upju baseinu apgabalu upju monitorings un lauksaimnieku aptauja par vides aizsardzības jautājumiem" ietvaros.

\section{Izmantotā literatūra:}

Virbickas T., Valatka S, Skuja A., Birzaks J., Grīnberga L., Kokorīte I., Jēkabsone J, Ozoliņ̌̌ D. 2014. Report on Ecological Status and recommendations for Unification of River Assessment Methods for Transboundary Lithuanian Latvian Rivers. Technical Report. 113.

(http://www.lubi.edu.lv/files/File/LatLit_WBstatus_assessment_final_report_10_2014_LLIV_230_LiVe_RiverB asins.pdf). 


\title{
SVEŠO SUGU MONITORINGS BALTIJAS JŪRAS OSTĀS
}

\section{Solvita STRĀĶE ${ }^{1 *}$, Ieva BĀRDA ${ }^{1}$, Astra LABUCE ${ }^{1}$, Viktors PĒRKONS ${ }^{1}$, Svetlana ROMANOVIČA ${ }^{1}$}

\author{
Latvijas Hidroekologijas institūts, Daugavgrīvas ielā 8, Rīga, LV-1048 \\ *e-pasts: solvita.strake@lhei.lv
}

Jūras stratēgijas pamatdirektīva (JSD) nosaka nepieciešamību visām Eiropas Savienības dalībvalstīm sekot līdzi savas jūras ūdeṇu dzīvotnēm un to bioloğisko īpašību izmaiṇām. Informācijas uzkrāšana par Baltijas jūrai svešu sugu esamību / neesamību, sastopamību, skaitu un izplatību ir l,oti nozīmīga, lai saskaṇā ar JSD paredzētajiem mērḳiem vides jomā raksturlielumā D2 „Svešzemju sugas” noteiktu piemērotus radītājus / indikatorus laba vides stāvokḷa raksturošanā. Šobrīd informācija par Baltijas jūrā sastopamajām svešajām sugām tiek iegūta bioloǵisko datu vākšanas monitoringa programmā. Tomēr dati par bioloǵiskajiem parametriem ir l̦oti nepilnīga, tā piemēram, Latvijas jūras ūdeņos esošā monitoringa programma neietver seklus piekrastes ūdeņus, kā rezultātā netiek iegūta informācija par vairākām cietajās gruntīs mîtošajām zivju, vēzī̌su un divvāku gliemeņu sugām. Papildus tam, lai iegūtu informāciju par jaunu svešo sugu introdukciju un izplatību, ir ļoti svarīgi Baltijas jūras monitoringa programmu papildināt ar sugu apsekojumiem ostu rajonos. Saskaņota monitoringa programma ostu rajonos būtiski atvieglos ar konvencijas par Kuǵu balasta ūdeņu un nosēduma kontroli un pārvaldību ieviešanu saistītos vides jautājumus un dos ieguldījumu Jūras stratēǵijas pamatdirektīvas mērķu sasniegšanā.

Pētîjuma mērķis ir pārbaudīt esošo un jaunu monitoringa metožu pielietojamību svešo sugu ievākšanai Latvijas ostās analizējot svešo sugu sastopamību un skaitu dažādos vides apstākḷlos. Paraugu ievākšanas metodes tika testētas Liepājas ostā 2013.gada septembrī, 2014.gada maijā un oktobrī, Rīgas ostā 2014.gada septembrī. Katrā ostas paraugu ievākšanas stacijā tika analizēti vides dati kā Seki dziḷums, ūdens temperatūra, ūdens sāḷums, hlorofila $a$ koncentrācija u.c. Bioloǵiskajos apsekojumos fitoplanktona datu ievākšanai izmantots Horizontālais ūdens paraugu ievākšanas batometrs, zooplanktona datu ievākšanai - Apšteina tīkliņš (tīkla acu izmērs $53 \mu \mathrm{m}$ ), mīkstās grunts paraugu ievākšanai izmantots Ponora tipa kauss, organismiem, kuru attīstībai nepieciešams ciets substrāts, izmantotas īpašas nosēdināšanas plates, krabju iegūšanai izmantoti krabju ķeramie tīkli un apaugumu ievākšanai izmantots skrāpis. Rezultāti rāda, ka svešo sugu iegūšanai izmantotās metodes ir daudzsološas un potenciāli var tikt izmantotas svešo sugu monitoringam ostu rajonos. 
Pētījums veikts ar Helcom "Baltic Sea Pilot Project: Testing new concepts for integrated environmental monitoring of the Baltic Sea“, 2013.-2015.gads un Valsts Pêtījumu Programmas „Latvijas ekosistēmu vērtîba un tās dinamika klimata ietekmē (EVIDEnT)”, 2014.-2017.gads atbalstu. 


\section{SĀNPELDES KĀ RĪGAS LĪČA SEDIMENTU KVALITĀTES INDIKATORS Evita STRODE ${ }^{1 *}$, Maija BALODE ${ }^{1,2}$ \\ ${ }^{1}$ LU Biologijas fakultāte, Hidrobiologijas katedra, \\ ${ }^{2}$ Latvijas Hidroekologijas Institūts, Eksperimentālās Hidrobioloğijas nodaḷa \\ *e-pasts: evitast@lanet.lv}

Sedimentu kvalitātei ir izšķiroša nozīme ūdenstilpju ekosistēmas funkcionēšanā. Sedimenti ir ne tikai bentisko organismu mājvieta, bet veic arī galējo dabīgā un antropogēnā piesārṇojuma uztvērēju funkciju, jo tajos akumulējas visdažādākās sadzīvē, lauksaimniecībā un rūpniecībā izmantotās organiskās (naftas produkti, pesticīdi, virsmas aktīvās vielas, fenoli, hlororganiskie savienojumi u.c.) un neorganiskās vielas (smagie metāli, biogēnie elementi u.c.). Ķīmiski piesārṇoti sedimenti var būt tieši toksiski ūdens organismiem, kā arī toksiskās vielas var akumulēties barības ķēdē (ASTM, 2003). Cilvēkam visbīstamākā ir šo savienojumu koncentrācijas palielināšanās barības ķēdes pēdējā posmā plēsējos. Piesārṇojošo vielu koncentrācija sedimentos nereti ir vairākas reizes augstāka nekā ūdenī, jo sedimentu ḳīmiskais sastāvs spēj ilglaicīgi piesaistīt piesārṇojumu un lēni noārdās.

Daudzas bentisko bezmugurkaulnieku sugas var pilnībā izzust vai kḷūt par piesārṇojuma tolerantām sugām, ietekmējot ekosistēmas funkcijas, ieskaitot produktivitāti (Hoffman et al., 2003). Lai noskaidrotu vai sedimentu piesārņojums ir kaitīgs bentiskajiem organismiem un, kā tas ietekmē ekosistēmu, tiek veikta to biotestēšana, kā testa indikatorus izmantojot bentiskos organismus, tai skaitā sānpeldes.

Pierādīts, ka sānpeldes ir jūtīgi indikatori sedimentu piesārn,ojuma noteikšanai (Fuchsman et al., 1998), jo palielinoties piesārṇojumam, attiecīgi samazinās sānpelžu populācijas blīvums, kā arī tiek novērotas subletālas iedarbības sekas - izmaiṇas augšanā un metālu akumulācija organisma audos (Levent, 2005). Sedimentu testa rezultātu interpretācijā liela nozīme ir testorganisma izvēlei. Izvēloties testorganismus ir svarīgi noskaidrot to jūtību, uzglabāšanas un kultivēšanas iespējas laboratorijas apstākḷos (Hoffman et al., 2003).

Darba mērḳis ir noteikt Rīgas līča sedimentu ekoloǵisko kvalitāti, kā testa organismus izmantojot sānpeldes. 
Rīgas līča sedimenti tika ievākti no 24 piekrastes un dziḷūdens stacijām (laika posmā no 2010. līdz 2013. gadam). Piekrastes stacijas atrodas līča transporta zonā un tām raksturīgi rupjāki smiltsmāla, mālsmilts sedimenti, bet dziḷās stacijas - līča akumulācijas zonā, kam raksturīgi smalki, dūṇaini sedimenti, kas labāk akumulē piesārņojumu. Biotestēšana (akūta 10 dienas un hroniska 42 dienas) tika veikta ar Baltijas jūras dominējošām sānpelžu sugām - Monoporeia affinis, Pontogammarus robustoides, Corophium volutator, Bathyporeia pilosa, kā arī starptautiski atzītu standartsugu Hyalella azteca, iegūta no Chesapeake kultūras kolekcijas (Chesapeake Culture collection of Hayes. VA, USA) un adaptēta atbilstoši Rīgas līča vides apstākḷiem.

Abiotiskie vides faktori ietekmē organismu eksistenci, daudzveidību un sastopamību. Noskaidrojot sānpelžu toleranci pret temperatūras svārstībām, tika konstatēts, ka visas testiem izvēlētās sugas raksturojas ar iespējām izdzīvot plašā temperatūras diapozonā $\left(4-16{ }^{\circ} \mathrm{C}\right)$ pēc 14 dienu ekspozīcijas izdzīvotībai pārsniedzot 80 \%, izṇemot $H$. azteca, kuras augšanas temperatūra ir $\geq 20{ }^{\circ} \mathrm{C}$. Sedimentu kvalitātes noteikšanai tika izmantotas standartā (ISO, 2005) noteiktās testa temperatūras vai testorganismu dabiskās dzīvotnes temperatūras.

Metodoloǵiskie pētījumi parādīja paraugu uzglabāšanas, ievākšanas sezonalitātes un testorganismu attīstības lomu nozīmību sedimentu kvalitātes kontrolē. Tika konstatēts testos ar $B$. pilosa būtisks paraugu toksiskuma pieaugums pēc to sasaldēšanas un atkausēšanas, attiecīgi vidēji samazinot organismu izdzīvotību par $30 \%$ nekā nesaldētos paraugos, savukārt $M$. affinis un $P$. robustoides atškirīības sastādīja $12 \%$ un $5 \%$. Rudens sezonā ievāktajiem paraugiem ar C. volutator un M. affinis tika noteikta zemāka organismu izdzīvotība (76\% - 85\%), kas iespējams saistīts ar sedimentu apmaiṇas procesa sezonālo dinamiku rudens periodā vai organismu nobriešanu apaugḷošanās periodam. Testorganismu attīstības loma sedimentu biotestēšanā uzskatāmi parādījās $P$. robustoides gadījumā, kad jaundzimušie indivīdi potenciāli piesārṇotu sedimentu klātbūtnē uzrādīja augstāku izdzīvotību salīdzinājumā ar pieaugušajiem īpatņiem. Vismazākās toksikorezistences atškirīibas atkarībā no vecuma tika konstatētas $M$. affinis gadījumā, vidējai izdzīvotībai Rīgas līča sedimentu klātbūtnē visās vecuma grupās sastādot 93-96 \%.

Testorganismu izvēlē vadījāmies pēc iepriekšējos pētījumos noteiktām sānpelžu sugu toksikorezistences atšķirībām references toksikantu (smago metālu) klātbūtnē, kas izpaudās sekojošā secībā: H. azteca > P. robustoides > B. pilosa > C. volutator > M. affinis (Strode and Balode, 2013). 
Par dziļūden̄ī mītošās sānpeldes $M$. affinis augsto toksikorezistenci liecina arī Rīgas līča sedimentu biotestēšanas rezultāti, organismu izdz̄ivotībai sedimentu klātbūtnē svārstoties no 73 \% līdz $100 \%$ (vidēji 92 \%), zemākos izdzīvotības rādītājus uzrādot Rīgas līča centrālajā 121. stacijā un Igaunijas ziemeḷaustrumu teritorijas stacijās (125. un K21.). Rīgas līča sedimentu toksiskuma novērtējums ar M. affinis uzrāda, ka 83 \% gadījumos sedimentu paraugi uzskatāmi par netoksiskiem un $17 \%$ gadījumos paraugi raksturojas ar zemu toksikumu, nepārsniedzot $20 \%$ organismu mirstību (1. tabula).

Testos ar otru ISO (2005) standartsugu C. volutator uzrāda, ka $62 \%$ gadījumos sedimentu paraugi (1. tabula) ir ar zemu toksiskumu, organismu izdzīvotībai sedimentu klātbūtnē svārstoties no 60 \% līdz 100 \% (vidēji 84 \%), zemākos izdzīvotības rādītājus uzrādot Rīgas līča centrālās daļas stacijās (119., 120. un 121).

Ar salīdzinoši zemākiem izdzīvotības rādītājiem Rīgas līča sedimentos raksturojās sānpelžu sugas - B. pilosa un $P$. robustoides, izdzìvotībai sedimentu klātbūtnē attiecīgi svārstoties no 28 \% līdz $100 \%$ (vidēji $73 \%$ ) un $31 \%$ līdz $88 \%$ (vidēji $65 \%$ ), zemākos rādītājus uzrādot Rīgas līča centrālās daḷas stacijā (121.) un Rīgas līča austrumu daḷā pretī Engurei un Mērsragam. Rīgas līča sedimentu biotestēšana apstiprināja references testa rezultātus, kas liecina par $P$. robustoides un $B$. pilosa paaugstinātu jutību pret potenciāli toksisku vielu klātbūtni, norādot par to piemērotību sedimentu toksiskuma noteikšanā. 1. tabula.

1. tabula. Rīgas līča sedimentu toksiskuma novērtējums (\%) pēc sānpelžu izdzīvotības.

\begin{tabular}{|l|c|c|c|c|c|}
\hline Toksiskuma novērtējums & M. affinis & C. volutator & B. pilosa & P. robustoides & H. azteca * \\
\hline $\begin{array}{l}\text { Nav toksiski } \\
\text { Izdzīvotība }(>90 \%)\end{array}$ & 83 & 31 & 39 & 10 & 17 \\
\hline $\begin{array}{l}\text { Zems toksiskums } \\
\text { Izdzīvotība (90-80\%) }\end{array}$ & 17 & 62 & 17 & 38 & 33 \\
\hline $\begin{array}{l}\text { Vidējs toksiskums } \\
\text { Izdzīvotība (80-50\%) }\end{array}$ & 0 & 8 & 33 & 43 & 50 \\
\hline $\begin{array}{l}\text { Augsts toksiskums } \\
\text { Izdzīvotība (<50\%) }\end{array}$ & 0 & 0 & 11 & 10 & 0 \\
\hline
\end{tabular}

* tikai centrālās daḷas stacijās 
Rīgas līča sedimentu biotestēšana ar starptautiski atzītu standartsugu $H$. azteca diemžēl tika veikta tikai centrālā rajona stacijās (119., 120. un 121.), organismu izdzīvotībai sedimentu klātbūtnē sastādot no $60 \%$ līdz $93 \%$ (vidēji $72 \%$ ), kā arī $50 \%$ gadījumos sedimentu paraugi raksturojas ar vidēju toksiskumu (1. tabula).

Veicot hroniskos pētījumus ar H. azteca tika konstatēti reprodukcijas un embriologiskās attīstības traucējumi. Testa perioda beigās (42 dienā) H. azteca izdzīvotība tika konstēta salīdzinoši zema 119. un 121. stacijās, attiecīgi $15 \%$ un $43 \%$, savukārt 120. stacijā tā bija augsta $80 \%$. Mātītēm, kuras attīstījušās 119. un 121. stacijas sedimentos tika konstatēts pat $39 \%$ un $61 \%$ ietekmētu embriju no kopējā olu skaita.

Kopumā biotestēšanas rezultāti uzrāda Rīgas līča sedimentu (1. tabula) zemu/vidēju toksiskumu, jo biotestos izmantoto sānpelžu sugu vidējā izdzīvotība ir tuvu 80 \%. Sedimentu kvalitātes ziņā netika konstatētas būtiskas atškirības starp Rīgas līča rajoniem - sānpelžu izdzīvotībai līča rietum- un centrālā daḷas sedimentos, vidēji sastādot $85 \%$, bet austrumu daḷas sedimentos $-87 \%$ Kā izṇēmums $P$. robustoides un $B$. pilosa biotestos tika kontatēts, ka 10-11 \% gadījumos Rīgas līča centrālā daḷas sedimentu paraugi (1. tabula) uzrādīja augstu toksiskumu, organismu mirstībai pārsniedzot 50 \%.

Rīgas līča sedimentu biotestēšana nenoliedzami liecina par abu ISO standartā ieteikto sānpelžu M. affinis un $C$. volutator augsto-, bet $H$. azteca, $P$. robustoides, B. pilosa zemo toksikorezistenci pret potenciālo piesārņojumu, kurus būtu ieteicams rekomendēt, kā testobjektus sedimentu biotestēšanai. Rezultāti liecina par paraugu uzglabāšanas veida un organismu attīstības stadijas būtisko lomu biotestu veikšanā.

Kopumā jāsecina, ka potenciālais Rīgas līča sedimentu toksiskais piesārņojums var būtiski ietekmēt sānpelžu populācijas izdzīvošanu un reproducējošās sistēmas kvalitāti. Pētījumi pierāda, ka sānpelžu izdzīvotības un reprodukcijas spēju noteikšana var tikt izmantots kā indikators sedimentu kvalitātes kontrolē un apstiprina hronisko testu veikšanas nepieciešamību sedimentu potenciāli toksiskā piesārņojuma noteikšanai.

\section{Izmantotā literatūra:}

ASTM. 2003. American Society for Testing and Materials. Standard test method for measuring the toxicity of sediment-associated contaminants with estuarine and marine amphipods. ASTM E1367-03. 
Fuchsman P.C., Barber T.R., Sheehan P.J. 1998. Sediment Toxicity Evaluation for Hexachlorobenzene: Spiked Sediment Tests with Leptocheirus plumulosus, Hyalella azteca, and Chironomus tentans. Arch. Environ. Contam. Toxicol. 35: 573-579.

Hoffman D. J., Rattner B. A., Burton G. A., 2003. Handbook of ecotoxicology. CRC Press, 1290 pp. ISO. 2005. Ūdens kvalitāte. Jūras vai grīvas sedimentu akūtās toksicitātes noteikšana uz sānpeldēm (Amphipoda). LVS EN ISO 16712:2007 standarta testa procedūra. VSIA Latvijas Standarts. 16 lpp.

Levent B. 2005. A review of sediment toxicity bioassays using the amphipods and polychaetes. Turkish Journal of Fisheries and Aquatic Sciences 5:119-139.

Strode E. and Balode M. 2013. Toxico-resistance of Baltic Amphipod species to heavy metals. Crustaceana 86 (7-8): 1007-1024. 


\title{
SIVERA EZERA DABAS VĒRTİBAS SMALKĀS UN LOKANĀS NAJĀDAS (NAJAS TENUISSIMA, N. FLEXILIS) ATRADṆU AIZSARGĀŠANAS KONTEKSTĀ
}

\author{
Uvis SUŠKO \\ Latvijas Botāniķu biedrība \\ *e-pasts: uvis.susko@inbox.lv
}

2013. gada vasarā un rudenī ar Latvijas Vides aizsardzības fonda (LVAF) finansiālu atbalstu tika īstenots Dabas aizsardzības pārvaldes projekts „Eiropas Savienības Biotopu direktīvas II pielikuma sugas smalkās najādas Najas tenuissima atradnes izpēte potenciālas jaunas īpaši aizsargājamas teritorijas dibināšanai vai esošās teritorijas paplašināšanai”, kā ietvaros tika apsekota 746 ha liela platīiba ar Ārdavu un tā apkārtējo teritoriju. Ar LVAF atbalstu Sauleskalna apkārtnes dziḷo ezeru izpēte saistībā ar pasaulē un Eiropā l’oti reto un relikto, Eiropas Savienības Sugu un biotopu direktīvas II un IV pielikumā iekḷauto sugu - smalkās Najas tenuissima un lokanās najādas N. flexilis izplatības un populāciju stāvokḷa noskaidrošanu 2014. gada vasarā un rudenī tika turpināta Dabas aizsardzības pārvaldes projekta „Trīs īpaši aizsargājamu dabas teritoriju statusa izvērtējums” ietvaros, kā rezultātā tika detalizēti apsekots Sivera ezers ar apkārtējo teritoriju 4585,0 ha platībā. Apsekotajā teritorijā ietilpst 1822,6 ha liela ezeru platība, ko veido 1784,8 ha lielais Sivers ar 26 salām un četri mazie ezeri Lubonen̦š, Kauseņš, Margaucis, Teneiss ar kopējo platību 37,8 ha, kā arī 2736,4 ha liela ezeru krastu platība un 26,0 ha liela dīḳu platîba (Krāslavas novada Aulejas, Kombuḷu un Skaistas pagasti, Dagdas novada Konstantinovas pagasts). Teritorijas apsekošana aizņēma 45 lauka dienas un to veica sertificēti sugu un biotopu eksperti - U. Suško (33 dienas), R. Sniedze-Kretalova (7 dienas) un V. Baroniņa (5 dienas). Sivera apsekošanā visā krasta līnijas garumā tika pavadītas 18 lauka dienas (U. Suško), mazo ezeru apsekošanā -2 lauka dienas (U. Suško), bet sauszemes apsekošanā - 26 lauka dienas (U. Suško, R. Sniedze-Kretalova, V. Baroniņa).

Sivers ir caurtekošs, vāji eitrofs dzidrūdens glaciālas izcelsmes klajumu ezers, kas pieder Daugavas sateces lielbaseinam un tajā ietilpstošajam Dubnas sateces baseinam (Eipurs, 1998). Ezera sateces baseina platība ir aptuveni $84 \mathrm{~km}^{2}$, ko veido $13 \%$ meži, $37 \%$ - ezeri un $50 \%$ lauksaimniecības zemes (Bērziṇš, 1943; Eipurs, 1998). Jāpiezīmē, ka ap 1960. gadu vidu Sivera sateces baseins tika 
mākslīgi palielināts, novadot uz Sivera austrumu daḷas Vonogišku līci Būkštu purva un purvaino mežu humusvielām bagāto ūdeņu noteci, kā dabiskā notece ietilpa Ižiuna ezera sateces baseinā. Tas noteikti ir radījis un joprojām rada negatīvu ietekmi uz Sivera ezera austrumu daḷas ekoloǵisko stāvokli, no salīdzinoši plašas teritorijas ievadot papildus biogēnos elementus un humusvielām bagāto ūdeni, kas samazina Sivera ūdens dzidrību un kvalitāti. Siverā ietek Dubna no Ojatu ezera ziemeḷos, par kanālu pārveidotā Kovšika no Kauseņa un Iuzupe no Teneisa dienvidos, Zviergzdupe pie Brāslavas rietumos, kā arī vismaz 16 grāvji. Ezera rietumu galā iztek Dubna un aptuveni pirms 10 gadiem izraktais tai paralēlais Plinšu kanāls. Dubna (arī Plinšu kanāls) plūst tālāk uz Ārdavu un pēc tam tālāk uz netālu esošo Leja ezeru. Sivers ir devītais lielākais Latvijas ezers pēc platības un piektais lielākais pēc ūdens tilpuma (Eipurs, 1998). Pēc oficiālajiem datiem ezera platība ir 1812,1 ha, ko sastāda 1759,0 ha ezera ūdensvirsas laukums un 53,1 ha salas (Eipurs, 1998). Pēc autora aprēķiniem, kas precizēti pēc jaunākajām ortofotokartēm un situācijas dabā, ezera šābrīža platība sastāda 1784,8 ha, ko aizṇem 1735,7 ha ezera ūdensvirsas laukums un 49,1 ha salas. Vispār Sivera platība diezgan būtiski mainās atkarībā no ūdenslīmeņa. Piemēram, B. Bērziṇš pēc stāvokḷa 1939. gadā ezera platību novērtēja uz 1744,1 ha, ko sastādīja 1692,1 ha ūdensvirsas platība un 52,0 ha salu platība (Bērziņšs, 1943). Savukārt pirms 1929. gadā notikušās Dubnas padziļināšanas, kas izraisīja ūdens līmeṇa pazemināšanos par 0,4 0,5 m, Sivera platība tika novērtēta uz 1874,2 ha, ko sastādīja 1864,1 ha ezera ūdensvirsa un 10,1 ha salas (Ozoliņ̌s, 1932; Glazačeva, 2004). Sivera ezera vidējais ūdens līmenis mūsdienās atrodas 159,2 m vjl. (PSRS GG̣KP 1971. gadā uzmērītā topogrāfiskā karte). Pēc 1929. gadā veiktās Dubnas gultnes padziļināšanas Sivera ezera ūdens līmenis, spriežot pēc krasta profila, pazeminājās par aptuveni 0,4 0,5 m (LVMPI, 1973; Glazačeva 2004). Ezera lielākais dziḷums ir 24,5 m (Rubinu bedre, latgaliski Rubynu dūbs jeb Jama), bet vidējais dziḷums - 6,3 m (Bērziņš, 1943). Ezera krasta līnijas garums pēc B. Bērziņa 1939. gada aprēḳiniem bija 53,20 km ar salām, bet bez salām - 38,98 km. Savukārt ezera lielākais garums bija 8,250 km, bet platums - 4,920 km (Bērziṇš, 1943). Latvijas Valsts Meliorācijas pētniecības institūta 1973. gadā savāktajos datos Siveram norādīts tāds pats krasta līnijas garums - 53,2 km, bet lielākais garums un platums nedaudz atšksiras, attiecīgi, 8,1 km un 5,0 km (LVMPI, 1973). Pēc autora precizētajām ziṇām ezera krasta līnijas garums ir 53,1 km, bez salām - 40,0 km, lielākais garums - 8,35 km un lielākais platums - 5,18 km. Ezera ūdens tilpums ir 106, 81 milj. m³ (Bērziņš, 1943). Ezerā ir 25 glaciālas izcelsmes salas ar kopējo platību 48,7 ha un viena 0,37 ha liela peldošā Diuṇis slīkšṇu sala (ar kokiem), kas attēlota jau 1952. gadā uzmērītajā kartē. Tātad, kopējais Sivera 
salu skaits mūsdienās ir 26 un to kopējā platība sastāda 49,1 ha. Nelielā sateces baseina dēl ezeram ir ilgs ūdens apmaiņas periods - 6,54 gadi, kas ir raksturīga pazīme daudziem Latvijas lobēliju-ezereņu ezeriem (www.ezeri.lv). Tik ilgs ūdens apmaiņas periods saistībā ar ezera labo ūdens kvalitāti un mūsu apstākḷos ievērojamo dzidrību, kā arī unikālajām biolog̣iskās daudzveidības vērtībām norāda, ka ezers un tā ekosistēma ir ḷoti jūtīga pret jebkāda veida piesārṇošanu.

Siveram ir ḷoti nelīdzena ezerdobe ar ḷoti daudziem sēkḷiem un daudzām dzelmēm. B. Bērziņ̌s savā pētījumā min 88 sēkḷus, bet vecie zvejnieki 1950. gados teikuši, ka Siverā ir pavisam 107 sēkḷi, ko iedala seklajos (līdz 2 m dziḷumam) un dziḷajos (dziḷāk par 2 m). Ezera centrālajā daḷā pēc B. Bērziņa sastādītās ezera dziḷumu kartes var saskaitīt 15 dzelmes, kuru dziḷums sniedzas no 14 līdz 24,5 m. Jāpiezīmē, ezera dziḷie sēkḷi ir galvenās zivju koncentrēšanās vietas. Ezeram raksturīga arī mūsu apstākḷiem ievērojama dzidrība, kas ezera centrālās daḷas vidū 2014. gada 18. septembrī bija 5,6 m. Salīdzinājumam arī blakusesošā Ārdava ūdens ir aptuveni tikpat dzidrs - 5,4 m (U. Suško, 7.8.2014.), bet Dridz̄̄ pat nedaudz dzidrāks - 6,5 m (centrālā daḷa, 8.5.2008.) (Bružika, 2008). Tas vairāk kā divas reizes pārsniedz Latvijas ezeru lielākajai daļai raksturīgos vidējos rādītājus (1,5 - 2,5 m) un ir ḷoti nozīmīgs reto un aizsargājamo ūdensaugu sugu ilgtspējīgas pastāvēšanas faktors. Vienlaicīgi tas liecina arī par labiem skābekḷa apstākḷiem, jo dzidram ūdenim ir raksturīgi labi skābekḷa apstākḷi, kas ir ḷoti nozīmīgi retu un apdraudētu dziḷūdens ezeru iemītnieku, piemēram, repša Coregonus albula un relikto vēzī̌su (piem., Eurytemora lacustris un Pallasea quadrispinosa) pastāvēšanai (Aleksejevs, Birzaks, 2012; Bērziņš, 1938a; Laganovska, 1957; Plikšs, Aleksejevs, 1998; Vadzis, 1969). Par šādu ūdens kvalitāti galvenokārt ir jāpateicas ievērojamai ezera ūdens krājumu atjaunotnei no gruntsūdeṇiem un salīdzinoši mazam ezera sateces baseinam ar nelielu ezerā ietekošo upīšu skaitu. Ezeram ir dzeltenīgi olīvzaḷa ūdens krāsa (U. Suško, 18.9.2014.) un tā krāsainība atbilst 24,0 - 27,5 Pt/Co vienībām (Jankēvica et al., 2012). Sal̄î̀ninājumam Ārdavā ūdens krāsainība ir aptuveni tāda pati - no 21,0 līdz 28 Pt/Co vienībām, bet Dridzī vēl mazāka - no 13,0 līdz 26,5 Pt/Co vienībām (Jankēvica et al., 2012). Sivera litorāla seklākajā daḷā līdz 1,5 - 2,0 (2,5) m dziḷumam izteikti dominē trīs veidu minerālgrunts substrāts - smilšains, oḷains un akmeṇains. Litorāla dziḷākajā daḷā (dziḷāk par 2,0 - 2,5 m) dominē dūṇaina minerālgrunts un dūṇaina grunts.Lielākie ezera litorālā sastopamie granīta laukakmeṇi sasniedz 2,0 m garumu, 1,5 m platumu un 1,5 m augstumu (Lielais jeb Gulāana akmens). Labās ūdens kvalitātes un repša Coregonus albula sastopamības dēl Sivers ir noteikts kā prioritāra lašveidīgo ūdenstilpe (MK noteikumi nr. 118). 
Apsekošanas rezultātā tika veikts visā Sivera izpētes teritorijā sastopamo Eiropas Savienības un Latvijas aizsargājamo biotopu detāls kartējums, kā rezultātā tika konstatēti 17 Eiropas Savienības aizsargājamie biotopi ar 28 variantiem un 21 Latvijas aizsargājamais biotops (t. sk. 3 Eiropas Savienībā un 7 Latvijāa aizsargājamie saldūdens biotopi), kas skaita ziṇā trīs līdz trīsarpus reizes pārsniedz blakus esošajā dabas parkā „Dridža ezers” zināmo šādu biotopu skaitu (5 Eiropas Savienības un 7 Latvijas aizsargājamie biotopi) (Bružika, 2008) no teritorijas kopējās platības. Kopējā Eiropas Savienības un Latvijas aizsargājamo biotopu platība Sivera izpētes teritorijā ir 2050,1 ha jeb 44,7\% no to kopplatības. Kopumā tika reǵistrēti 312 aizsargājamo biotopu poligoni, no kuriem 228 poligoni pārstāv savstarpēji atbilstošos Eiropas Savienības un Latvijas aizsargājamos biotopus, bet 84 poligoni - Sivera ezerā sastopamo Latvijas aizsargājamo biotopu „4.11. Neaizauguši plaši ezeru liedagi”. Tika konstatēts, ka Sivera ezers un tā apkārtējā teritorija ir īpaši nozīmīga kā divu Latvijā retu un sešu l,oti retu Eiropas Savienības aizsargājamo biotopu sastopamības vieta, kā kopējā platība sastāda 1786,7 ha jeb 39,0\% no izpētes teritorijas kopējās platības. Latvijā reti sastopamos aizsargājamos biotopus pārstāv „,6210/3.21. Sausi zālāji kaḷķainās augsnēs” un „6230*/3.22. Vilkakūlas zālāji”, kas kopā aizṇem 24,5 ha jeb 0,5\% no izpētes teritorijas kopējās platības, bet l,oti retos biotopus - „3130/4.2. Ezeri ar oligotrofām līdz mezotrofām augu sabiedrībām”, „,6120*/3.17. Smiltāju zālāji”, „,5130/1.7. Kadiķu audzes zālājos un virsājos”, „,6530*/3.20. Parkveida pḷavas un ganības”, „6410/3.23. Mitri zālāji periodiski izžūstošās augsnēs”, „9160/1.10. Ozolu meži', kā kopējā platība sastāda 1762,1 ha jeb 38,4\% no izpētes teritorijas kopējās platības.

Līdzīgā veidā visā izpētes teritorijā tika pētīta arī reto un aizsargājamo vaskulāro augu, sūnaugu, mieturaḷǵu un citu organismu grupu sugu izplatība. Izpētes rezultātā apsekotajā teritorijā tika konstatētas 39 retas un aizsargājamas sugas (1 sēṇu, 3 mieturaḷǵu, 11 sūnaugu un 24 vaskulāro augu sugas), kam kopumā tika reǵistrētas aptuveni 1400 atradnes. Šo sugu skaitā ietilpst 26 īpaši aizsargājamas sugas (1 sēṇu, 2 mieturaḷǵu, 7 sūnaugu un 16 vaskulāro augu sugas), 29 Latvijas Sarkanajā grāmatā iekḷautas sugas, 13 retas sugas (t. sk. 9 sugas Latvijas Sarkanajā grāmatā) un 7 mikroliegumu sugas. Desmit no šīm sugām ir iekḷautas Eiropas Savienības Sugu un biotopu direktīvā, t. sk. 6 sugas - spilvainais ancītis Agrimonia pilosa, Lapzemes āḳīte Hamatocaulis lapponicus, spīdīgā āḳīte H. vernicosus, Lēzeḷa lipare Liparis loeselii, lokanā najāda Najas flexilis un smalkā najāda $N$. tenuissima II un IV pielikumā, bet 4 sugas - apdzira Huperzia selago, zilganā baltsamtīte Leucobryum glaucum, gada staipeknis Lycopodium annotinum un vālīšu staipeknis L. clavatum - V pielikumā. 
Septiṇpadsmit no retajām un aizsargājamajām augu sugām konstatētas Siverā, bet 22 sugas - ezeru krastos. Sivera izpētes teritorijā konstatētais reto un aizsargājamo augu sugu skaits vairāk kā trīs reizes pārsniedz blakus esošajā dabas parkā „Dridža ezers” konstatēto šādu sugu skaitu (12 sugas) (Bružika, 2008).

Sivers ir ar̄̄ zināms kā Latvijā un Eiropā aizsargājamā repša Coregonus albula (iekḷauts Eiropā Sugu un biotopu direktīvas V pielikumā) un Latvijā retās ezera salakas (sṇitkas, sņatas, sniedzes) Osmerus eperlanus spirinchus sastopamības vieta (Aleksejevs, Birzaks, 2012; Plikšs, Aleksejevs, 1998). Repša populāciju stāvoklis pēdējās desmitgadēs notikušās ezera eitrofikācijas dēḷ ir būtiski pasliktinājies un tās lielums ievērojami sarucis, bet ezera salaka pēc vietējo zvejnieku ziṇām pēdējo reizi reǵistrēta pirms aptuveni 15 gadiem. Papildus šīm sugām Sivera ezerā agrākos gados hidrobiologu B. Bērziņa un Z. Spura veikto pētījumu rezultātā konstatētas arī 9 retas un aizsargājamas spāru sugas, no kurām sešas sugas ir aizsargājamas - karaliskā dižspāre Aeshna imperator, raibgalvas purvspāre Leucorrhinia albifrons, resnvēdera purvspāre Leucorrhinia caudalis, spilgtā purvspāre Leucorrhinia pectoralis, main̄̄gā spāre Libellula fulva, zaļganā zaigspāre Libellula fulva, sešas sugas ir iekḷautas Latvijas Sarkanajā grāmatā - dienvidu dižspāre Aeshna mixta, karaliskā dižspāre Aeshna imperator, rudā dižspāre Aeshna isoceles, brūnganā plankumspāre Epitheca bimaculata, mainīgā spāre Libellula fulva, zalıganā zaigspāre Libellula fulva, bet trīs sugas - Eiropas Savienības Sugu un biotopu direktīvā, t. sk. viena suga II un IV pielikumā - spilgtā purvspāre Leucorrhinia pectoralis un divas sugas IV pielikumā - raibgalvas purvspāre Leucorrhinia albifrons, resnvēdera purvspāre L. caudalis (Bērziņš, 1938b, 1942; Spuris, 1953, 1954, 1956, Andrušaitis, 1998).

Visretākās no Siverā un tā apkārtnē konstatējām vaskulāro augu un sūnaugu sugām ir smalkā najāda Najas tenuissima, lokanā najāda N. flexilis, Lapzemes āḳīte Hamatocaulis lapponicus, vienzieda krastene Littorella uniflora, ūdens subulārija Subularia aquatica un pḷavas avoksne Philonotis marchica. Pasaules mēroga retums ir smalkā najāda Najas tenuissima, kas visā pasaulē ir zināma tikai aptuveni 25 vietās (Suško, 2008). Sivers ir šīs sugas otra zināmā atradne Latvijā un Baltijas valstīs. Suga Siverā tika atklāta pirmo reizi un ir konstatēta 28 atradnēs. Faktiskais tās atradņu skaits ir jāreizina vismaz ar divi, jo 2 m dziḷumā praktiski nav iespējams apsekot tik lielu platību. Pēc smalkās najādas populācijas lieluma Sivers ir uzskatāms par bagātāko šīs sugas atradni pasaulē. Eiropas mēroga retums ir lokanā najāda Najas flexilis, kas Eiropas Savienības kontinentālajā daḷā kopā ar Norvēǵiju un 
Šveici ir zināma arī tikai aptuveni 25 vietās. Š̄̄ suga Siverā tika konstatēta 34 atradnēs. Faktiskais tās atradņu skaits arī ir jāreizina vismaz ar divi, jo 2 m dziḷumā praktiski nav iespējams apsekot tik lielu platību. Pēc lokanās najādas populācijas lieluma Sivers ir uzskatāms par bagātāko š̄is sugas atradni Eiropas Savienības kontinentālajā daḷā kopā ar Norvēǵiju un Šveici. Trešais īpašais Eiropas Savienības un Baltijas līmeņa retums, kas atrasts Sivera izpētes teritorijāa, ir Lapzemes āķīte Hamatocaulis lapponicus. Šī reliktā ziemeḷu suga no Baltijas valstīm zināma vienīgi Latvijā un Igaunijā (1 atradne) un šobrīd pie mums sastopama tikai 6 mazu ezeriṇu litorālā vai krastos. Eiropas Savienībā vēl š̄ suga ir ļoti reti sastopama Zviedrijā, bet reti - Somijā. Sivers ir bagātākā vienzieda krastenes Littorella uniflora atradne Baltijā, kur mūsdienās ir saglabājušās tikai 10 - 13 atradnes Latvijā un 2 - 3 atradnes Igaunijā. Siverā sastopamā vienzieda krastenes populācija vismaz 10 - 20 reizes pārsniedz visu pārējo Baltijā zināmo krastenes populāciju kopējo lielumu. Ūdens subulārijai Subularia aquatica Sivers šobrīd ir viena no dažām vēl zināmajām atradnēm Latvijā un Baltijā, kas turklāt ir ļoti bagāta un vitāla (subulārija atzīmēta 20 vietās). Sivers ir bagātākā ūdens subulārijas atradne visā Baltijā. Latvijā ḷoti reta suga ir arī plavas avoksne Philonotis marchica, kas ir zināma tikai dažās atradnēs un aug Sivera ezera nokrastes slīkšņās.

Najādu ziṇā Sivers ir uzskatāms par bagātāko un izcilāko najādu ezeru ne tikai Baltijas valstu mērogā, bet visā Eiropas Savienības kontinentālajā daḷā kopā ar Norvēǵiju un Šveici. Lobēliju-ezereņu kompleksa ziṇā Sivers ir bagātākais un izcilākais lobēliju-ezereṇu ezers visā Baltijā. Tas ir arī pēc platības lielākais Eiropas Savienības un Latvijas aizsargājamais biotops ,3130/4.2. Ezeri ar oligotrofām līdz mezotrofām augu sabiedrībām” Latvijā un Baltijā, kas aizṇem 1733,9 ha lielu platību (bez slēgtā un purvainā Diuṇis kokta līča) jeb 37,8\% no visas izpētes teritorijas platības, kā arī 84,6\% no Eiropas Savienības un Latvijas aizsargājamo biotopu kopējās platības šajā teritorijā.

Viens no galvenajiem Sivera unikālo dabas vērtību pastāvēšanas garantiem ir tā tīrais un dzidrais ūdens. Saglabājoties labai ūdens kvalitātei, saglabāsies arī ezera unikālās dabas vērtības. Pēdējo 85 gadu laikā Siverā un tā krastos notikušas vairākas to unikālās dabas vērtības apdraudošas darbības, kas ir būtiski veicinājušas ezera eitrofikāciju un ievērojami samazinājušas retajām un aizsargājamajām augu un dzīvnieku sugām piemēroto biotopu platības. Galvenās no tām - ūdens līmeṇa pazemināšana 1929. gadā, notekūdeņu ievadīšana ezerā no padomju laika fermām laika posmā starp 1965. un 1991. gadu, Būkštu purva noteces ūdeṇu ievadīšana Siverā ap 1965. gadu, aptuveni puses ezera apkārtējo 
platību nomeliorēšana laika posmā no 1960. līdz 2010. gadam. Mūsdienās nozīmīgākais ezeru piesārņojošais un tā unikālās dabas vērtības apdraudošais faktors ir biogēno elementu nokḷūšana ezerā pa meliorācijas sistēmām no intensīvi apsaimniekotām lauksaimniecības zemēm un zivju dīḳiem.

Lai saglabātu visā Eiropas mērogā unikālās, bet šobrīd nekādā juridiskā veidā neaizsargātās Sivera un Ārdava ezera ekosistēmas, pēc iespējas drīzākā laikā nepieciešams paplašināt dabas parka „Dridža ezers” teritoriju, iekḷaujot tajā abus minētos ezerus ar apkārtējo teritoriju, kā arī blakus esošo Leja ezeru (līdz dabas parka „Cārman,a ezers” robežai) ar līdzīgām zināmajām un potenciālajām dabas vērtībām. Paplašināto dabas parku „Dridža ezers”, kurā ietilptu arī dabas parks „Cārmaņa ezers” un dabas liegums „Ojatu ezers”, šādā skatījumā būtu nepieciešams pārdēvēt par Sauleskalna dabas parku. Vajadzības gadījumā šo paplašināto īpaši aizsargājamo teritoriju nākotnē varētu pārveidot arī par Sauleskalna nacionālo parku, kam tā pēc savām izcilajām dabas un nozīmīgajām kultūrvēsturiskajām vērtībām neapšaubāmi atbilst.

\section{Izmantotā literatūra:}

Andrušaitis G. (red.) 1998. Latvijas Sarkanā grāmata. Retās un apdraudētās augu un dzīvnieku sugas. Bezmugurkaulnieki. Rīga: LU Biologijas institūts, 4. sēj., 388.

Auniņš, A. (red.) 2013. Eiropas Savien̄̄bas aizsargājamie biotopi Latvijā. Noteikšanas rokasgrāmata. 2. papildināts izdevums. Rīga: Latvijas Dabas fonds un Vides aizsardzības un reǵionālās attīstības ministrija, 320.

Aleksejevs, E. ., Birzaks, J. 2012. The current state of Coregonidae in the lakes of Latvial Acta Biologica Universitatis Daugavpiliensis, Supplement 3:3-13.

Bērziņš, B. 1938a. Repša dzīve / Daba un zinātne. Rīga, 6:178-181.

Bērziņš, B. 1938b. Piezìmes par spārēm (Odonata)/ Daba un zinātne. Rīga, 6:186.

Bērziņš, B. 1942. Beitrag zur Kenntnis der Odonatenfauna Lettlands/ Folia Zoologica et Hydrobiologica. Rīga, 11(2):329-350.

Bērziņš, B. 1943. Die Morphometrie einiger Seen Lettlands/ Zinātniskie raksti. Matemātikas un dabas zinātņu fakultātes dabas zinātņu nodaḷas sērija. Rīga, 1(6):187-240.

Bružika, I. 2008. Dabas parka „Dridža ezers” dabas aizsardzības plāns laika periodam no 2009. līdz 2019. gadam. Daugavpils, 151. 
Eipurs, I. 1998. Sīvers/ Enciklopēdija „Latvijas daba”. Rīga, 5:102-103.

Glazačeva, L. 2004. Latvijas ezeri un ūdenskrātuves. Jelgava, 176.

Jankēvica, M., Šīre, J., Kokorīte, I., Kḷaviņš, M. 2012. Assesment of the sediment chemical quality in salmonid lakes in Latvia. Acta Biologica Universitatis Daugavpiliensis, Supplement 3:36-49.

Laganovska, R. 1957. Latvijas PSR ezeru repsis - Coregonus albula (L.) un tā biologijal Latvijas PSR ZA Vēstis. Rīga, 3(116):83-95.

Ozoliņ̌s, V. 1932. Latvijas ezeru skaits un platība. Folia Zoologica et Hydrobiologica. Rīga, IV(1):61-67.

Latvijas Valsts Meliorācijas pētniecības institūta (LVMPI) Sivera apsekojuma materiāli, 1973. Rīga.

Plikšs, M., Aleksejevs, Ē. 1998. Latvijas daba. Zivis. Rīga (Gandrs), 304.

PSRS Ministru padomes Galvenās ǵeodēzijas un kartogrāfijas pārvaldes 1 : 10000 mēroga kartes, 1976 (1971. g. uzmērījums).

Spuris, Z. 1953. Par Latvijas PSR ezeru pamatbiotopu svarīgākajām dzīvnieku sugām un to izplati/ Latvijas PSR ZA Vēstis. Rīga, 9(74):67-82.

Spuris, Z. 1954. Dažas Latvijas PSR dienvidaustrumu ezeru faunas īpatnības/ Latvijas PSR ZA Vēstis. Rīga, 3(80):79-84.

Spuris, Z. 1956. Strekozi Latvijskoj SSR (Стрекозы Латвийской CCP). Rīga, 96.

Suško, U. 2008. Najas tenuissima - a new macrophyte species in flora of the Baltic Countries/ Botanica Lithuanica, 14(1):65-67.

Suško, U. 2013. Ārdava ezera un tā apkārtējās teritorijas dabas vērtību raksturojums saistībā ar smalkās najādas Najas tenuissima populācijas saglabāšanu tagad un nākotnē. Rīga, 72.

Vadzis, Dz. 1969. Reliktās sānpeldes (Pallasea quadrispinosa) izplatība Latvijas PSR ezeros un tās zivsaimnieciskā nozīmel Latvijas PSR ZA Vēstis. Rīga, 5(262):80-85.

www.ezeri.lv - biedrības „Latvijas ezeri” portāls. 


\title{
PELDOŠĀ MONITORINGA STACIJA KĀ PAMATS PASTĀVĪGAM HIDROBIOLOĢISKAJAM UN HIDROĶĪMISKAJAM MONITORINGAM ENGURES EZERĀ
}

\author{
Roberts ŠILIN̦Š \\ Engures ezera dabas parka fonds \\ *e-pasts:eedp@inbox.lv
}

Engures ezera hidrobioloğiskās un hidroḳīmiskās īpatnības saistītas ar ezera izcelsmi - tas ir lagūnas tipa caurtekošs morfometriski eitrofs ezers, kura vidējais dziḷums nepārsniedz $0.5 \mathrm{~m}$. Engures ezera sedimenti kopumā ir viendabīgi - pamatā smalka, dūņaina smilts, kas sajaucas ar kalı̣ainiem hāru nogulumiem. Ļoti svarīgs ezera kā hidroekosistēmas komponents ir mieturalıgeses, kas palīdz uzturēt ezera dzidrūdens stāvokli. Pagājušā gadsimta 90. gadu sākumā ievērojamās platībās mieturaḷgés iznīkušas, atklājot dūṇas, vai arī to vietu aizṇēmuši dažādi iegremdētie ūdens augi (glīvenes Potamogeton spp., iegrimusī raglape Ceratophyllum demersum, parastie elši Stratoites aloides), kas liecina par paaugstinātu piesārṇojumu ar biogēnajiem elementiem.

Engures ezera hidroekosistēma, tās struktūra un īpatnības galvenokārt ir pētìtas vasaras veǵetācijas periodā (Sprinğge et al. 2000, Briede et al. 2000, Spriṇge et al. 2007, Sprinǵge et al. 2011). Lai gūtu pilnīgāku priekšstatu par hidroķīmisko parametru izmaiņām Engures ezerā visā bezledus periodā sasaistot tās ar metereologisko parametru izmaiṇām un ar mērḳi turpināt jau iepriekš veiktos pētījumus 2014. gada rudenī ES LIFE fonda finansētā projekta LIFE COASTLAKE ietvaros tika uzbūvēta peldoša monitoringa stacija, kas tiks līdz 2015. gada pavasarim aprīkota ar DAVIS meteostaciju, kas veiks pastāvīgus metereolog̣isko parametru - gaisa temperatūras, atmosfēras spiediena, vēja stipruma un virziena mērījumus divas reizes diennaktī. Ūdens hidrokīimisko parametru mērīšanai uz monitoringa platformas tiks uzstādīta HANNA multiparametru zonde, kura tāpat kā meteostacija divas reizes diennaktī veiks ūdens hidroḳīmisko parametru - temperatūras, ph, $\mathrm{O}_{2}$, nitrātu, elektrovadītspējas, duḷ̦ainības un sāḷuma mērījumus. Papildus šiem agregātiem plānots uzstādīt arī automātisko ūdens līmeṇa mērītāju, kas reizi diennaktī veiks ūdens līmeņa mērījumus. Visi iegūtie dati tiks uzkrāti datu logerī, no kura tie tālāk ar modēma palīdzību tiks nosūtîti uz datoru. Monitoringa stacija tiks novietota ezera centrālajā daḷā blakus jūraskraukḷu Phalacrocorax carbo kolonijai, bet to būs iespējams arī pārvietot uz jebkuru citu vietu ezerā ar motorlaivas palīdzību. Stacijas izveide 
palīdzēs uzsākt ilglaicīgu pastāvīgu jūraskraukḷu koloniju ietekmes novērtējumu uz ezera hidroḳīmisko parametru izmaiņām un izvērtēt to lomu barības vielu ienesē Engures ezerā, jo šie putni pamatā barojas ārpus ezera Rīgas jūras līcī. Jūraskraukḷu kolonija šajā vietā pastāv jau piecus gadus, bet pēdējos divos gados ligzdojošo īpatņu skaits ir strauji pieaudzis, un tajā pašā laikā arī tika novērotas būtiskas makrofìtu veǵetācijas izmaiņas. Stacija ir apgādāta ar autonomu elektrības ǵeneratoru, kas nodrošina nepieciešamo strāvas jaudu stacijas apgaismojumam, aprīkojumam un apsildei. Turpmāk plānots uzstādīt arī saules baterijas, kas nodrošinātu stacijas aprīkojumu ar nepieciešamo strāvas jaudu gadījumos, kad netiek izmantots ǵenerators un akumulatora baterijas. Vienlaikus uz platformas varēs atrasties, strādāt un nakšṇot divi pētnieki. Paralēli hidroḳīmiskajiem un hidrobioloǵiskajiem pētījumiem būs iespēja staciju izmantot arī ornitolog̣isko pētījumu veikšanai.

\section{Izmantotā literatūra:}

Briede A., Klavins M., Rodinov V. 2000. Chemical composition of Lake Engures (Engure), Latvia. Proceedings of the Latvian Academy of Sciences, Vol. 54, Nr. 5/6, p. 160-163.

Sprinğge G., Druvietis I., Parele E. 2000. The plankton and benthos communities of the lagoon Lake Engures, Latvia. Proceedings of the Latvian Academy of Sciences., Vol. 54, No. 5/6: 164-169.

Sprinğge G., Briede A., Druvietis I., Grinberga L., Konošonoka I., Parele E., Rodinovs V., Skuja A. 2011. Long-term Development of the Hydroecosystem of the Lake Engure and its Influencing Factors. Scientific Journal of Riga Technical University. Environmental and Climate Technologies. DOI: 10.2478/v10145-0110034-y: Volume 7. 


\title{
MIR INDEKSA (MACROPHYTE INDEX FOR RIVERS) IZMANTOŠANA LATVIJAS UPJU EKOLOG̣ISKĀS KVALITĀTES NOTEIKŠANĀ
}

\author{
Linda UZULE \\ Latvijas Universitātes Ģeogrāfijas un Zemes zinātņu fakultāte \\ *e-pasts: uzule.linda@inbox.lv
}

Ūdens ekolog̣iskā stāvokḷa novērtěšanai Latvijas upēs līdz šim izmantoti dažāâdi makrofìtu indeksi: upju trofiju raksturojošie makrofitu indeksi (Mean Trophic Rank - MTR; Macrophytical Biological Index for Rivers - IBMR), kā arī saprobitātes indekss. Pamatojoties uz iepriekš veiktajiem pētîjumiem, (PROJEKTS, 2008; Konošonoka, Kokorīte, 2014) par labāko metodi ūdens kvalitātes noteikšanai pēc makrofìtiem, atzīta Polijā lietotā upju kvalitātes novērtēšanas metode, kuras pamatā ir MIR (Macrophyte Index for Rivers) (Szsoszkiewicz et al., 2010) indeksa aprēḳināšana. Šī metode balstîta uz Lielbritānijā izstrādātās standartmetodikas principiem (Holmes et al., 1999).

MIR indekss ir balstīts uz makrofitu sugu sastāvu un sastopamību. Tas tiek lietots, lai noteiktu tekošu ūdeņu eitrofikācijas pakāpi, un tiek aprēķināts pēc šādas formulas:

$$
M I R=\frac{\sum\left(L i^{*} W i^{*} P i\right)}{\sum\left(W i^{*} P i\right)} * 10
$$

$\mathrm{Li}$ - sugas trofijas pakāpe (trophic ranking score) $(1-10)$,

Wi - svērtā vērtība (weight value) (1-3),

$\mathrm{Pi}$ - sugas sastopamība (coverage) $(1-9)$.

Katrai indikatorsugai ir piešķirta trofijas pakāpe, kas var būt amplitūdā no 1 līdz 10 (1 piesārņotu ūdeņu sugas, 10 - tîru ūdeņu sugas). Katrai sugai ir piešķirta arī atbilstoša svērtā vērtība W, kas iekḷaujas skalā no 1 (eiribiontas sugas - sugas ar plašu tolerances spektru) līdz 3 (stenobiontas sugas - sugas ar l̦oti šauru toleranci).

Gaujas/Koivas projekta ietvaros (Gauja/Koiva, 2013), kurā viena no projekta sadaḷām tika veltīta upju ekoloǵiskās kvalitātes novērtēšanai par indikatororganismiem izmantojot makrofitus, tika pielietota modificēta Polijas upju novērtěšanas metode, kas adaptēta atbilstoši Igaunijas apstākḷiem. Ekologiskās kvalitātes novērtēšanai tika izmantots MIR indekss, kurā iekḷautas 93 indikatorsugas. Indikatorsugu saraksts nav identisks ar Polijas metodes indikatorsugu sarakstu. No saraksta iznemtas 
tās makrofìtu sugas, kas Igaunijā nav sastopamas, vairākām sugām izmainītas to bioindikatīvās vērtības, kā arī saraksts papildināts ar jaunām sugām.

Pētījumā izmantoti Latvijas Vides, ǵeolog̣ijas un meteorolog̣ijas centra (turpmāk tekstā LVG̣MC) 2006., 2007., 2008. un 2013. gada monitoringa dati par 294 novērojumu vietām upēs, kurās noteikts makrofìtu sugu sastāvs un sastopamība. Dati iegūti veǵetācijas sezonas laikā - jūnijā, jūlijā un augustā. 2006. gadā monitorings veikts 29 novērojumu vietās, 2007. gadā - 105 vietās, 2008. gadā - 91 vietā, bet 2013. gadā - 69 novērojumu vietās. Kopumā LVG̣MC no 2006. līidz 2013. gadam monitoringa ietvaros veicis makrofìtu novērojumus 17 ritrāla tipa mazu upju posmos (R1), 3 potamāla tipa maza upju posmos (R2), 102 ritrāla tipa vidēji lielu upju posmos (R3), 85 potamāla tipa vidēji lielu upju posmos (R4), 5 ritrāla tipa lielu upju posmos (R5) un 82 potamāla tipa lielu upju posmos (R6).

Lai pārbaudītu Igaunijā adaptētā MIR indeksa saistību ar eitrofikācijas spiediena rādītājiem un pamatotu š̄ indeksa piemērotību izmantošanai Latvijas upju kvalitātes vērtēšanā, tika veikta Pīrsona korelācijas analīze starp MIR indeksu un eitrofikācijas spiediena rādītājiem - $\mathrm{N}_{\mathrm{kop}}, \mathrm{P}_{\mathrm{kop}}, \mathrm{N}-\mathrm{NH}_{4}{ }^{+}, \mathrm{N}_{-}$ $\mathrm{NO}_{2}^{-}, \mathrm{N}_{-} \mathrm{NO}_{3}^{-}$un $\mathrm{P}-\mathrm{PO}_{4}{ }^{3-}$ (skat. 1. tabulu). MIR indekss uzrāda statistiski būtisku saistību ar visiem biogēnajiem elementiem, izṇemot $\mathrm{N}^{-\mathrm{NH}_{4}}{ }^{+}$. Pīrsona korelācijas analīze veikta programmā IBM SPSS Statistics 22.

1. tabula. Pīrsona korelācijas koeficienti starp MIR indeksu un eitrofikācijas spiediena rādītājiem.

\begin{tabular}{|c|c|c|c|c|c|c|c|}
\hline & MIR & $\mathrm{P}_{\text {kop }}$ & $\mathrm{N}_{\text {kop }}$ & $\mathrm{N}-\mathrm{NH}_{4}{ }^{+}$ & $\mathrm{N}-\mathrm{NO}_{2}^{-}$ & $\mathrm{N}^{-\mathrm{NO}_{3}}{ }^{-}$ & $\mathrm{P}-\mathrm{PO}_{4}{ }^{3-}$ \\
\hline MIR & 1 & & & & & & \\
\hline$P_{\text {kop }}$ &,$- 323^{* *}$ & 1 & & & & & \\
\hline $\mathrm{N}_{\mathrm{kop}}$ &,$- 301^{* *}$ &, $252^{* *}$ & 1 & & & & \\
\hline $\mathrm{N}-\mathrm{NH}_{4}{ }^{+}$ &,- 056 &, $371^{* * *}$ & ,014 & 1 & & & \\
\hline $\mathrm{N}-\mathrm{NO}_{2}^{-}$ &,$- 314^{* *}$ &, $415^{* *}$ &, $715^{* *}$ &, $327^{* *}$ & 1 & & \\
\hline $\mathrm{N}-\mathrm{NO}_{3}{ }^{-}$ &,$- 290^{* *}$ &, $225^{*}$ &, $986^{* *}$ &,- 045 &, $718^{* *}$ & 1 & \\
\hline $\mathrm{P}-\mathrm{PO}_{4}{ }^{3-}$ &,$- 412^{* *}$ &, $852^{* *}$ &, $352^{* *}$ &, $240^{* *}$ &, $506^{* *}$ &, $337^{* *}$ & 1 \\
\hline
\end{tabular}

Korelācija būtiska pie ** $\mathrm{p}<0,01$

Korelācija būtiska pie * $\mathrm{p}<0,05$ 
Pēc veiktajiem pētījumiem un datu analīzes, Igaunijā adaptētais Polijas MIR indekss atzīstams par piemērotu Latvijas upju ekologiiskās kvalitātes noteikšanā. To apliecina veiktās statistiskās analīzes, kurās MIR indekss uzrāda statistiski būtiskas saistības ar $\mathrm{N}_{\text {kop }}, \mathrm{P}_{\text {kop }}, \mathrm{N}-\mathrm{NO}_{2}{ }^{-}, \mathrm{N}-\mathrm{NO}_{3}{ }^{-}$un $\mathrm{P}_{-} \mathrm{PO}_{4}{ }^{3-}$.

Lai varētu aprēḳināt MIR indeksu un līdz ar to noteikt upju ekoloǵisko stāvokli lielākam upju skaitam, lauka pētījumu laikā nepieciešams noteikt pēc iespējas visas upēs augošās makrofìtu sugas, kāa arī sugas būtiski noteikt līdz sugas līmenim nevis līdz ğints līmenim.

Atsevišķiem upju tipiem - R1 (ritrāla tipa mazas upes), R2 (potamāla tipa mazas upes), R5 (ritrāla tipa lielas upes) datu apjoms ir pārāk mazs, lai raksturotu tipam atbilstošo makrofìtu veǵetāciju. Nepieciešams papildināt LVG̣MC datu bāzi ar jaunām monitoringa vietām R1, R2 un R5 tipa upju posmos, lai iegūtu objektīvu vērtējumu par šo upju ekoloǵiskās kvalitātes novērtējumu, balstoties uz makrofìtu sastāvu un sastopamību.

\section{Izmantotā literatūra:}

Gauja/Koiva, 2013 (autoru kolektivs). Final report on assessment of the quality status of the transboundary water bodies (coastal, lakes, rivers) in Gauja/Koiva river basin district. Nepublicēts materiāls.

Holmes, N. T. H., Newman, J. R., Chadd, J. R., Rouen, K. J., Saint, L., Dawson, F. H. 1999. Mean Trophic Rank: A User's Manual. Research \& Development, Technical Report E38. Bristol, Environmental Agency.

Konošonoka, I., Kokorīte, I. 2014. Priekšlikumu izstrāde virszemes ūdeņu bioloǵiskās kvalitātes novērtēšanas metožu attīstībai. Rīga.

PROJEKTS 2008 „Virszemes ūden,u ekoloğiskās klasifikācijas sistēmas zinātniski pētnieciskā izstrāde atbilstoši Eiropas Parlamenta un Padomes Direktīvas 2000/60/EK (2000. gada 23. oktobris), ar ko izveido sistēmu Kopienas rīcībai ūdens resursu politikas jomā prasībām”. Tehniskā atskaite par 2008. gadu. LU 2009.

Szoszkiewicz, K., Zbierska, J., Jusik, S., Zgola, T. 2010. Metodyka badán terenowych makrofitów na potrzeby rutnowego monitoringu rzek (Macrophyte survey manual for the purpose of river monitoring). Bogucki Wydawnictwo Naukowe, Poznan. 


\title{
MAKROFĪTU VEĢETĀCIJAS RAKSTUROJUMS L̨OTI SEKLOS UN SEKLOS BRŪNŪDENS EZEROS LATVIJĀ
}

\author{
Lauma VIZULE - KAHOVSKA \\ Latvijas Vides, geologijas un meteorologijas centrs, Iekšzemes ūdeņu nodaḷa \\ *e-pasts: lauma.vizule-kahovska@lvgmc.lv
}

Saskaṇā ar Eiropas Parlamenta un Padomes Ūdens struktūrdirektīvu 2000/60/EC līdz 2015. gadam visos Eiropas Savienības dalībvalstu, tai skaitā Latvijas, ūdensobjektos ir jāsasniedz vismaz labs ūdeṇu ekoloǵiskais stāvoklis (European Comission, 2000). Galvenais pamats ūdeṇu ekoloǵiskā stāvokḷa novērtējumam ir ūdeṇu bioloǵiskā kvalitāte, bet makrofîti ir vieni no bioloǵiskās kvalitātes elementiem, kuri kā bioindikatori tiek izmanoti ūdeņu ekoloǵiskās kvalitātes noteikšanai (Penning et al., 2008), jo integrē informāciju par vides stāvokli vairāk kā viena veǵetācijas perioda garumā un atspogul,o to caur taksonomisko sastāvu un sastopamību (Schaumburg et al., 2004).

Pastāv dažāda ezeru klasifikācija, taču lai atbilstoši direktīvas 2000/60/EC prasībām novērtētu ūdensobjektu ekologisko kvalitāti, izmanto 10 ezeru ekologiskos tipus, kurus nosaka 19.10.2004. MK noteikumi Nr.858 „Noteikumi par virszemes ūdensobjektu tipu raksturojumu, klasifikāciju, kvalitātes kritēijiem un antropogēno slodžu noteikšanas kārtību”. Atbilstoši šai klasifikācijai Pērkonu, Sargovas, Babītes, Lielais Virānes ezers un Pakuḷu HES ūdenskrātuve ir ḷoti sekli brūnūdens ezeri ar augstu ūdens cietību, savukārt Viḷakas, Marinzejas, Audzeḷu, Juglas un Burtnieku ezers ir sekli brūnūdens ezeri ar augstu ūdens cietîbu.

Pētījumā tika izmantoti Latvijas Vides, ǵeolog̣ijas un meteoroloǵijas centra monitoringa dati par 2013. gadu.

Kopumā pētāmajos ezeros ir sastopami 52 augstāko ūdensaugu taksoni. Visbiežāk sastopamās sugas, kas tika konstatētas visos 10 pētāmajos ezeros, ir Nuphar lutea, Phragmites australis, Potamogeton perfoliatus un Scirpus lacustris. Visplašāk pārstāvētā - ar 8 sugām, ir glīveṇu dzimta Potamogetonaceae.

Pētāmajos ezeros tika konstatētas gan mezotrofiem, gan stipri eitrofiem ūdeniem raksturīgas sugas. Lielajā Virānes ezerā tika konstatēta Potamogeton praelongus, Burtnieku ezerā - Potamogeton gramineus, abas ir mezotrofu ūdeṇu indikatori. Babītes ezerā, Lielajā Virānes ezerā, Sargovas ezerā un 
Burtnieku ezerā ir sastopamas mieturalǵes Charophyceae - Chara spp. un Nitella sp. Vairākām Charophyceae dzimtas sugām ir augstas prasības pret ūdens kvalitāti, tādēl, to esamība norāda uz antropogēni maz ietekmētiem apstākḷiem. Savukārt Potamogeton pectinatus, kas atzīmējama kā izturīga pret stipru piesārṇojumu, kā arī eitrofiem ūdeṇiem raksturīgās Ceratophyllum demersum un Myriophyllum spicatum ir pret barības vielām prasīgas sugas, kas eitrofikācijas procesu rezultātā Eiropas ūdeņos ir nomainījušas lēni augošos izoetīdus un harofìtus (Sand - Jensen et al., 2000). Tomēr jāṇem vērā, ka ezers ir jāvērtē kompleksi - vienas indikatorsugas esamība nevar liecināt par mezotrofu vai tieši pretēji - hipereitrofu ezera stāvokli. Jāpiemin, ka Burtnieku un Marinzejas ezerā ir sastopama Latvijā invazīva suga Elodea canadensis.

Augstākais sugu skaits (26) tika novērots Pērkonu ezerā, savukārt zemākais - Sargovas ezerā (12) un Juglas ezerā (13). Svarīgi ir atzīmēt, ka zems sugu skaits ne vienmēr norāda uz pazeminātu ezera kvalitāti, jo vispārīgi sugu daudzveidība/bagātība ir augstāka mezotrofos un eitrofos apstākḷos, bet zemāka barības vielām nabadzīgos oligotrofos un distrofos, kā arī barības vielām pārbagātos hipereitrofos apstākḷlos (Penning et al., 2008).

Kopējais makrofìtu sugu skaita sadalījums pētāmajos ezeros atbilstoši Arber (1920) un Sculthorpe (1967) klasifikācijai, kas balstīta uz makrofītu piestiprināšanās veidu (Wetzel, 1983), ir sekojošs - virsūdens makrofīti (22 sugas), iegrimušie makrofīti (19), brīvi peldošie makrofïti (7) un peldlapu makrofìti (4). Visbiežāk sastopamie virsūdens makrofīti ir Phragmites australis un Scirpus lacustris, iegrimušie makrofìti - Potamogeton perfoliatus un Potamogeton lucens, brīvi peldošie makrofìti - Hydrocharis morsus - ranae un Ceratophyllum demersum, peldlapu makrofiti - Nuphar lutea un Nymphaea candida.

Vairumā gadījumu, izṇemot Babītes, Lielajā Virānes un Juglas ezerā, pēc sugu skaita dominējošais ezerā ir virsūdens makrofìtu augājs, kas veido apmēram pusi no kopējā ezera sugu skaita. Procentuāli lielākais virsūdens makrofìtu sugu skaits ( $71 \%$ no kopējā sugu skaita), tika konstatēts Audzeḷu ezerā. Iegrimušo un virsūdens makrofītu sugu skaita attiecība ir līdzīga Babītes ezerā (attiecīgi $33 \%$ un 29\%), Burtnieku ezerā (38\% un 42\%) un Juglas ezerā (38\% un 23\%), bet Lielajā Virānes ezerā pēc sugu skaita dominē iegrimušie augi, kas veido 53\% no kopējā sugu skaita ezerā. Savukārt Babītes ezerā un Juglas ezerā, salīdzinoši ar pārējiem ezeriem, ir procentuāli lielāks brīvi peldošo makrofìtu sugu skaits (attiecīgi 29\% un 23\%). Jāatzīmē, ka makrofītu ekomorfoloǵisko grupu sastopamība norāda 
arī uz ezera stāvokli. Eitrofiem ūdeņiem ir raksturīgas blīvas brīvi peldošo augu audzes, ko veido, piemēram, Ceratophyllum demersum, Lemna minor, Spirodela polyrhiza.

Maksimālais makrofìtu sastopamības dziḷums svārstās no 0,5 līdz 3 m ḷoti seklos ezeros, un no 0,8 līdz 3 m seklos ezeros. Vidējais maksimālais makrofìtu sastopamības dziḷums ḷoti seklos ezeros ir 1,6 m un seklos ezeros - 1,8 m, bet iegrimušo makrofìtu sastopamības dziḷums - 1,4 m l,oti seklos ezeros un 1,6 m seklos ezeros. Kaut arī iegrimušie makrofîti parasti ir visdziḷāk sastopamā makrofìtu grupa, zemais iegrimušo makrofìtu skaits un zemāks sastopamības dziḷums kā makrofītu veǵetācijai kopumā, pētāmajos ezeros ir likumsakarīgs. Makrofītu eksistence ir primāri atkarīga no minimālajām prasībām pret gaismu, tādēḷ gaismas pieejamība ir viens no galvenajiem limitējošiem faktoriem, kas nosaka makrofìtu izplatību dziḷumā (Sand-Jensen, Madsen, 1991). Brūnūdens ezeros humusvielas samazina gaismas iespiešanās efektivitāti, līdz ar to samazinās ūdens caurredzamību, kas savukārt samazina gaismas pieejamību iegrimušajiem makrofïtiem (Kirk, 1994).

Maksimālais dziļums, kādā ir sastopami iegrimušie makrofîti, ir 3 m - Sargovas, Burtnieku un Lielajā Virānes ezerā. Burtnieku ezerā un Sargovas ezerā visdziḷāk sastopamā suga ir Potamogeton lucens, bet Lielajā Virānes ezerā - mieturalı́ges Chara sp. un Nitella sp., kā arī Potamogeton pectinatus. Makroskopiskajām aḷgèm līdzās ūdens sūnaugiem ir vismazākās prasības pret gaismas daudzumu (Markarger, Middelboe, 1997), tādēḷ tie visbiežāk ir visdziḷāk sastopamie augi.

\section{Izmantotā literatūra:}

European Commission. 2000. Directive of the European Parliamentand of the Council 2000/60/EC establishing a framework for community action in the field of water policy. European Commission PE-CONS 3639/1/00 REV 1, Luxembourg.

Kirk, J.T.O. 1994. Light and Photosynthesis in Aquatic Ecosystems, Second Edition, Cambridge Univiersity Press.

Markarger, S., Middelboe, A. L. 1997. Depth limits and minimum light requirements of freshwater macrophytes. Freshwater Biology. 37, 553-568.

Penning, E., Dudley, B., Mjelde, M., Hellsten, S., Hanganu, J., Kolada, A., Van Den Berg, M., Poikane, S., Phillips, G., Willby, N., Ecke, F. 2008. Using aquatic macrophyte community indices to define the ecological status of European lakes. Aquatic Ecology. 42, 253 - 264. 
Sand - Jensen, K., Madsen, T.V. 1991. Minimum light requirements of sumberged freshwater macrophytes in laboratory growth eksperiments. Journal of Ecology.79:749 - 764.

Sand - Jensen, K., Riis, T., Vestergaard, O., Larsen, S.E. 2000. Macrophyte decline in Danish lakes and streams over the past 100 years. Journal of Ecology. 88, 1030 - 1040

Schaumburg, J., Schranz, C., Hofmann, G., Stelzer, D., Schneider, S., Schmedtje, U. 2004. Macrophytes and phytobenthos as indicators of ecological status in German lakes - a contribution to the implementation of the Water Framework Directive. Limnologica, 34, 302-314.

Wetzel, R. G. 1983. Limnology, 2nd Edition. Saunders College Publishing. 


\section{ATLANTIJAS STORES (ACIPENSER OXYRINCHUS) RESURSU PAPILDINĀŠANAS REZULTĀTI PIRMAJĀ GADĀ PĒC IZLAIŠANAS}

Mārcis ZIN̦ĢIS ${ }^{1 *}$, Ruta MEDNE ${ }^{1,2}$, Santa PURVIN̦A ${ }^{1}$

${ }^{l}$ Pārtikas drošības, dzīvnieku veselības un vides zinātniskais institūts „,BIOR”, Zivju resursu pētniecības departaments, Daugavgrīvas iela 8, Rīga, LV-1007, Latvija

${ }^{2}$ Latvijas Lauksaimniecības Universitāte, Veterinārmedicīnas fakultāte, Helmaña iela 8, LV-3004, Latvija

*e-pasts: marcis.zingis@bior.lv

\section{Ievads}

Store ir anadromā (migrējošā) zivju suga, kura bieži bija sastopama Baltijas jūrā un Baltijas reǵiona valstu upēs līdz 19.gs. beigām. Antropogēnās ietekmes rezultātā Eiropas upes un piekrastes ūdeņi, gandrīz zaudēja šo vērtīgo zivju sugu. Atlantijas stores (Acipenser oxyrinchus spp. oxyrinchus, Mitchill, 1815) izzušanas cēloṇi bija gan lielā nozveja, gan arī industriālā revolūcija, kam sekoja vides piesārṇojums un dabisko nārsta vietu nepieejamība sakarā ar hidroelektrostaciju dambju būvniecību un upju gultņu pārveidošanu (.Nordheim, 2002; Kirschbaum, 2002).

Šai sugai Baltijas reǵionā pašreprodukcijas iespējas ir ļoti zemas. Tāpēc ir nepieciešama tās mākslīga pavairošana, audzēšana un izlaišana, jo tikai šādā veidā būs iespējama iespēju robežas ātra un veiksmīga dabisko storu resursu atjaunošana (Kirschbaum, 2002; Gessner, u.c., 2007).

Vairāk, kā pirms 15 gadiem storu aizsardzība un resursu pavairošana Eiropā ir kḷuvusi par svarīgu starptautisku jautājumu. Pirmās valstis darbu pie Baltijas jūras storu pavairošanas ir veikušas Vācija un Polija, kas jau no 2006. gada ir uzsākušas storu mazuḷu ielaišanu dabiskajās ūdenskrātuvēs Vislā un Odrā (Gessner, 2007). Vēlāk storu dabisko resursu krājumu pavairošanā iesaistìjās Lietuva, ielaižot zivju mazuḷus Nemunas upes baseinā (Pilinkovskij, u.c., 2014).

Pārtikas drošības, dzīvnieku veselības un vides zinātniskais institūts "BIOR" storu resursu papildināšanu uzsāka 2013. gadā.

\section{Materiāls un metodika}

Lai 2013. gadā izlaistu storu divvasaru mazuļus, 2012. gada vasarā institūta zivju audzētava "Tome" iegādājās divarpus mēnešu vecus mazuḷus ar vidējo svaru 1,7g, bet otrajā gadā (2013.) divu nedēḷu vecus mazuḷus ar vidējo svaru $0,2 \mathrm{~g}$. Iegādātie storu mazuḷi bija pilnībā pārgājuši uz eksogēno 
barošanos, un to ēdināšanai tika izmantota komerciāli ražotā barība storēm, izvēloties vecumam atbilstošu granulu izmēru un barības daudzumu.

Zivis tika audzētas baseinos caurplūdes sistēmā, izmantojot Daugavas ūdeni, kas iegūts no Ķeguma HES ūdenskrātuves. Ūdens temperatūras režīma sezonālās svārstības bija no $22^{\circ} \mathrm{C}$ jūlijā līdz $10{ }^{\circ} \mathrm{C}$ oktobrī. Kad ūdens temperatūra pazeminājās $1 \overline{1} \mathrm{dz} 10^{\circ} \mathrm{C}$, zivis tika pārvietotas uz audzēšanas baseiniem recirkulācijas sistēmā, kur izmanto ūdeni no Sprinčupes avotiem. Minētajā audzēšanas sistēmā ūdens temperatūra visu ziemu svārstās no 8 līdz $10^{\circ} \mathrm{C}$. Pavasarī, kad Daugavā ūdens sasila līdz

$10^{\circ} \mathrm{C}$, storu mazuḷus pārvietoja atpakaḷ uz caurplūdes audzēšanas sistēmu. Šāds temperatūras režīms ziemošanas periodā tika piemērots tikai pirmajā audzēšanas gadā, nākamajos gados, tās tiek audzētas dabiskā temperatūras režīmā, kurš ziemā pazeminās līdz $0,3{ }^{\circ} \mathrm{C}$.

Iezīmēto storu migrāciju izpēte ir balstīta uz zīmīšu atguvumu analīzi. Informācija par iezīmētajām zivīm (svars, garums, nozvejas vieta, zīmītes numurs) tika saņemta no zvejniekiem. Gadījumos, ja store zvejas rīkos bija dzīva, tā tika atlaista.

\section{Rezultāti}

Pirmajā gadā pēc zivju ielaišanas tika saņemta informācija par 71 stores noķeršanas gadījumu, kas ir 4,73\% no visām pirmajā gadā ielaistajām iezīmētajām zivīm. Analizējot pirmajā gadā iegūto informāciju, redzams, ka pirmajās dienās pēc ielaišanas daḷa storu mazuḷu aizpeldēja pret straumi uz Daugavas Rīgas HES aizsprostu (1. att.), pārējās stores kādu laiku uzturējās izlaišanas vietā vai devās uz jūru. 


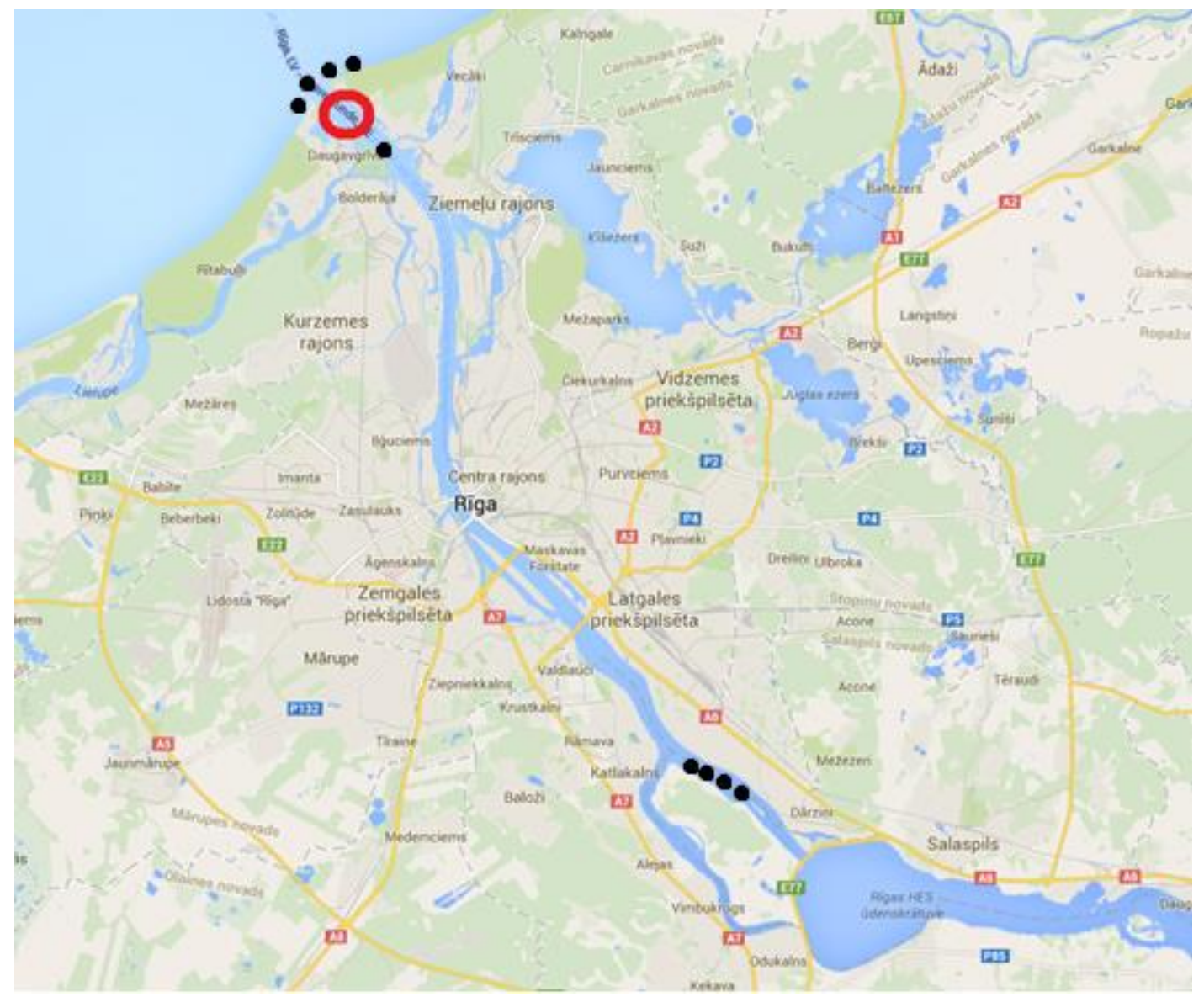

1. attēls. Storu noķeršanas vietas pirmajos mēnešos pēc to izlaišanas (2013. gada septembris, oktobris). Aplis - izlaišanas vieta; punkti - storu noḳeršanas vietas.

Ziemas periodā (novembris-februāris) informācija par noķeršanas gadījumiem netika saṇemta, kas ir izskaidrojams ar zvejas aktivitāšu samazināšanos.

Ziemā storu mazuḷi bija atstājuši Daugavu un jau martā un aprīlī bija sasnieguši Saulkrastus, Salacgrīvu un pat Pērnavas līci. 2014. gada vasarā saṇemtā informācija liecināja par to, ka stores pamatā izplatîjušās Rīgas jūras līča austrumu piekrastē līdz Pērnavas līcim, rietumu piekrastē līdz Kolkai, kā arī ziemeḷos starp Sāremā un Hījumā salām (2.att.). Pirmajā gadā pēc izlaišanas 95,8\% storu palika Rīgas jūras līcī un 4,2\% bija izgājuši ārpus tā, galvenokārt ziemeḷu virzienā. 


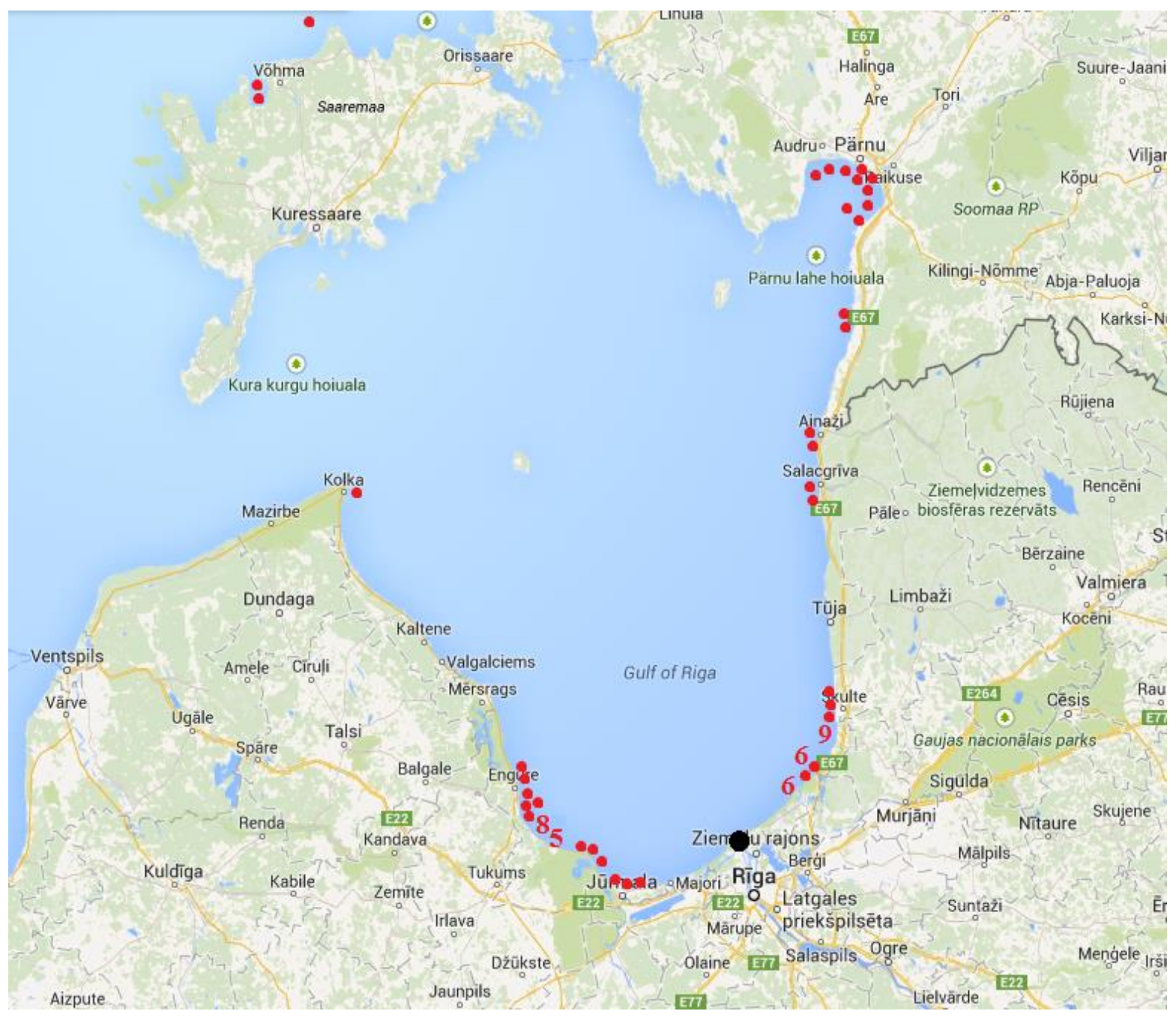

2. attēls. Storu noķeršanas vietas pirmajā gadā pēc to izlaišanas. 


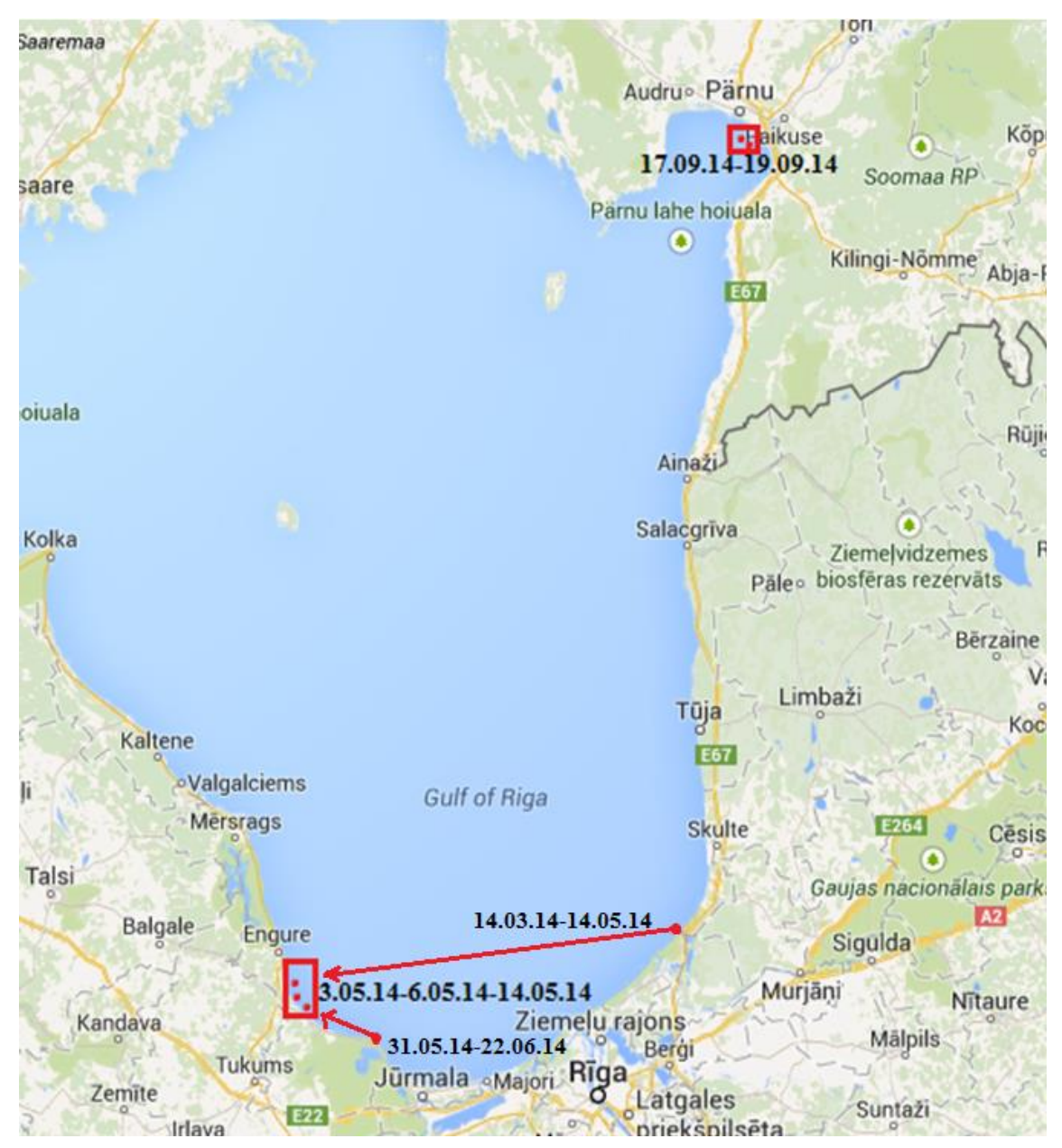

3.attēls. Atkārtoti vienas zivs noḳeršanas gadījumi.

Pirmā gada zīmīšu atguvumi norāda, ka stores neveic tālas migrācijas, bet pārvietojas no viena barošanās apvidus uz nākamo. To apstiprina četri storu atkārtotie noḳeršanas gadījumi (3. att.). Trijos gadījumos viena un tā pati store tika noḳerta divas reizes, bet vienā gadījumā trīs reizes ar dažādiem laika intervāliem: no divām dienām līdz diviem mēnešiem starp abām nozvejām (3.att.).

Vienā gadījumā store tika noḳerta austrumos no izlaišanas vietas, bet atkārtoti pēc diviem mēnešiem tika noḳerta rietumos, kas liecina par iespējamiem barošanās areāla meklējumiem tuvākajā apkārtnē neatkarīgi no virziena.

Izlaisto zivju vidējais svars bija $250 \mathrm{~g}$, pēc saņemtās informācijas to svars bija pieaudzis no 450 g līdz 960 g. Zivju svara pieaugums 2-4 reizes liecina par labu barības bāzi dabiskos ūdeņos un to, ka stores ir labi piemērojušās vietējiem apstākḷiem. No visiem noḳeršanas gadījumiem 38 stores tika 
atlaistas (54\%), 25 gadījumos tās gāja bojā zvejas rīkos (35\%) un 8 gadījumos to liktenis palika nezināms.

Otrajā gadā ielaisto storu mazuḷu daḷa pirmajā mēnesī līdzīgi kāa iepriekš pārvietojās pret straumi uz HES aizsprostu un dạ̣a izgāja jūrā. Divas zivis divas dienas pēc izlaišanas tika noķertas 30 km tālu no izlaišanas vietas Rīgas līcī pie Saulkrastiem (4. att.).

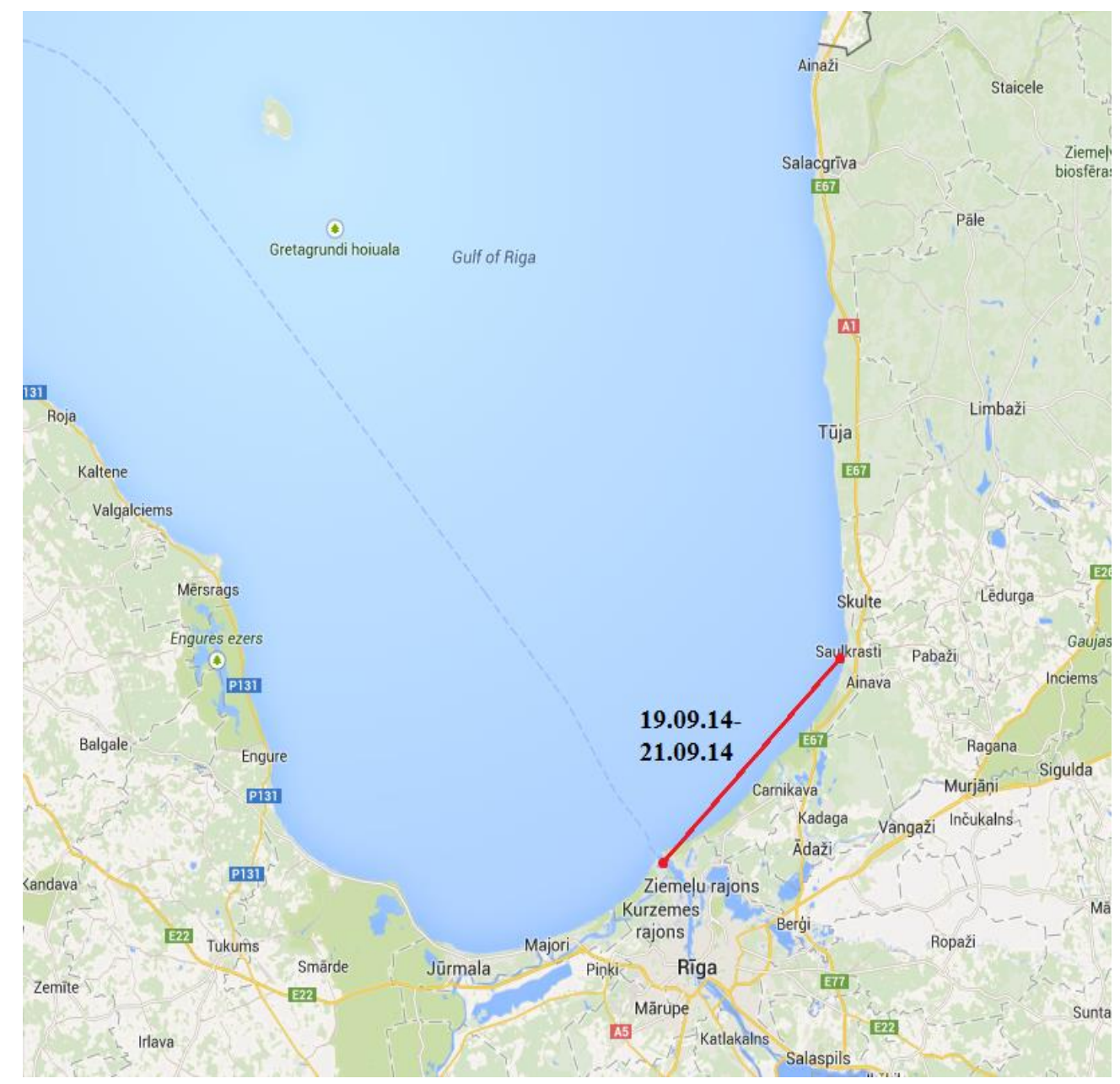

4. attēls. Divu storu migrācija pēc izlaišanas 17.09.2014.

\section{Secinājumi}

Pirmās dienas pēc ielaišanas stores pavada izlaišanas vietā vai migrē pret straumi līdz Rīgas HES aizsprostam, bet pirmo jūras gadu pavada Rīgas līcī.

Zivju svara pieaugums liecina par labu barības bāzi un veiksmīgu adaptāciju dabiskos ūden,os. 


\section{Izmantotā literatūra:}

Nordheim, H.v. 2002. International Workshop on Species Differentiation and Population Identification in the Sturgeons, Foreword.

Kirschbaum, F., Ludwig, A., Helsel, E., Wurtz, S., Kloas, W., Williot, P., Tiedemann, R., Arndt, G., Anders, E., Nordheim, H.v., Gessner, J. 2002. Status of the Project on Protection and Restoration of Atlantic Sturgeon in Germany.

Gessner, J., Arndt, G., Ludwig, A., Kirschbaum, F. 2007. Remediation of Atlantic Sturgeon in the Baltic Sea: Background, Status, and Perspectives.

Pilinkovskij, A., Butkauskas, D., Stakenas, S. 2014. Ecological and Genetic Monitoring of Sharp-nosed Sturgeon (Acipenser oxyrinchus Michill L.) Restoring Natural Population. 


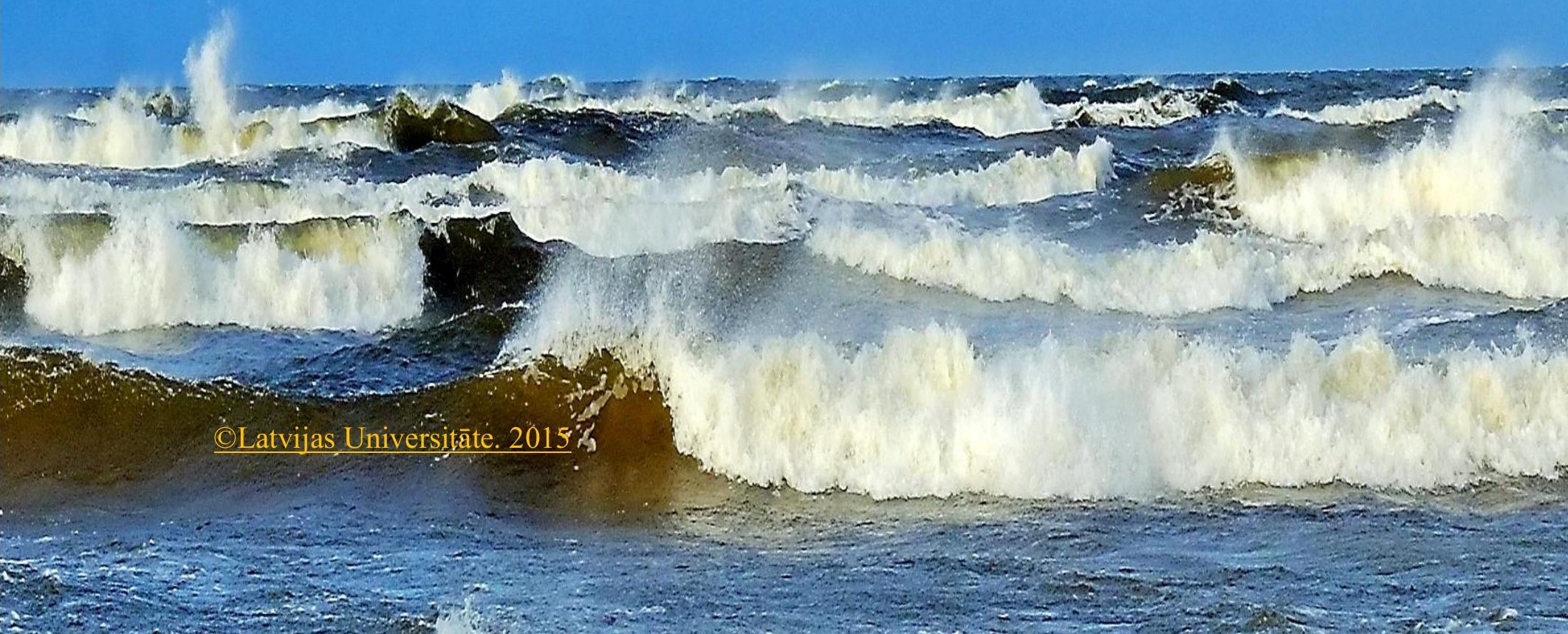

